\section{POSITIVE AND NEGATIVE} ASPECTS IN THE MANAGEMENT OF THE DACIAN FORTRESSES IN THE ORĀSTIIE MOUNTAINS LISTED AMONG UNESCO WORLD HERITAGE SITES

\begin{abstract}
The research and documenting of the historical monuments are fundamental and key tools for their adequate understanding and protection. Despite the numerous national and international laws, agreements and recommendations, regulating almost all aspects related to the protection of the monuments, they are not fully complied with and applied in Romania. The Dacian fortresses from the Orăștiei Mountains, on the list of UNESCO world heritage sites make no exception to the rule.

Recognition of the universal value of this fortified complex, formed of several fortresses, carried both prestige and responsibilities for Romania. The latter involved, among other, adequate legal frameworks, ensuring optimal conditions for the management, protection, restoration, research and highlight of these unique monuments that belong to the world heritage.

Romania counts among the 193 signatory states of the 1990 Convention for the protection of the World Cultural and Natural Heritage, adopted by UNESCO in 1972. Nevertheless, the effective enforcement of the Convention occurred only in 2000, when the government approved measures for the protection of the historical monuments on the World Heritage List.

After 2000, various laws on the management, preservation and protection of the monuments on the World heritage list were issued, nonetheless, there is sufficient space for improvement of the national regulatory framework, especially as regards the management of the cultural and natural heritage, the fight against archaeological poaching, the illegal traffic of antiquities etc., all of the above with impact also on the Dacian fortresses on the World Heritage list. Some of the provisions of these laws have not been applied or complied with, which made that some of the Dacian fortresses not to have a legal administrator, further resulting in the monuments decay.

To date, there are no management plans for the six Dacian fortresses. To this lack of management plans adds the lack of managers for these monuments, but also the lack of management plans and minimal short-term strategies that would solve stringent issues.

Another issue that the Romanian authorities failed to resolve is related to the permanent security of the monuments. The only Dacian fortress from the Orăștiei Mountains to benefit from 24/24-security services is Sarmizegetusa Regia, which is under the administration of the County Council of Hunedoara. Therefore, the phenomenon of the archaeological poaching and deliberate destruction disappeared completely in the area of Sarmizegetusa Regia. Not the same applies for the remaining fortresses, where the destruction, vandalism and archaeological poaching may be still found, and not rarely. In almost all these fortresses, there are buildings in ruin and walls dislodges on several parts. Access routes to some of these Dacian fortresses are inadequate, in some cases even difficult. Vegetation in these unmanaged sites has invaded the monuments, while significant parts of walls and buildings are covered
\end{abstract}

\section{Vitalie Bârcă}

Institute of Archaeology and Art History of Cluj-Napoca

vitalie_barca@yahoo.com

DOI: $10.14795 /$ j.v6i1.385

ISSN $2360-266 \mathrm{X}$

ISSN-L 2360 - 266X 
with layers of moss, lichens and bryophytes. The poor state of these fortresses is due to the fact they are managed by no one, although the County Council of Hunedoara has requested repeatedly the central authorities to transfer the management right of the other Dacian fortress in the county of Hunedoara, which was constantly refused.

For the lack of a manager and financial support, these monuments' risk for significant damage, with portions that might physically disappear over the course of time is very high, unless financial resources are allotted on a constant basis for preservation, restoration and protection.

Also, the legal status of the land on which the mentioned monuments lay and its registration was not clarified until now; the land mapping; the establishment of the holders of the ring to manage UNESCO remains; the inclusion of the monuments and protection areas in the PUZ (regional Urban Plan) and PUG (General Urban Plan) type documentations of the administrative-territorial units within the range of which lie respective monuments and documentation for the draft of large scale feasibility studies for each fortress were not prepared and drafted.

At Sarmizegetusa Regia, under the administration of the County Council of Hunedoara, things have changed for the better in the last six years, while discrepancies between this site and those unmanaged are increasingly more visible. There were set up the Administration of the historical monument of Sarmizegetusa Regia, constant security/surveillance, video surveillance, a Consulting Scientific Council was created and a regulation for visiting the site was drafted and enforced. There were established visiting routes and created explanatory panels with texts in Romanian and English for each monument, while in the pavilion from the access to the site may be purchased adequate informative materials. The access road to Sarmizegetusa Regia was asphalted, while at ca. $1 \mathrm{~km}$ from the entrance into the fortress was built a parking. The site is constantly attended and cleaned, regardless the season, thus reaching one of the standards that UNESCO monuments must comply. The County Council of Hunedoara also finances archaeological excavations, which led to the significant extension of the period when they are conducted, which led to outstanding results and impressive finds. A series of preservation works were also performed and the Day of Open Gates was set us as well.

Past all these positive things, there is a series of aspects that still require remedy. Amongst, the dislodgement of the constructional block and elements on certain parts of the fortification walls, the issue of the trees that fall onto the monument and lack of management plans.

The poor state in which lay part of these universal interest monuments reveals that the Romanian state, through the Ministry of Culture and National Identity, whose purpose, is among other, to protect the cultural heritage, shows nothing but contempt and total disinterest for these fortresses. The inactivity and lack of action of the state central authorities to which adds opposition in transferring the management of the fortresses left in ruin to other institutions is revolting and proves lack of vision, responsibility and respect for these unique monuments that belong to the universal heritage.

Keywords: heritage, monuments, UNESCO, Dacian fortresses, Orăștiei Mountains, Bănița, Costești-Blidaru, Costești-Cetățuie, Piatra Roșie, Sarmizegetusa Regia, Căpâlna

$\mathbf{I}$ $\mathrm{t}$ is well known that all human actions and activities leave their mark on the evolution of society. The traces that human actions leave also embody the features of the society where people lived over the time and their conditions and way of life as well. Social, economic but also political changes leave too notable prints, often defining, on the values and way of life, natural landscapes, monuments and archaeological sites. The evolution of society and continuous changes of the world that we are living in are mirrored by the cultural heritage, the state and protection of which are an important indicator of the development level of society and its educational and cultural level. Within this context, it is noteworthy that there are states and nations that consider themselves as part of the civilised world, characterised by variety and multiculturalism, most often embracing changes occurring owing to the political, economic, social and cultural circumstances. On the other hand, there are states and nations where changes and evolutions for the better are not entirely embraced, but rather ignored. In the states in the first category, within the society there is a notable constant concern for the cultural heritage, but also a concern and accountability within the society, regardless any political, ethnic or confessional affiliation. In fact, there are states which adhered to the UN decisions regarding recognition of the cultural heritage as an important factor of durable development, social inclusion and integration, supporting 
the protection of the universal cultural heritage and its importance for the evolution of human society. For these reasons, Romania should adopt all successful practices in the field of protection and valuation of the cultural heritage applied in the other states. Therefore, the protection of the cultural heritage of Romania should exceed the limits of cultural or educational importance and become a national priority. Furthermore, the cultural heritage must become one of the key pillars in the construction of a society, while the cultural heritage, by the opportunity of all to access the provided benefits, to contribute to the durable development of the Romanian society. In fact, it is only this way that the cultural heritage, regardless its identity or confessional belonging, would become to truly represent the legacy left by preceding generations, especially since it was created by people for the people.

The main goal of this approach ${ }^{1}$ is to present certain aspects, both positive and negative, which involve the management, protection and research of the Dacian fortresses Bănița, Costești-Blidaru, Costești-Cetățuie, Piatra Roșie, Sarmizegetusa Regia and Căpâlna on the List of UNESCO world heritage since $1999^{2}$. The six fortresses delimit an area of ca. $150 \mathrm{~km}^{2}$ which, for almost two decades, was the most extensively inhabited area from $\mathrm{Dacia}^{3}$ (Pl. 1/1).

In presenting these aspects, we are mainly supported by working visits, carried out on site over several years, as well as the knowledge of the circumstances prior the inclusion of this fortified complex on the List of UNESCO world heritage sites, but also by the information supplied by the colleagues more or less involved in activities related to the archaeological research in these sites. The connection with this monument unique in the world was systematic, owing to our concerns for the protection and enhanced use of the archaeological heritage of Romania.

Sarmizegetusa Regia (Pl. 1/2; 2-3), capital of the Dacian Kingdom, together with the fortresses of Bănița (Pl. 8/1; 9), Costești-Blidaru (Pl. 4/2; 5/2; 6; 7/2), CosteștiCetățuie (Pl. 4/1; 5/1; 7/1), Piatra Roșie (Pl. 4/3) and Căpâlna ${ }^{4}$ (Pl. 8/2) count among the best known ancient monuments of Romania. They are a unique synthesis of external cultural influences and local traditions as regards the construction techniques, in general of the ancient military architecture ${ }^{5}$, representing the monumental expression of the Dacian

This study is an ampler, more elaborate version of that titled "Câteva observații privind administrarea Cetăților dacice din Munții Orăștiei înscrise în lista patrimoniului mondial UNESCO / A few notes on the management of the Dacian fortresses from the Orăștiei Mountains on the list on UNESCO world heritage sites", which we published in the journal Plural. HistoryCulture-Society 6/2, 2018, p. 78-111.

2 https://whc.unesco.org/en/list/906

MATEESCU/PUPEZĂ 2016, 221

For the history of research of these fortifications see DAICOVICIU/ FERENCZI/GLODARIU 1989, 121-173; GHEORGHIU 2005, 17-23; MATEESCU 2017.

5 The six fortresses, alike other from within or outside this area, lay on high relief forms, in highly difficult accessible positions. Land peculiarities were enhanced so they would benefit of excellent natural defence, some being built on high cliffs, with almost vertical walls. For the military architecture see GLODARIU 1983; DAICOVICIU/FERENCZI/GLODARIU 1989, 69 sqq.; MATEESCU/PUPEZĂ 2016, 221-249. kingdom civilisation ${ }^{6}$.

All these fortresses date to the 1st century AD early 2nd century AD and form a fortified complex known under the generic name of the Dacian fortresses of the Orăştiei Mountains, although those at Bănița and Căpâlna ${ }^{7}$ lie somewhat further than the four located in the mountain area south of Orăștie. Geographically, all six fortresses are situated in the Șureanu Mountains (Sebeș), mountain group of Șureanu-Parâng-Lotrului Mountains, which belong to the mountain chain of the Southern Carpathians. The S,ureanu Mountains (Sebeș) ${ }^{8}$ are delimited to the north by the Mures, valley, east by Cindrel Mountains, to the south by the Petroșani depression, and to the west by the Hațeg depression. Westward, they extend much under the name of Luncani platform. These mountains form an ensemble of surfaces with heights comprised between 950-1000 m and less over $2000 \mathrm{~m}$, without being separated by marked dislevelment ${ }^{9}$. All these six Dacian fortresses which form a homogenous complex of fortifications lie within this mountain area (Cf. Pl. 1/1). Nevertheless, it must be argued that the phrase the Dacian fortresses of the Orăştiei Mountains may also be used for the stone walled fortresses of Bănița and Căpâlna, yet also for other few, precisely by the fact they belong to this fortification system from the Orăștiei Mountains ${ }^{10}$, built around Sarmizegetusa.

The Dacian fortresses on the UNESCO World Heritage Sites list together with other fortifications from the area are the specific expression of the exceptional development level of the Dacian civilisation from the 1st century BC - early 2nd century AD, Sarmizegetusa Regia being the forefront of this fortified complex, which represent an example for the phenomenon of the evolution from the fortified centres to proto-urban agglomerations (oppida), specific to the end of the Iron Age in Europe ${ }^{11}$. Based on the archaeological finds, the scale size, the result supplied by the LIDAR scanning and survey measures, as well as the presence of several principles of the classic urbanism, in the case of Sarmizegetusa Regia one may speak even of an urban settlement.

The recognition of the universal value of this fortified complex composed of several Dacian fortresses obviously brings prestige, but especially responsibilities, mainly for the central and local authorities of the Romanian state.

For the implementation of the Convention concerning the Protection of the World Cultural and Natural Heritage,

\footnotetext{
In Antiquity, access to these fortresses was made by a networks of roads on the crest, river valleys reaching them today being at the time inaccessible.

The Dacian fortresses of Bănița (Hunedoara county) and Căpâlna (Alba county) are somewhat peripheral to the system of the Dacian fortifications in the Orăștiei Mountains. The first lies by the western limit of the Jiu river valley, in the southern part of the Șureanu Mountains, and the second in the north-eastern area. The fortress of Bănița was designed to protect the southern side of the access to Sarmizegetusa Regia (GHEORGHIU 2005, 26), and that of Căpâlna controlled the Sebeș valley and was meant to defend the outlet from the intra-Carpathian area of the road running from south the Carpathians past the Dacian fortresses at Polovragi, and that coming from the east, from the Dacian fortress of Tilișca. The fortress of Căpâlna made easy connection also with the Dacian fortress of Cugur lying westwards (Cf. GLODARIU/MOGA 1989, 126-130.

See to this effect DAICOVICIU/FERENCZI/GLODARIU 1989, 21 sqq.; GHEORGHIU 2005, 12-13.

9 DAICOVICIU/FERENCZI/GLODARIU 1989, 21-23.

10 Cf. DAICOVICIU/FERENCZI/GLODARIU 1989, 69 sqq.;
}

11 See to this effect FLOREA 2011. 
passed by UNESCO in 1972 and to which Romania adhered in 1990, was issued the Government Ordinance $47 / 2000$ on the establishment of protection measures of the historical monuments included on the List of world heritage. It was approved with amendments by Law $564 / 2001$. Unfortunately, many regulations in this law are neither complied with nor applied by either central or local authorities. For instance, it stipulates among other, than the protection and management programme of the historical monuments listed among world heritage sites is drafted for 5-year periods by the Ministry of Culture and Cults, approved by the National Commission of the Historical Monuments and further approved by Government Resolution (Art. 6, 2) or that the Historical monuments included on the List of world heritage sites are special objectives, while their security shall be ensured, free of charge, by the Ministry of Internal Affairs (Art. $6,6)$. In the case of Art. 6, 2, a methodology was also issued, approved by Government Resolution 493/2004. It regulates both the monitoring of the historical monuments on the world heritage list (appendix 1), as well as the methodology for the draft and frame-content of the protection and management plans for the historical monuments on the List of world heritage sites (Appendix 2). This stipulates among other that the preservation state of the monuments must be monitored twice a year. Unfortunately, to date, no such plans were drafted, to our knowledge, for the management of the six Dacian fortresses that form this fortified complex included on the list of world heritage sites ${ }^{12}$. To this lack of management plans adds the lack of managers for these monuments, but also the lack of management plans according to article 6 in the Government Ordinance 47/2000 and Law $564 / 2001$ and in accordance with Government Resolution 1268 of 2010, with further amendments and completions. Last but not least, it must be said that for the fortresses of Bănița, Costești-Blidaru, Costești-Cetățuie, Piatra Roșie, Căpâlna there is not even a short-term strategy that would solve urgent matters.

The lack of the necessary documentation for the management of these fortresses, of the site managers, of the adequate specialty personnel, clear delimiting of the responsibilities and status of these sites, as well as the lack of management plans, are only a few of the multiple issues which hinder the adequate management of these monuments.

Additionally, the Programme for the protection and management of the historical monuments included on the List of World Heritage Sites approved in 2010 by Government Resolution 1268 and updated by Government Resolution 1102 of 2011 has expired. It provided for the establishment of World Heritage Committees ${ }^{13}$, the draft of the yearly plans for each monument, under the Frame-Programme and the appointment of coordinators for these monuments, whose

12 Of the six Romanian cultural sites among the World Heritage Sites, a management plan has only the Horezu Abbey (2013-2019). See to this effect https://patrimoniu.ro/images/rapoarte-unesco-2015/Plan-de-managementManastirea-Horezu1-08-2013.pdf

13 The World Heritage Committee is composed of as follows: a representative of the Ministry of Culture, a representative of the County Directorate of Culture, a representative of the County Council, a representative of the specialised structure with the Romanian Police, a representative of the local community and the coordinator of the monument, appointed by the County Council (under article 10, 1 of Government Resolution 1268/2010). duty was also to implement the plans. In 2012, the County Council of Alba set up the World Heritage Committees for the Dacian fortress at Căpâlna, under the coordination of dr. Constantin Inel. For this fortress, a project for the research, restoration and valuation was submitted, approved by the Ministry of Culture, however which failed implementation because of the uncertain legal status. Interestingly, this project was not discussed, as it would have been normal, at the level of the World Heritage Committees for the Dacian fortresses. In 2014, the County Council of Hunedoara set up said Committees for the Dacian fortresses of Bănița, CosteștiBlidaru, Costești-Cetățuie, Piatra Roșie and Sarmizegetusa Regia, all under the coordination of dr. Cătălin Cristescu ${ }^{14}$.

Concerning these Committees, we wish to mention they have a series of attributions ${ }^{15}$, however they are not provided with specific leverage to direct and carry out with maximum efficiency their activities and accomplish the goal for which they were created. The two coordinators of the monuments had not and still do not have enough legal prerogatives to act and conduct in a real manner their management activity. Even more, a series of priorities and requirements submitted for resolution to central and local authorities by the Committees, which would have contributed to the proper course of things, including the fulfilment of the attributions of the Committee, have been ignored, while their resolution did not take any shape.

Unfortunately, starting with August of 2016, dr. Cătălin Cristescu is no longer the coordinator of this Committee, with another person appointed in his place. There also counts the fact that for a while, the meetings of the Committee for the monuments at Bănița, Costești-Blidaru, Costești-Cetățuie, Piatra Roșie and Sarmizegetusa Regia were not held. No such meetings were assembled for the Dacian fortress at Căpâlna, which remained without coordinator ${ }^{16}$. Under such circumstances, when these Committees did not function at least in the last two years, we wonder how were the provisions of Government Resolution 1268/2010 complied with, as under Article 11, b it is stipulated that the members of the Committee perform inspections for the periodical monitoring of the maintenance works carried out at the monuments at least twice a year.

For the lack of a management plan for each fortress, the absent site managers, who practically complete and draft section II of the report and that of the Committee coordinator, the question rises as to whom, what and based on what the following report to the UNESCO World Heritage Centre will be made. Most likely, like in the past, such

\footnotetext{
${ }_{14}$ We thank this way our colleague and friend dr. Cătălin Cristescu for being so kind to provide us with information regarding the key issues of the Dacian fortresses in the Orăștie Mountains.

15 In accordance with Government Resolution 1268/2010 (article 10, 2), the attributions of the World Heritage Committee are the following: 1. To draft a strategy for the maintenance of the monuments and prevention of any possible factors threatening their integrity; 2 . To draft the protection, preservation and maintenance plans, as well as the rehabilitation, promotion and valuation of the monument; 3 . To draft periodical notices regarding the preservation state of the monuments, the general or specific issues noted subsequent to the monitoring inspections; 4 . To hold public debates to draw attention on the importance on the well preservation of the monument and the measures considered for the improvement of its preservation state, promotion and valuation.

16 Starting with the 1st of August 2018, Constantin Inel is the manager of the
} Arad Museum Complex. 
periodical report will include much inaccurate, incomplete or unrelated data to the real state of these monuments, which deprive the Dacian fortresses from the possibility to benefit from UNESCO, respectively international or national bodies' aid.

Another thorny issue still unresolved by the Romanian authorities regards the constant security of the monuments, required on several occasions by the scientific responsible of the Dacian fortresses in the Orăștie Mountains, but also by the coordinator of the World Heritage Committees of these monuments from the territory of Hunedoara county. Such requests were sent including to Romania's President, the Prime-Minister, Minister of Culture, Standing Commission of the Romanian Parliament for the relation with UNESCO, but also the Institution of the Prefect of Hunedoara County.

Although the Romanian authorities have recognised the universal value of this fortified complex that brings prestige to Romania, they have been ignoring for years that they are accountable and have their obligations. The Romanian State listed most of them in Government Ordinance 47/2000 and Law 564/2001, emphasizing, in article 3,3 , the fact that the valuation of the listed monuments is an objective of national interest and that, according to the law, for their protection, expropriation for cause of public utility may be enforceable. Also, article 4 of GO 47/2000 specifies that the funding of the security of the historical monuments part of the world heritage shall be borne by the owners, administrators or holders of other real rights, if applicable. Article 6, 6 mentions that the security of the historical monuments part of the world heritage shall be carried out by effectives or sub-units of the Ministry of Internal Affairs, under conditions set by a Government Resolution. Article 9 stipulates that authorities of the local public administration have among the main attributions also the establishment of security and protection measures of the historical monuments part of the world heritage, regardless their property regime, reporting to the decentralized public services of the Ministry of Culture, immediately, any noncompliance with the law (i). In Law 564/2001, article 6,6 mentions that these monuments are special objectives, while their security shall be ensured, free of charge, by the Ministry of Internal Affairs. Therefore, the text of the laws shows that central and local authorities must ensure the security of these archaeological monuments. After 9-10 years from the issue of mentioned regulations, the Romanian Government has issued Government Resolution 1268/2010 regarding the approval of the Protection and Management Programme of the Historical Monuments included on the List of UNESCO World Heritage. Article 11, a, stipulates provision of constant security of the monuments by the Ministry of Administration and Internal Affairs, with the support of county and local authorities in whose range the monument lies. Nevertheless, it must be mentioned that currently, the single Dacian fortress in the Orăștie Mountains that benefits of security/ surveillance services $24 / 24$ is Sarmizegetusa Regia. It is though, by the end of 2012, under the administration of the County Council of Hunedoara ${ }^{17}$, which by Resolution

\footnotetext{
The transfer of Sarmizegetusa Regia under the administration of the County Council of Hunedoara was made under Government Resolution 1237/2012, published in the Official Gazette 876 of 21 December 2012.
}

40/2013 established the Administration of the Historical Monument of Sarmizegetusa Regia, which explains the positive advances in the management of this fortress. In order to ensure the constant surveillance/security of the area and stop archaeological poaching and vandalism actions, the County Council of Hunedoara employed for permanent security services for Sarmizegetusa Regia a specialised company ${ }^{18}$. Subsequent to these measures, the phenomenon of the archaeological poaching and deliberate destruction disappeared entirely in the administered area. Not the same applies for the remaining fortresses, where destruction and archaeological poaching are not rare. In the case of the fortress at Căpâlna, we wish to mention it is guarded by a person employed for such purpose by the National Museum of the Union of Alba Iulia.

In September 2015, it was reported that within the perimeter of the Dacian fortress at Costești-Cetățuie, monument currently not administered, tens of pits were illegally excavated and that some monuments suffered damages, namely two tower-houses on the higher plateau of the fortification, remarkable architectural elements and symbol of this UNESCO monument. Including some of the drums from the temples outside the fortress's enclosure were vandalised. Recently, near the temple which lies outside the rampart from the Costești-Cetăție fortress, such a group of spiritual preoccupations excavated 12 pits set in the circle, in which were set stones, fire traces being also identified ${ }^{19}$.

Furthermore, it was noted that in the other Dacian fortresses in the range of Hunedoara county (Bănița, Costești-Blidaru and Piatra Roșie) from the list of world heritage sites were vandalised. Similarly to the fortress at Costești-Cetățuie, the latter are also not administered.

These fortresses, part of the universal cultural heritage, are the only UNESCO monuments from the entire world without legal owner, and the central state authorities are mainly to blame for such state of facts (Government, Parliament), which can quickly resolve their transfer to the administration of the authorities in the counties of Hunedoara and Alba, the only ones able to protect, at least for the time being, these UNESCO monuments. Even the representatives of the Ministry of Culture and the National Institute of Heritage in the UNESCO Committees have noted the remarkable positive effects of the transfer to the administration of the County Council of Hunedoara of the area of 18.3 ha area onto which lie the main vestiges of the site at Sarmizegetusa Regia.

Nevertheless, it must be underlined that, although the County Council of Hunedoara, subsequent to the positive

\footnotetext{
18 The employment of a private company was necessary because the Ministry of Internal Affairs does not wish to ensure the $24 / 24$ security of the site, as provisioned by article 6, 6 of Law 564/2001 and article 11, a, of Government Resolution 1268/2010 because the historical monuments on the UNESCO world heritage list are not also on the list of the objectives excepted from payment listed by Government Resolution 1486/2005 that regulates the insurance of security and protection of the objectives, assets and valuables with gendarmes. Furthermore, it is invoked that these monuments do not comply with a series of conditions for permanent security. To this effect, even an assessment has been drawn up, resulting in certain requests and claims, yet it seems they cannot be put into practice in a UNESCO site.

19 http://www.replicahd.ro/un-nou-templu-in-cetatea-dacica-costesti/?fb clid=IwAR2bTWHtZEThJnLK8C3KxpnLthiWVrNrwknA8DKCYJ8NT vVy248Zjg8R8Q
} 
results recorded in the administration of the historical monument Sarmizegetusa Regia, requested repeatedly to the authorised central authorities the transfer of the administration right of the other Dacian fortresses from the county of Hunedoara ${ }^{20}$, this was constantly refused, based on derisory reasons or the requests of additional documentations or futile procedures. Requests for specific actions for the transfer of the administration right of the Dacian fortresses on the UNESCO world heritage list to the County Council of Hunedoara were submitted until 2016 also by dr. Cătălin Cristescu, coordinator of the UNESCO Committee of the monuments at Bănița, CosteștiBlidaru, Costești-Cetățuie, Piatra Roșie and Sarmizegetusa Regia $^{21}$. Despite the success of taking the administration of Sarmizegetusa Regia by the County Council of Hunedoara, the Ministry of Culture and National Identity wished not to carry until present necessary steps to make possible the delivery for administration also of the other fortresses in this fortified complex ${ }^{22}$.

The lack of an administrator and lacking presence of Romanian state authorities in the area of the Dacian fortresses contributed to persistent vandalism acts and archaeological poaching by the use of metal detectors in almost all the other fortresses of this fortified complex, including in the perimeter of the settlement at Fețele Albe, nearby the capital of the Dacian kingdom ${ }^{23}$. In the autumn of 2018 within the perimeter of this settlement started a powerful fire, which damages most part of the walls and structures made of limestone blocks. The cause was the candles lit by a group with spiritual concerns practicing rituals of connection to the enrgies of these ancient sacred places ${ }^{24}$. For the

20 For more recent requests see also http://hunedoaralibera.ro/oficial-cjhunedoara-solicita-cetatile-dacice-din-muntii-orastiei/

https://gddhd.ro/actualitate/cetatile-dacice-cerute-din-nou-in-administrare/ 21 Information dr. Cătălin Cristescu.

22 A first step to this effect must be taken by the Ministry of Culture and National Identity, which is bound to carry out the necessary steps so that these monuments be registered in the centralised inventory of state public property assets, as was the case of Sarmizegetusa Regia, and which is the mandatory condition that these fortresses be fitted with an administrator. This was not carried out even today although Law 213 of 17 November 1998 for the public property and legal regime clearly results from Appendix 1. I, no. 27, that the historical and archaeological ensembles and sites are part of the state public property. The following step is to designate by a Government resolution the Ministry of Culture and National Identity as administrator, which can transfer the administration right to county authorities.

${ }_{23}$ See also https://adevarul.ro/locale/hunedoara/video-traficantii-comoris-au-intors-cetatile-dacilor-ultimul-atac-lungul-sir-actelor-braconajarheologic-1 55fbe660f5eaafab2cbc9af8/index.html

http://stiri.tvr.ro/cetatea-dacica-costesti-din-muntii-orastiei-afost-vandalizata_65334.html\#view

https://gddhd.ro/breaking-news/vandalismul-din-cetatile-dacicee-de-fapt-braconaj-arheologic-patru-cetateni-cehi-cercetati-pentru-furt-debunuri-de-patrimoniu-din-cetatile-din-muntii-orastiei/

http://proalba.ro/doi-braconieri-de-comori-prinsi-in-flagrantla-cetatea-dacica-din-capalna-au-folosit-detectoare-de-metale-in-siturilearheologice

https://adevarul.ro/locale/hunedoara/cetate-dacica-vandalizatasfantul-gyurcan-profanatorul-ofera-1000-euro-recompensa-gasirea-lui1_56997fcc37115986c689139c/index.html

https://glasul-hd.ro/cetatile-dacice-de-la-costesti-si-blidaru-aufost-vandalizate/

24 http://www.replicahd.ro/arde-in-situl-fetele-albe-lumanarilepuse-de-credinciosi-daci-risca-sa-faca-scrum/?fbclid=IwAR0SjgWP6KKIFB heLTsZXQnidp6YiszVVyAVXl6upwDJUbRpPXdZ2tGnWtI

https://adevarul.ro/locale/hunedoara/cetatile-dacicejurul-sarmizegetusei-regia-fost-lasate-prada-profanatorilor- latter, the County Council of Hunedoara has also requested the right of administration, which remained also without any result. This state of facts indicates that at the level of the central authorities there is insufficient will to apply the law in force or the draft and amendment of laws that would allow the security and protection $24 / 7$.

Visits in the recent years in the Dacian fortresses with no legal ownership, reveal they are practically available at any time to anybody. Even if in the last years, surface destructions of these sites unique in the world resulted from treasure hunting or the lack of education or civic sense of the visitors have diminished, the danger for their integrity remains, while the damage incurred in some cases cannot be repaired or corrected. Recent events when the fortress at Costești-Cetățuie was vandalised, with 4 blocks of the second tower-house dislodged, and one of the foundation blocks of the tower on the upper plateau moved and chipped, further confirm that the lack of an administrator has and will have negative consequences not only for short-term but especially for medium and long-terms. Even if archaeological excavations continue yearly, mainly at Sarmizegetusa Regia, for the lack of substantial financial support on the part of the Ministry of Culture and National Identity and local authorities, these monument risk significant damages, while part of them will physically disappear over time, unless constant financial sources for their preservation, conservation and protection are allotted. The location of the Dacian fortresses in mountainous areas exposes them to bad weather (excess humidity, low temperatures, abundant rainfalls, landslides, storms, all with multiple negative effects) that contributes to their quick deterioration, which further emphasizes that preservation and restoration measures must be supported and constantly taken by the authorities.

Other major issues that remained unresolved, although their settlement was requested on countless occasions by the World Heritage Committees for the monuments at Bănița, Costești-Blidaru, Costești-Cetățuie, Piatra Roșie and Sarmizegetusa Regia, key for the legality of their administration, are related to a series of aspects ${ }^{25}$ :

- settlement of the legal regime of all lands on which mentioned monuments lie, including of those in the related protection areas, and their registration.

- performance of cadastre works for the lands.

- establishment of the owners of the administration rights of the UNESCO remains.

- inclusion of the monuments and protection areas in Regional Town Planning and General Urban Plan documentations of the administrative-territorial units within the range of which respective monuments lie.

Also, documentations for the draft of large scale feasibility studies for each fortress were not drawn up. The single exception is Sarmizegetusa Regia, for which the documentation for the intervention works was recently completed and approved (D.A.L.I.), drafted by the National Institute of Heritage and funded by the County Council of Hunedoara.

It must be noted in the case of the few stated aspects

$\frac{1 \text { 1_541fc40a0d133766a8545b6c/index.html }}{25 \text { Information dr. Cătălin Cristescu. }}$ 
that their resolution falls under the responsibility of local and central authorities, as stipulated in article 7 in Government Ordinance 47/2000 and Law 564/2001 for the approval of Government Ordinance 47/2000 on the establishment of protection measures of the historical world heritage listed monuments.

The lack of a legal administrator of the fortresses at Bănița, Costești-Blidaru, Costești-Cetățuie, Piatra Roșie and Căpâlna is obvious in many aspects. For instance, access paths to some of these Dacian fortresses are not corresponding, in some cases they being even difficult (Pl. 10/2-3, 12/2, 16/3-4, 18/4). Access to the fortress at Bănița is very difficult and possible only from the railway SimeriaPetroșani, which cuts the civil settlement by the feet of the fortress. Even so, there is not even a track set up for the access of the tourists, ascending being dangerous and almost impracticable for those unfamiliar with the place. In a deplorable state is also county road 668A which leads to the fortress Piatra Roșie from Boșorod, while the part which should make the connection with the valley where the fortresses at Costești-Blidaru, Costești-Cetățuie and Sarmizegetusa Regia lie, cannot be crossed unless forestry tractors or off-road vehicles are used. Access to the fortress Costești-Blidaru is possible only on foot, for $2 \mathrm{~km}$ on a rather difficult road, undeveloped and unmaintained, while in that at Costești-Cetăție by $3 \mathrm{~km}$ on an acceptable road.

All these lack the yearly action plan for the management of the monument, as provided by the law. Facilities for visitors are lacking almost entirely in all fortresses, while information panels by the entrance into the sites, made decades ago, are in some cases almost illegible (Cf. Pl. 10/6; 12/3-4; 16/2; 18/3). There are no explanatory panels for each objective from their perimeter either. In the places where some of these fortresses are, there are no information centres or kiosks. Once these fortresses are reached, tourists note there are no adequate information materials and no place where they could acquire a flyer or a brochure with all primary information regarding the monument.

In almost all these fortresses, there is a noticeable decay of the monuments, but also notable year by year careless appearance. In almost all these fortresses, there are constructions in ruin and dislodged walls in several places. The vegetation there conquered the monuments, while significant surfaces of the walls and constructions are covered with layers of moss, lichens and briophytes. At Bănița, the monuments may be barely seen on the surface (Pl. 20/2-6), while at Piatra Roșie (Pl. 16/5-6; 17/1-6) and Căpâlna (Pl. 18/5-6; 19) the situation is not much better, in all three the preservation state is rather poor. The difficult access to the fortress at Bănița, accessible only for climbers and almost impossible for the rest willing to visit the fortress, even for specialists, has shielded it from being vandalised or from archaeological poaching. On the other hand, those concerned and fond of history are deprived from visiting this fortress, which in its glory days, surveilled and controlled access from the Jiu river valley. Once you reach the place, you note that the monument is neglected and abandoned, even if it is included on list of world heritage monuments, being an asset of humankind.

Of the 5 fortresses without legal administrator, the best situation is found at Costesti-Blidaru, where there is a caretaker, who, to his capabilities, also maintains the appearance of the fortress (Cf. Pl. 11). Nonetheless, wall dislodgments are visible there too, even cistern damages. Because the fortress at Costești-Blidaru is barely accessible, deliberate destruction in this site is rare. At Costești-Cetățuie, until not long ago, the most visited and maintained fortress, there is a notable decay in appearance and care (Pl. 12/4-6; $14 ; 15)$. In tower-houses I and II, the advanced decay of the metal sheet roofs is clearly visible (Pl. 13/1-6). They display fissures and holes which allow water and snow to enter, the walls' filling and brick elevation being thus damaged in several places. The protections system of these towers, made in the 80 'ies of the 20th century, is in poor state, almost fallen in some areas and unaesthetic. In several places of these brick walls, intended destruction is visible. Furthermore, purposeful destruction of the fortress walls has increased, but also the presence of several personalised inscriptions on the blocks of the fortress walls. More than that, the fortress is systematically destroyed by the cattle left to feed around its walls by the local inhabitants. The state that the fortress at Costești-Cetătuie reached in the most recent years is also due to the fact that the person caring for its maintenance retired, while the Museum of Deva, his employer, no longer has any legal leverage to hire another individual other than the owner's appointee. Most likely, in a few years, the fortresses at Costești-Blidaru and Piatra Roșie, each with one caretaker, both on the payment roll of the Museum of Dacian and Roman Civilisation of Deva will find themselves in the same situation.

Last but not least, we wish to mention the actions of the County Council of Hunedoara in partnership with the Scientific Council responsible for the Dacian fortresses in the Orăștie Mountains, the National Park Grădiștea MunceluluiCioclovina, the Museum of Dacian and Roman Civilisation, the Forestry Directorate of Hunedoara and Prefecture to clean last year the Dacian fortresses of Costești-Cetățuie, Costești-Blidaru, Piatra Roșie and the settlement at Fețele Albe. This action, beside other efforts, represents steps to prove that county authorities are more responsible than those central and that they can optimally care for all Dacian fortresses and not only for Sarmizegetusa Regia.

At Sarmizegetusa Regia, from December 2012 under the administration of the County Council of Hunedoara, which established the Administration of the Historical Monument Sarmizegetusa Regia ${ }^{26}$, things changed for the better in the last six years ${ }^{27}$, while desolate images, like those until 2012 (Pl. 24), are no longer seen. Nevertheless, it must be said there is still much to do, and also there is still place for changes and consistent improvements in the management, preservation and protection of this site. Currently, the site benefits of 24/24 surveillance services carried out by a specialised firm, silence and public order ensured by the Romanian Gendarmerie, video surveillance and a well tuned security plan. All these led to the complete disappearance of archaeological poaching and vandalism in the administered area. Nevertheless, solutions for the extension of the

\footnotetext{
26 The present structure is called the Public Service of Administration of the Historical Monuments.

27 VASILESCU 2018, BÂRCĂ 2018a. See and BÂRCĂ 2018.
} 
monitoring/security of the entire monuments should be found, even though it is difficult for large surfaces ${ }^{28}$. It is certain though that the management of the surface of 18.3 ha, on which lay the main remains, is insufficient for the protection of the site throughout ${ }^{29}$.

Yearly, the managed perimeter is and certain places in the protection area are cleaned by trees (Pl. 25/1, 3). These actions, beside those of cleaning the stone structures changed for the better the face of the monument. Toilets were set up by the entrance into the site, even though the place is not quite suitable.

Additionally, a Consulting Scientific Council was set up, formed especially of specialists from all institutions with attributions in the protection of the heritage and research of the monument. It supervises decisions taken for the monument in terms of fairness and limits of the law.

A programme and regulation for visiting the site was drafted and implemented (Pl. 21/1-2), to contribute to the efficient protection of the monument and insurance of a civilised touristic system. Visiting routes were set up for the monument enclosure and explanatory panels with texts in Romanian and English for each monument were placed (Pl. 2/2; 22/1-4, 23/1). Within the entire perimeter of the site were placed garbage bins, but also wooden benches. In the administration pavilion by the entrance into the site may be purchased adequate informative materials (flyers, brochures, books) with primary information on the monument, but also with various souvenirs (Pl. 21/6). Also, there were introduced audio guides in Romanian and English with much information and its history. This could be supplemented, during the periods when the number of tourists is very high, and the presence of certain specialists for professional guiding.

The administration and Gendarmerie were equipped with two wooden pavilions, mobile and provisional ( $\mathrm{Pl}$. 21/6), adapted to realities and without impacting the archaeological strata, while the building by the entrance on Albă Valley was refurbished. In the latter operated the surveillance base of the valley, the exhibition hall and the gendarmerie headquarters. The county road $705 \mathrm{~A}$ which runs to Sarmizegetusa Regia was modernised ${ }^{30}$ (Pl. 25/5-6), while at ca. $1 \mathrm{~km}$ from the entrance to the fortress a parking

\footnotetext{
28 It should be mentioned that in these unmonitored areas of the monuments were discovered and illegally removed by archaeological poaching, most hoards and deposits with pieces of inestimable value.

29 Until measures for the entire site's surveillance are taken, the survey measures and accurate plan of the site and its extension must not be published. Otherwise, such accurate data would be made available for those who practice archaeological poaching.

30 The $18 \mathrm{~km}$ road that runs to the Dacian fortress of Sarmizegetusa Regia was modernised in 2015-2016 subsequent to European funds accessed by county authorities. The total value of the works amounted to lei 41,587,526.93 lei, of which Lei 33,616,347.55 eligible costs to which add lei 7,971,179.38 lei VAT. Of this amount, the contribution of the European Union was of Lei 29,078,140.63 lei $-86.50 \%$; the state budget contribution was of $3,865,879.96$ lei $-11.50 \%$, while the remaining $2.00 \%$ was private contribution. Unfortunately, this road broke three times in the last two years, in 2018 sliding twice on several parts, on July the 26 and 1st of August. Rainfalls and landslides that contribute to the deterioration of a road portion add to the poor quality works. For more details see https://presshub.ro/banieuropeni/2018/10/11/ drumul-spre-sarmizegetusa-regia-modernizat-in-2016-cu-fondurieuropene-s-a-rupt-de-trei-ori-in-doi-ani-cazul-este-cercetat-de-procurorii$\underline{\mathrm{dna} / \text { ?fbclid=IwAR1UTVCQhqUG6htxrLmAc_sKqfZnxcLbYpwIOsPMt- }}$
} cv0wHvMIdpq5jdRGY (11.10.2018). lot was set up (Pl. 21/4). On this $1 \mathrm{~km}$ part access is only by foot ((Pl. 21/5). The efforts of the County Council of Hunedoara and the Site Administration resulted in the site's orderly appearance (Pl. 22/5; 23/2-4, 6), constantly cleaned, regardless the season, thus fulfilling one of the standards that UNESCO monuments must comply with. The strict enforcement of the regulation resulted in maintaining the order, removal of inadequate behaviour and vandalism, as well as the protection of the architectural elements from the managed area. Yearly, the tourists are more civilised regarding the monument and its natural environment.

Recently, the assessment procedure of the site of Sarmizegetusa Regia has been initiated in order to records its value in accounting books and for the completion of the Government resolution no. 1705 of 29 November 2006 as regards the approval of the centralised inventory of the state public assets. This measure was required by the Romanian Court of Accounts subsequent to a check finalised by the end of 2016, which order the assessment and record in the books by the Public Service for the Management of the Historical Sites with the County Council of Hunedoara, of the fixed assets and other unassessed property, like buildings and land, which composed the historical site of Sarmizegetusa Regia. Beyond these aspects of the law which stipulates the assessment of the value of the assets in the state public property, two questions arise: $\mathbf{1}$. Which was the money value of the site upon its delivery for administration by the County Council of Hunedoara? 2. How will the accounting value of this site be established?

For the information of those interested to visit Sarmizegetusa Regia, a website was made ${ }^{31}$. It supplies a series of important information about the history of research, points, location, regulation, visiting routes, events, programme and visiting regulations, and many other aspects. The events and actions ocurring at Sarmizegetusa Regia, but also a series of technical aspects are promoted also on the official page of the management on Facebook ${ }^{32}$. Therefore, the Programul Multianual de Cercetări Arheologice din Munţii Orăştiei (Multiannual Programme of Archaeological Research from the Orăştiei Mountains) coordinated by the National Museum of Transylvanian History from Cluj-Napoca, developed over 2012-2015 ${ }^{33}$, created a complex website dedicated to the Dacian fortresses of Orăștiei Mountains on the World Heritage Sites list ${ }^{34}$.

For a few years, the County Council of Hunedoara financially supports also the archaeological research, which led to the significant extension of the excavation period, thus contributing to remarkable results and impressive finds ${ }^{35}$. In the support of the County Council of Hunedoara

\footnotetext{
https://cetateasarmizegetusa.ro/

2 https://www.facebook.com/sarmizegetusaregiapaginaoficiala/

The programme spans over a four year period, in which systematic and multi-disciplinary archaeological excavations were carried out in the Dacian fortresses of Orăştiei Mountains. The goal of this funding project was to increase scientific information on the Dacian sites and inhabitancy from the Orăştiei Mountains. For this, a series of equipments were purchased and investments were made in multi-disciplinary tests and research which highly contributed in the quality increase of the scientific act.

34 http://www.cetati-dacice.ro/ro

We thank this was the research team of Sarmizegetusa Regia, led by Professor Gelu Florea, for their openness and kindness to present on site the finds of the last two years.
} 
came the Babeș-Bolyai University leased for a long term the school building from Grădiștea de Munte and turned it into a state of the art archaeological base. Also, the Museum of Dacian and Roman Civilisation of Deva and the National Museum of Transylvanian History have also provided logistical aid, to which also adds the effort of the team from the Technical University of Cluj-Napoca headed by Professor dr. Călin Neamțu, who have been scanning by 3D technology the archaeological excavations and unveiled remains for four years (Pl. 27). Also, here should be added the survey performed by modern methods and the draft of an accurate plan of the site and its extension ${ }^{36}$ by a team of the Faculty of Geography with the Babeș-Bolyai University. The measures have shown that on the main axis, along the central hill crest, the site spreads over a length of $4.5 \mathrm{~km}$ and includes 260 manmade terraces, set up in Antiquity, but also that it stretches over a surface of almost 400 hectares of flat land. ${ }^{37}$. The site was also scanned by LIDAR, in $2012^{38}$, by a team of specialists employed by BBC working in collaboration with Discovery Channel, for the documentary film "Rome's Lost Empire". The LIDAR scanning results are currently processed and forthcoming. ${ }^{39}$. Data supplied by this active remote sensing technique will contribute to a better understanding of the realities from Sarmizegetusa Regia.

In 2017, the wooden posts from the large circular sanctuary were changed ( $\mathrm{Pl} .23 / 2$ ) and the poor state protection fence of the paved road replaced (Pl. 22/5). All these measures and efforts inevitably led to increased interest for this monument and higher numbers of tourists from 30 thousands in 2013 to 75 thousands in 2017. A positive and beneficial event for the tourists is related to the Open Gates Day held on the archaeological site of Sarmizegetusa Regia. During this day, those interested may visit the excavation and receive explanations related to the ongoing archaeological research, yet may also benefit on an ample guiding regarding the monuments from the fortress made by the specialists.

Last but not least, one should mention here also the implementation of project "Când viața cotidiană antică devine patrimoniu UNESCO. Scanarea, restaurarea digital și contextualizarea artefactelor dacice din Munții Orăștiei"40("When the ancient daily life becomes UNESCO

\footnotetext{
36 Cf. FLOREA 2017.

37 See FLOREA 2017, 363, Pl. 113/1-2. We thank this way our friend dr. Răzvan Mateescu, member of the research team of Sarmizegetusa Regia, for his kindness in supplying this information and so many other related to the archaeological research and protection of this site.

38 Cf. FLOREA 2017, 364-365. Light Detection and Ranging (LIDAR) is an active remote sensing technique by which are obtained data of high accuracy about land topography or various structures and buildings. The technology uses three basic systems - laser scanning which measures distances with precision, plus the global positioning system (GPS) and Inertial Measurement Unit (IMU) to record orientation. By the laser scanning, are recorded time differences between laser impulses sent from the plain in flight and those reflected by the topographic surface.

39 A laser LIDAR scanning will be accomplished for Sarmizegetusa Regia and the Costești-Cetățuie fortrees also by the National Institute of the Heritage https://adevarul.ro/locale/hunedoara/sarmizegetusa-regiarosia-montana-costesti-vor-scanate-tehnologie-ultima-generatiedetaliile-proiectului-cele-mai-misterioase-locuri-antice-1_5a074c075ab6550cb80f3e21/index.html; https://www.libertatea.ro/stiri/cetatea-dacica-sarmizegetusaregia-va-fi-scanata-din-avion-1896379

${ }^{40}$ We thank this way Professor Călin Neamțu with the Technical University
}

heritage. The scanning, digital restoration and contextualizing of the Dacian artefacts from the Orăștie Mountains"), a project drafted and implemented by the Technical University of Cluj-Napoca in partnership with the National Museum of Transylvanian History, the Babeş-Bolyai University and the Museum of Dacian and Roman Civilisation of Deva. The project was completed by the end of the last year and was funded through the Financial Mechanism SEE2009-2014m project line: PA16/RO12 Preserving and revitalising the cultural and natural heritage ${ }^{41}$.

Within the project, it was attempted an incursion in the Dacian daily life as resulted from the archaeological finds yielded by the almost 100 years of systematic research in the Dacian fortresses of Orăștie Mountains. Thus, over 200 representative artefacts of Dacian heritage were digitized for international promotion, as well as the conversion of over 500 digitized artefacts discovered in the Dacian sites included on the list of UNESCO heritage (Pl. 26). A database in the form of a web platform was set up, open to manage the 3D models and metadata in accordance with the Europeana portal $^{42}$, which may be later completed by additional 3D scanned models. Some of the houses and appurtenances, workshops, temples and Dacian fortifications in the Orăştie Mountains were digitally reconstructed, and a virtual tour of the museum available online was established. Also, a detailed catalogue of the real and virtual pieces was published, beside restorations of the pieces, constructions and Dacian fortresses, visible in normal layout or anaglyph ${ }^{43}$. In 2015, during the Open Gates Day, the visitors had the opportunity to interact with last generation 3D technologies used to valuate many of the Dacian vestiges from the Orăștie Mountains within this project ${ }^{44}$.

Still within the project, were set up two multimedia exhibition spaces, one in the National Museum of Transylvanian History and another in the Museum of Dacian and Roman Civilisation of Deva, which house the two mixed exhibitions: real/virtual, Incursiuni dacice în mediul virtual (Dacian incursions in virtual setting). They provide the visitors with the opportunity to interact with the virtual environment represented by the digitised artefacts and virtually reconstructed monuments. Each of the two spaces were fitted with the following equipments: multimedia 3D professional projector (1 piece), multimedia 3D projector (2 pieces), haptic device (2 pieces), an interactive table (1 piece), Microsoft kinect (3 pieces), display 3D Smart TV (3 pieces), monitor 3D 24"(6 pieces), 3D glasses, system of blinds for exhibition spaces, exhibition showcases, audio systems, lightning system for exhibition, theft-proof system ${ }^{45}$.

of Cluj-Napoca, the project manager, for being kind to supply a series of information related to the draft and implementation of this project.

${ }^{41}$ Project funded by a grant offered by Island, Liechtenstein and Norway.

42 Europeana.eu is an internet portal operating with an interface to millions of books, paintings, films, museum objects and archive records etc. digitised in Europe.

43 Cf. https://dacit.utcluj.ro/results

${ }_{44}$ We thank this way too our friend dr. Răzvan Mateescu, member of the research team of Sarmizegetusa Regia, for kindly supplying us with this information, yet also much other related to the archaeological research and protection of this monument.

45 For more information on this project and the remarkable results obtained see https://dacit.utcluj.ro/; https://www.facebook.com/dacit.utcluj; http://www.fonduri-patrimoniu.ro/proiecte_doc_101_cand-viatacotidiana-antica-devine-patrimoniu-unesco-scanarea-restaurarea-digitala-si- 
The implementation of this project has contributed in facilitating access to the Dacian heritage from the Orăștie Mountains, the interested public in these monuments easily accessing much information on the Dacian sites and understanding the importance of these remains in the Orăștie Mountains.

Past all these positive things, there are a series of aspects that still require remedy. Amongst, count the dislodgment of the blocks and constructional elements on some portions of the fortification walls (Pl. 22/1) or the pentagonal tower (part of the support wall of terrace XI) (Pl. $23 / 5$ ), as well as the poor state of the ruins of the Roman bath which are not visible enough, being covered by earth, vegetation and parts of fallen trees. In a precarious situation is also what remains of the access stairs made of limestone slabs from the southern side of the large limestone temple on terrace XI.

As known, the Dacian fortresses from the county of Hunedoara included on List of world heritage lie on the territory of the Natural Park Grădiștea MunceluluiCioclovina. It is a protected natural area, whose aim is to protect and preserve important natural habitats and species from the forestry, flora and fauna etc. views. The regulation of this park forbids activities of exploitation and use of natural resources, especially in the areas of integral protection. Within the range of the latter, also lie some of the Dacian fortresses, which often hinders both activities of archaeological research, restoration and preservation as well as those related to the administration of these monuments. Many of the trees on the surface of the Dacian fortresses are old, thus endangering both monuments and visitors. The most alarming situation is at Sarmizegetusa Regia, where old trees fall down increasingly often owing to powerful winds or storms (Pl. 28), yet also at Piatra Roșie.

In order to protect the visitors, the Administration of the site of Sarmizegetusa Regia was forced to place by the entrance into the site a panel warning the tourists of the dangers they might encounter on the visiting terraces in the Dacian fortress: "Warning, Yellow Code. Please move carefully in the forested area. Branches or trees might fall and affect your integrity. In case of storm, strong winds or rainfall signalled by the entry in the administered area, please strictly comply with the indications of the surveillance agents" (Pl. 21/3).

Because of the unclear legal situation regarding the legislation protecting the UNESCO monuments, which protects the forestry fund and that of the Natural Park Grădiştea Muncelului - Cioclovina, it was reached the situation where research cannot be carried in some areas of the site or it is possible only with the approval of Romsilva. Because of this legislation it is impossible to intervene either in case of fallen trees over the monuments, while any intervention carries criminal complaints. An example to this effect is that of the spring of 2016, when following a storm two trees had fallen over the fortress wall, destroying part of the historical monument. The employees of the Administration Service of the monument removed them, yet this led to a criminal investigation for infringement of the Forestry Code. Destruction to the monument by fallen trees contextualizarea-artefactelor-dacice-din-muntii-orastiei pg $0 . \mathrm{htm}$ is increasingly frequent in most recent years, yet legislative measures to remedy these anomalies are still pending, although many requests have been made to this effect.

Therefore, this is a case when remains unique in the world are left for destruction owing to trees that fall over them because the monuments are in a special area of protection, that of the Natural Park Grădiştea Muncelului Cioclovina. Even though for years, requests were submitted to remove the remains from Sarmizegetusa Regia from the forestry fund, not even today the issue was resolved. Not even the legislative initiative of the Parliament members from Hunedoara county to remove the fortresses from the forestry fund was successful.

Therefore, decision making authorities leave us to further see cases like that in the fall of 2017, when a wall segment, lying at ca. $25 \mathrm{~m}$ north from the eastern gate of the fortress at Sarmizegetusa Regia, had its both sides damaged by a large branch from a nearby secular tree that fell onto it. The fallen branch dislodged from brickworks ca. 20 blocks on a length of 6-7 m, the wall structure being significantly destabilised. Other five smaller blocks were crushed.

After many discussions and negotiation, it was decided to remove 103 seek trees from the site's surface, which endangered both visitors and employees, as well as important parts of the site. It was carried out by the end of the January and early February 2018 under the monitoring of the employees of the management and archaeologists with the Museum of Dacian and Roman civilisation of Deva. The action was also opposed, but also excessively publicised, in many cases the supplied information being exaggerate or inaccurate.

Just after the completion of the cutting trees' process a report was drafted. It was submitted to the National Archaeology Commission, which analysed it and approved during the meeting of 23 February 2018. A complaint of Dacica Foundation was also analysed, which argued that the tree's extraction works was negligent, with inadequate means thus seriously damaging the site. At that point still, the scientific responsible of the site, Professor dr. Gelu Florea requested that a commission would be assembled so to examine on the site the effects of the trees' cutting ${ }^{46}$.

Subsequently, the Ministry of Culture and National Identity dispatched on site an expert commision led by $\mathrm{dr}$. Ovidiu T,entea, chairman of the National Commission of Archaeology, who concluded the site was not damaged ${ }^{\otimes}$. The single issue, otherwise mentioned from the start also in the report drawn up by dr. Cătălin Cristescu, regards a tree that fell deviated, while from the impact the crown tip reached the northern wall of the fortification, without yet damaging the monument.

Another issue that requires remedy is that of the lacking management plans of these fortresses, although from their inclusion on the list of world heritage sites many years have passed. A first structured approach of the management plans of UNESCO sites was published in

\footnotetext{
$46 \mathrm{http}: / /$ www.cultura.ro/sites/default/files/inline-files/Rezolutii\%20CNA\%20 23.02.2018.pdf
} 
1993 and republished five years later ${ }^{47}$. In the volume are underlined also management aspects of the listed sites, the work being a reference document even today. According to the Operational Guidelines for the Implementation of the World Heritage Convention of February 2005 and those of July 2017, the general framework of the management system ${ }^{48}$ is very accurately stipulated.

Paragraph 108 mentions that each nominated site must have an adequate management plan or a documented management system that would specify the way in which the exceptional value of the monument would be preserved, preferably by participative means.

Paragraph 109 specifies that the goal of the management system is that to ensure the effective protection of the nominated site for present and future generations.

Paragraph 110 states that an effective management system depends on the type, features and necessities of the nominated site, respectively its cultural and natural context. The management systems may be different according to different cultural views, available resources and other factors. They may include traditional practices, tools for the development of the territory at urban or regional level, respectively other control mechanisms for urbanism, both formal and informal.

Paragraph 111 sets up the common elements of a management system, which include the following:

a. A thorough knowledge, imparted by all interest holders in the nominated site;

b. A cycle of planning, implementing, monitoring, evaluation and response;

c. Involving the partners and interest holders;

d. Development of mechanisms for the involvement and coordination of various activities between different partners and interested parties;

e. Allotment of necessary resources;

f. Consolidation of capabilities;

g. A transparent, quantifiable description of the functioning means of the management system.

Last but not least, paragraph 112 mentions that effective management involves a long term cycle and daily actions for the protection, preservation and presentation of the nominated site.

The management plan must have a structure that would contain essential concepts and a series of key-elements that would contribute to the administration, protection and valuation of the site on long time, both to the benefit of the site and the entire humankind. In the case of the Dacian fortresses the draft of the management plan is crucial for the future of these monuments. The draft of the management plans may use as example those sites which are models of good practice worldwide, such cases being numerous also in European territory.

To the lacking accomplishments of the administrator of the fortress Sarmizegetusa Regia adds the lack of the draft and submitting projects to access European funds designed for historical monuments, although the new funding

\footnotetext{
47 https://glasul-hd.ro/presedintele-comisiei-nationale-de-arheologie-dupao-inspectie-la-regia-problema-reala-o-reprezinta-copacii-care-pot-sa-cadapeste-monumente/

48 FEILDEN/JOKILEHTO 1993.
}

programme, the Operational Regional Programme 20142020, Priority Axis 5. Preservation, protection and durable valuation of the cultural heritage by investment priority 5.1 . Preservation, protection, promotion and development of the natural and cultural heritage, offers substantial amounts for UNESCO monuments. The lack of financial requests on the part of the County Council of Hunedoara is due to fact that from 2013 until present, a series of issues and mandatory aspects that would allow submitting financing projects was not resolved. Among count the lack of a Regional Urban Plan, the documentation to approve intervention works (D.A.L.I.), completed in the autumn of $2018^{49}$, or of a financial analysis and forecast plan, but also of a management and marketing plan of the site, all necessary to place a financing request with real chances of success. Given the complexity and duration of these documents, there are few chances to obtain financing for Sarmizegetusa Regia from European funds until 2020. In what the other fortresses are concerned, it is impossible to obtain such financing by competition for their preservation, protection and promotion even from national institutions and entities.

It is certain that, although these monuments of universal interest are in the Romanian state heritage, we note that the Ministry of Culture and National Identity, designed to protect the cultural heritage, behaves in complete disdain and disinterest for these fortresses, although it holds every leverage to obtain financial resources for their preservation, protection, restoration, research and promotion. The inactivity and lack of action of the Ministry of Culture and National Identity, which does not take specific measures so that these fortresses be transferred under the administration of other institutions, is revolting and evidences lack of vision, responsibility and respect for these unique monuments that belong to the universal heritage $\mathrm{e}^{50}$. On the other hand, county authorities lack determination and coherence before the decisions taken by the Ministry of Culture and National Identity and its representatives in the territory, based on incoherent and contradictory legislation which leads to great difficulty in administration. There have been also noted recent dysfunctions in the relation between the management of the administration of the historical monument of Sarmizegetusa Regia and the management of the County Council of Hunedoara and those in the County Directorate of Culture of Hunedoara on the other hand ${ }^{51}$. Last but not least, one should mention the reproaches concerning the management of the site of Sarmizegetusa

\footnotetext{
9 Cf. Operational Guidelines for the Implementation of the World Heritage Convention https://whc.unesco.org/archive/opguide05-en.pdf; https://whc. unesco.org/en/guidelines/

50 The representation of the County Council of Hunedoara stated the assessed amount was necessary for the reconstruction, protection and preservation works of Sarmizegetusa Regia, rising to 60 million Euros, but also that after the completion of the approval documentation, the institution would search for financing sources for the preservation and protection of the UNESCO site. See to this effect http://zhd.ro/eveniment/politica-administratie/protejareasitului-sarmizegetusa-regia-are-nevoie-de-60-milioane-de-euro/; https://adevarul.ro/locale/hunedoara/lucrarile-sarmizegetusaregia-fost-evaluate-60-milioane-euro-suma-fabuloasa-acoperi-costurileconservarii-protejarii-cetatii-dacice-1_591492945ab6550cb802ba63/index. $\underline{\mathrm{html}}$

51 Not even in the year of the Great Union Centenary this Ministry did nothing to remedy the situation of these monuments and to promote their cultural value.
} 
Regiaa and the archaeologists excavating there, emerging in some newspapers, publications or web pages. Sometimes, some information in these texts is inflated, misinterpreted, inaccurate or complete bogus. We believe that the numerous existing issues, especially in the case of the other five unmanaged fortresses, should join, and efforts and actions carried out for both their resolution and the benefit of these sites. The policy of interferences and disputes on a series of topics that lack meaning, like the trees' cutting in 2018, aids nothing, but rather complicates things, and obviolsuyt does not solve the real issues of these sites. Instead of losing time by controversies, it would be better if we joined forces and request in one voice, based on the rules and regulations in force, the urgent resolution of existing issues, but also the support by a series of specific actions of volunteering, people coming to aid in various forms the protection, promotion and research of these sites.

Also, concerted efforts should be made for the draft of a new law for the UNESCO sites in Romania. This should include the establishment of an integrated system of regulations, in correlation with UNESCO recommendations, but also the correlation of direct protection measures with urbanism regulations. Also, it should include a series of aspects like the monitoring and administration of the sites, and the involvement of local authorities, owners, academic community and civil society. Its approval would significantly contribute to the improvement of the sites' management in Romania. Debates and discussion for the draft of a document of policies for the preservation and promotion of the fortresses on the UNESCO World heritage site's List would also be beneficial, as well as the establishment of a model for heritage management, according to the need and peculiarities of each site.

Past the above, the efforts on those involved in the management, protection, enhanced use or research of Sarmizegetusei Regia is commendable and worthy of support, both by local and central authorities as well as the academic environment and civil society ${ }^{52}$. The positive advances in the management of Sarmizegetusa Regia in the last six years, with mainly beneficial results in the form of the change for the better of the site's image and its promotion, even though hindrances are still present, give us hope that in a short while, the other fortresses in this fortified complex would also benefit of a treatment to the extent of their universal value.

There is still much work to be done and one may not speak of perfect or soundproof management model of Sarmizegetusa Regia. Nevertheless, we are confident that gradually, any dysfunctionality would disappear, errors and misaccomplishments would be increasingly less, despite the site complexity, while the gathered experience and efforts of those involved for the good of this site would be increasingly

\footnotetext{
52 Cf. https://romanialibera.ro/social/hunedoara-administratorulcetatii-sarmizegetusa-regia-a-demisionat-754802;

http://zhd.ro/eveniment/politica-administratie/protest-ziuaa-patra-ce-spun-fostii-sefi-ai-consiliului-judetean-hunedoara-desprevladimir-brilinsky/;

http://www.stiridinvest.ro/administratorul-sarmizegetusa-regiaa-demisionat-acuzand-pesedizarea-acestui-loc/;

http://www.ziare.com/deva/stiri-actualitate/bobora-1-a-convinspe-vladimir-brilinsky-sa-renunte-la-protest-7482238
}

greater.

In conclusion, one can only say woe to the people unable to protect and value the cultural heritage inherited from previous generations, unaware that the cultural heritage is an important link in the durable development of the society, providing unquantifiable benefits. On the other hand, the protection of the historical monuments should exceed the limits of cultural or educational importance and become a long term priority for Romania.

\section{ACKNOWLEDGMENTS}

This study was drafted within project Preservation by development of sustainable strategies for a better protection of the UNESCO World Heritage Sites from Romania, - PN-III-P4ID-PCE-2016-0737, funded by CNCS-UEFISCDI.

\section{REFERENCES}

\section{BÂRCĂ 2018}

Bârcă, V., Câteva observații privind administrarea Cetăților dacice din Munții Orăștiei înscrise în lista patrimoniului mondial UNESCO / A few notes on the management of the Dacian fortresses from the Orăștiei Mountains on the list on UNESCO world heritage sites, Plural. History-Culture-Society 6/2, 2018, 78-111.

\section{BÂRCĂ 2018a}

Bârcă, V., Aspecte pozitive și negative în administrarea Cetăților dacice din Munții Orăștiei înscrise în lista patrimoniului mondial UNESCO, Simpozionul "Patrimoniul cultural al județului Iași: evidență, protejare și valorificare”, Iași, 30-31 October 2018.

BERECKI/CZAJLIK/SOÓS 2012

Berecki, S./Czajlik, Z./Soós, Z. (eds.), Historical landscapes. Aerial Photographs of Transylvanian Archaeological Sites and Monuments, CMM, I (Budapest-Târgu Mureş: L'Harmattan-Mega).

\section{DAICOVICIU/FERENCZI/GLODARIU}

Daicoviciu, H./Ferenczi, Șt./Glodariu, I., Cetăți și așezări dacice în sud-vestul Transilvaniei (Bucharest: Scientific and Encyclopaedic Publishing House).

FEILDEN/JOKILEHTO 1993

Feilden, B./Jokilehto, J., Management Guidelines for World Heritage Cultural Sites (Rome: ICCROM).

\section{FLOREA 2011}

Florea, G., Dava et oppidum. Débuts de la genes e urbaine en Europe au deuxieme âge du Fer (Cluj-Napoca: Acad. Roumaine, Centre d'Études Transylvaines).

FLOREA 2017

Florea, G., Excavations in Sarmizegetusa Regia: Recent Results and Perspectives. In: Mitthof, F., Schörner, G. (ed.), Columna Traiani - Traianssäule. Siegesmonument und Kriegsbericht in Bildern. Beiträge der Tagung in Wien anlässlich des 1900. Jahrestages der Einweihung, 9.-12. Mai 2013 [TYCHE Sonderband 9] (Viena: Verlag Holzhausen), 363-368.

\section{GERSTER 2003}

Gerster, G., Flug in die Vergangenheit. Archäologische Stätten der Menschheit in Flugbildern, Charlotte Trumpler (ed.) (München: Schirmer-Mosel). 


\section{GHEORGHIU 2005}

Gheorghiu, G., Dacii pe cursul mijlociu al Mureșului (sfârșitul sec. II a. Chr. - începutul sec. II p. Chr.) (ClujNapoca: Mega).

GLODARIU 1983

Glodariu, I., Arhitectua dacilor - civilă și militară (sec. II a. Chr. - 1 p. Chr.), (Cluj-Napoca: Dacia).

GLODARIU/MOGA 1989

Glodariu, I./Moga, V., Cetatea dacică de la Căpâlna (Bucharest: the Scientific and Encyclopaedic Publishing House).

MATEESCU 2012

Mateescu, R., Istoriile unui templu (Cluj-Napoca: Mega).

MATEESCU 2017

Mateescu, R., Digging and Excavating at Sarmizegetusa Regia in the 19th and 20th Century. In: Mitthof, F., Schörner, G. (ed.), Columna Traiani Traianssäule. Siegesmonument und Kriegsbericht in Bildern. Beiträge der Tagung in Wien anlässlich des
1900. Jahrestages der Einweihung, 9.-12. Mai 2013 [TYCHE Sonderband 9] (Viena: Verlag Holzhausen), 357-362.

MATEESCU/PUPEZĂ 2016

Mateescu, R./Pupeză, P., Elemente de arhitectura militară / Aspects of the military architecture. In: Neamţu, C., Florea, G., Gheorghiu, G., Bodó, C. (eds.), Când viața cotidiană antică devine patrimoniu UNESCO - Incursiuni dacice în spațiul virtual (ClujNapoca: Only One Publishing House), 221-249.

NEAMŢU/FLOREA/GHEORGHIU/BODÓ 2016 Neamţu, C./Florea, G./Gheorghiu, G./Bodó, C. (eds.), Când viața cotidiană antică devine patrimoniu UNESCO - Incursiuni dacice în spațiul virtual (Cluj-Napoca: Only One).

\section{VASILESCU 2018}

Vasilescu, S. A., Bune practici de administrare la Sarmisegetusa Regia, Seminar „Managementul siturilor UNESCO din România”, Bucharest, 30-31 March 2018. 


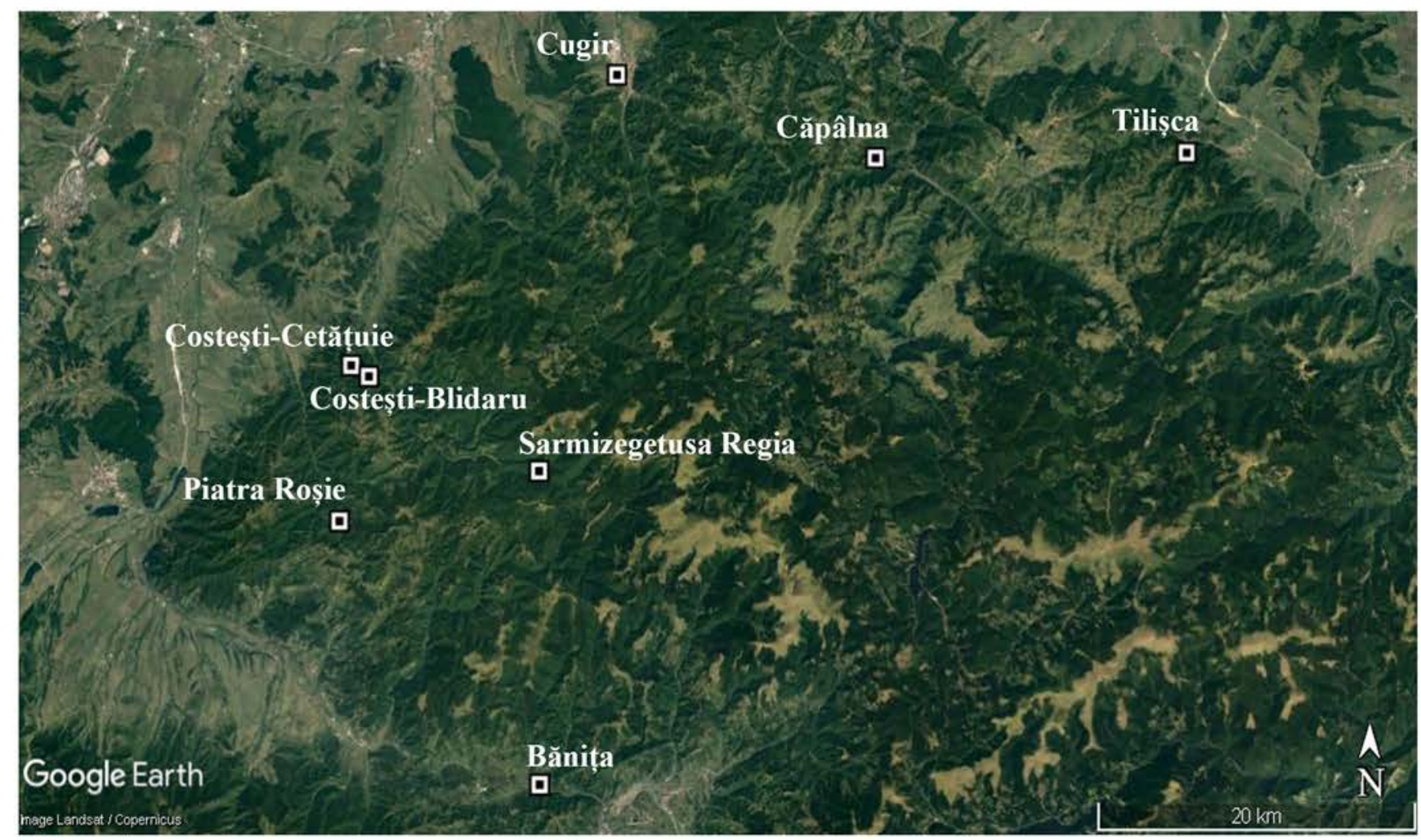

1

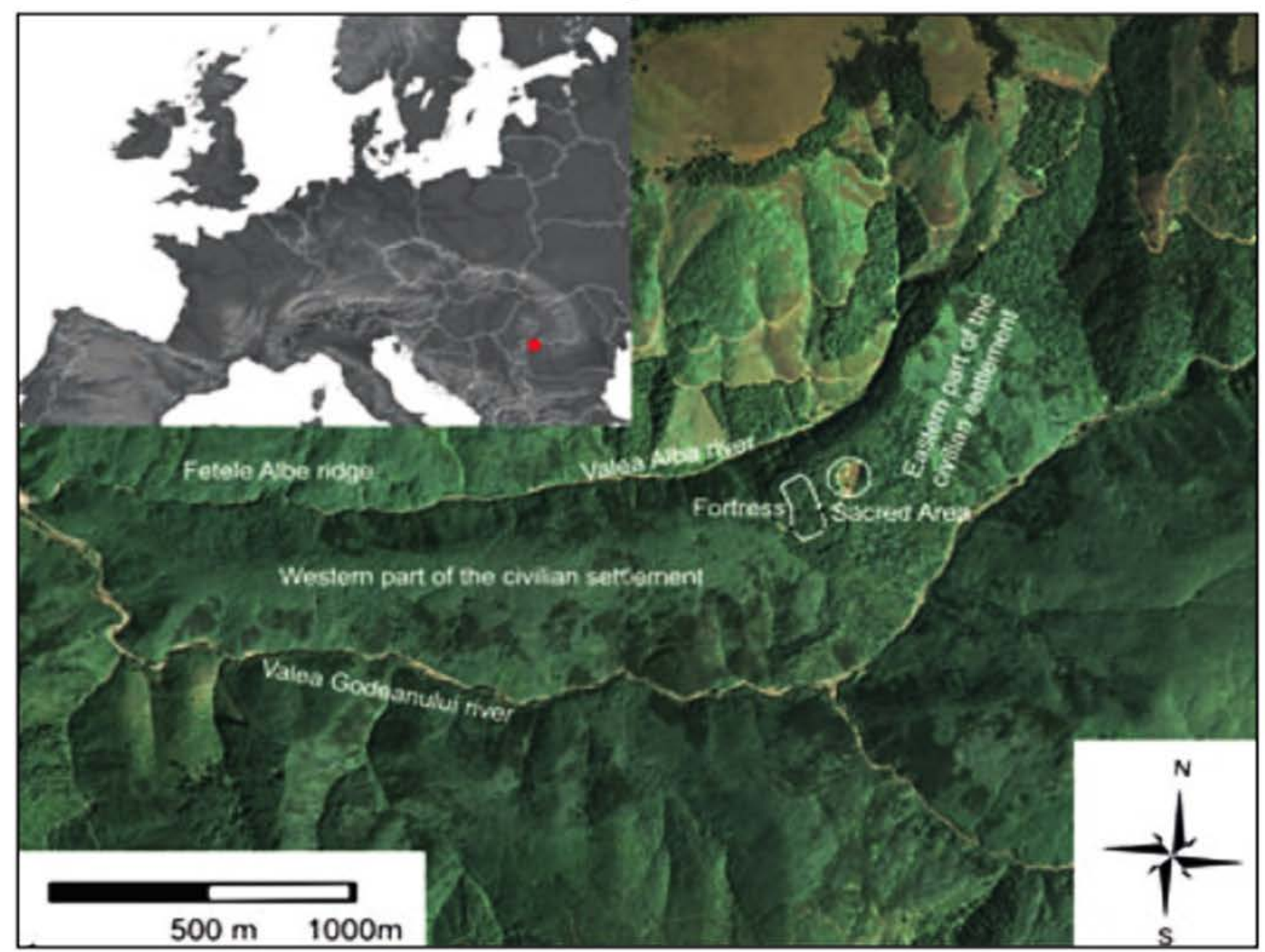

2

Pl. 1. Map with the location of the Dacian fortresses included among the UNESCO World Heritage sites (1); Sarmizegetusa Regia. Satellite map (2) (2 - after FLOREA 2017). 


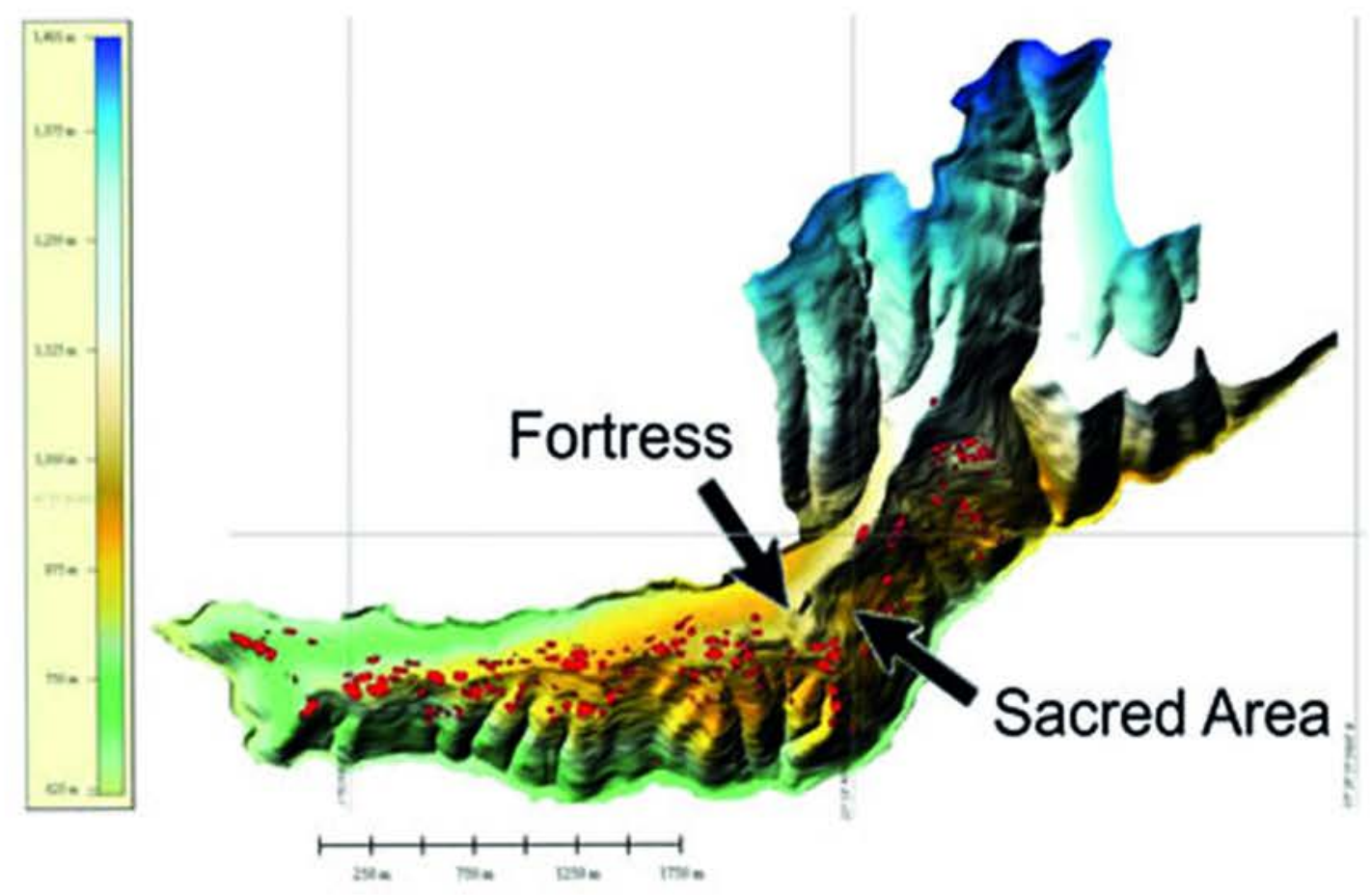

1

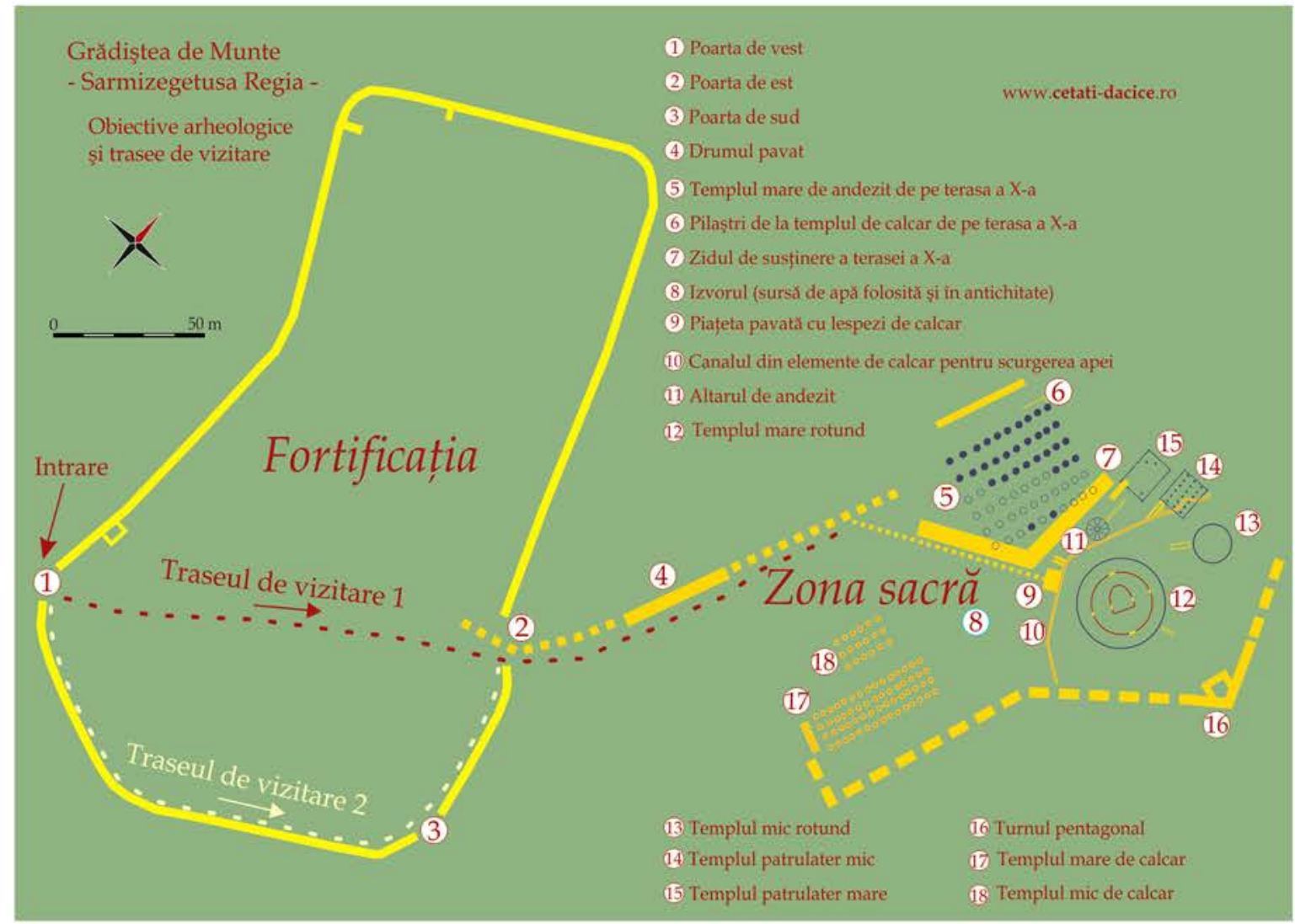

2

Pl. 2. Sarmizegetusa Regia. General archaeological map of the site (1) (after FLOREA 2017); Plan with the archaeological points and visiting routes (2) (after Răzvan Mateescu). 


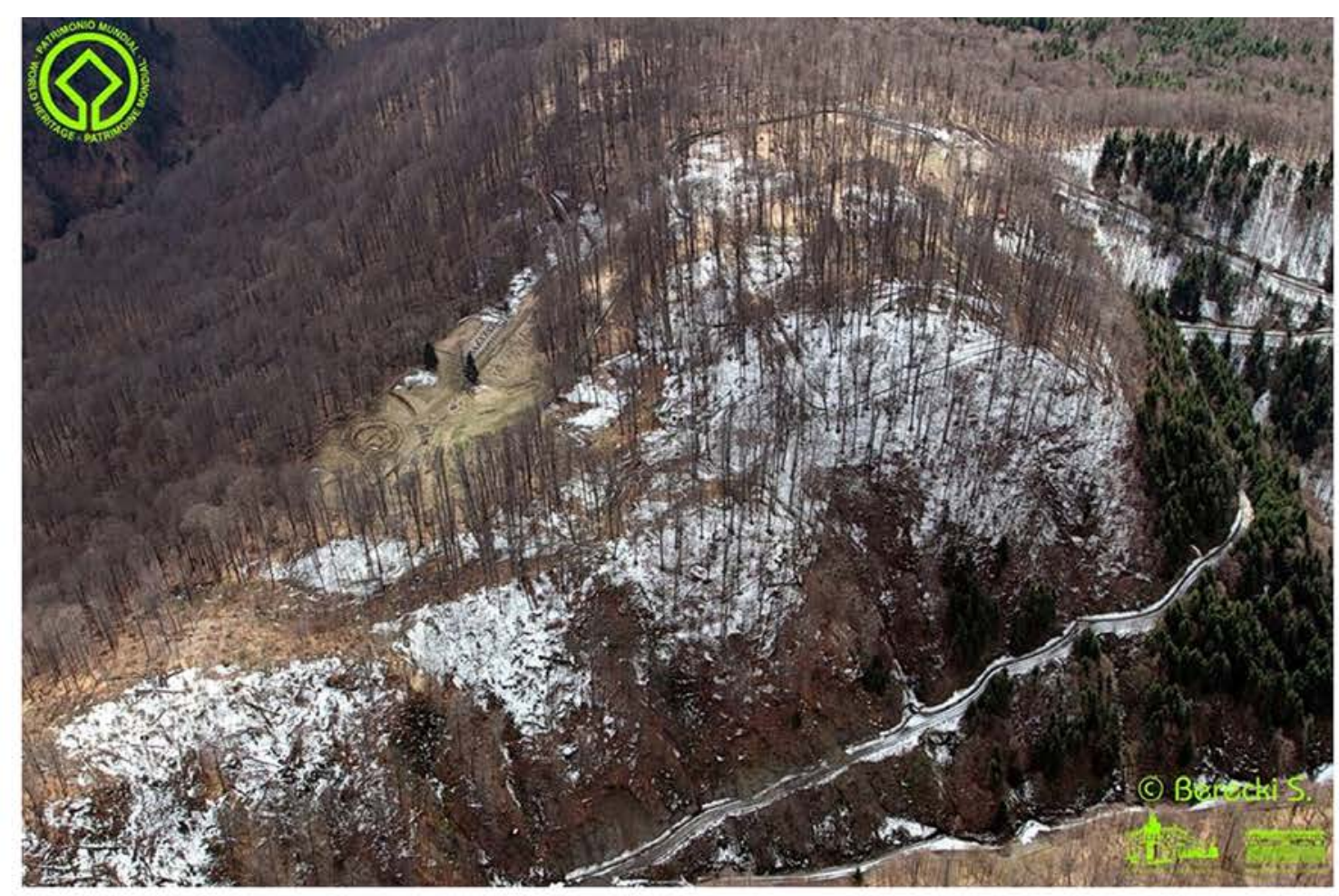

1

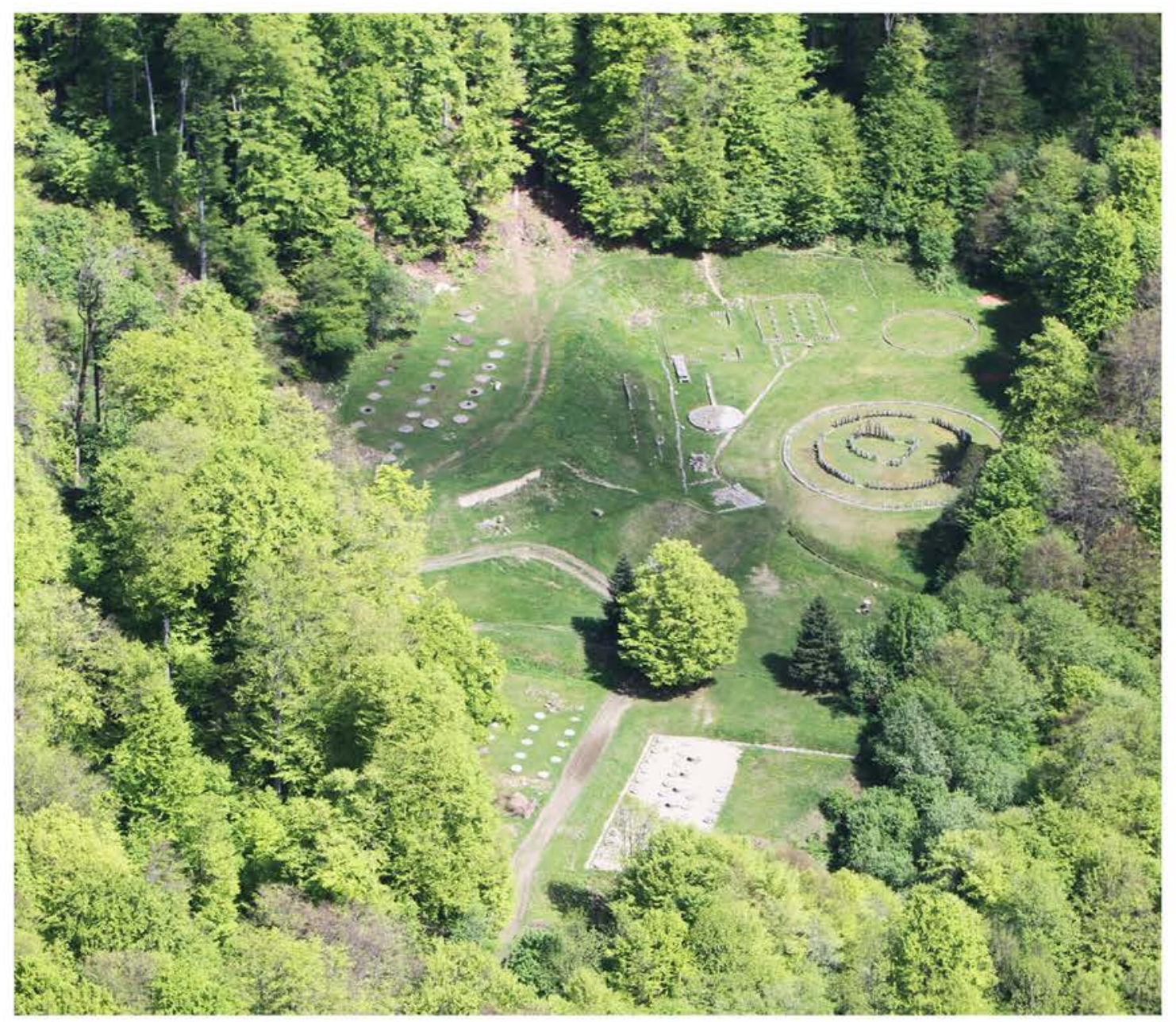

PI. 3. General aerial view of the Sarmizegetusa Regia fortress (1) (photo Sándor Berecki, 2018); Aerial view of the sacred area (2) (after MATEESCU 2012). 


\section{Studies}

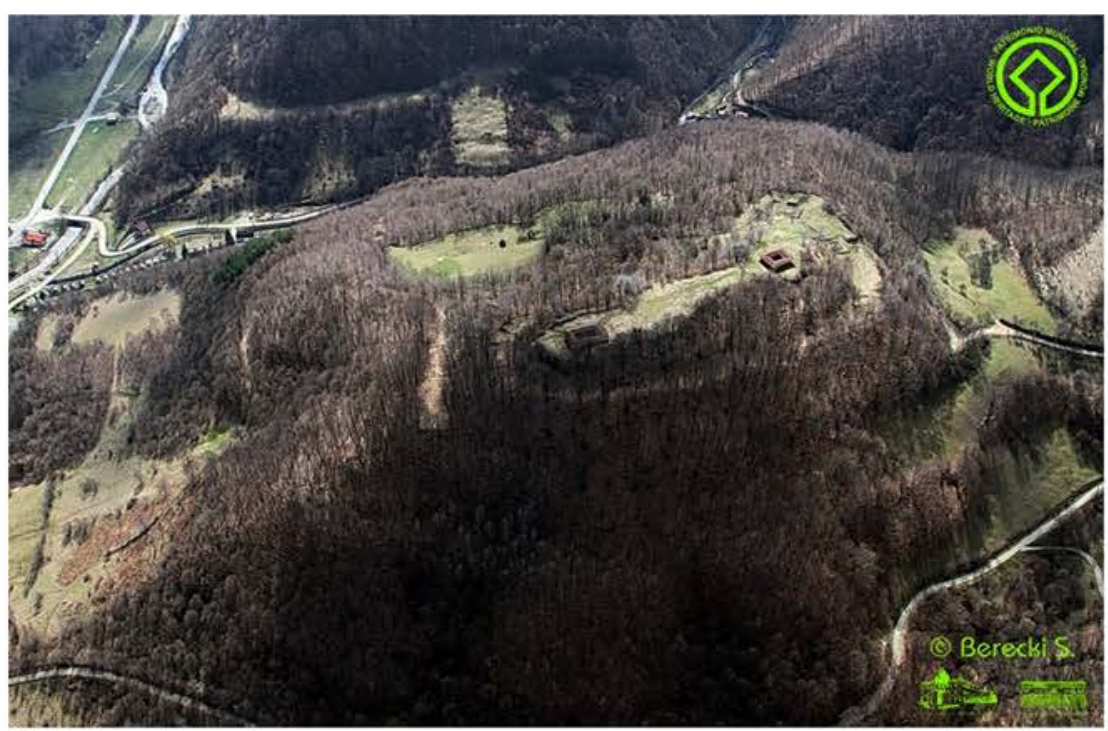

1

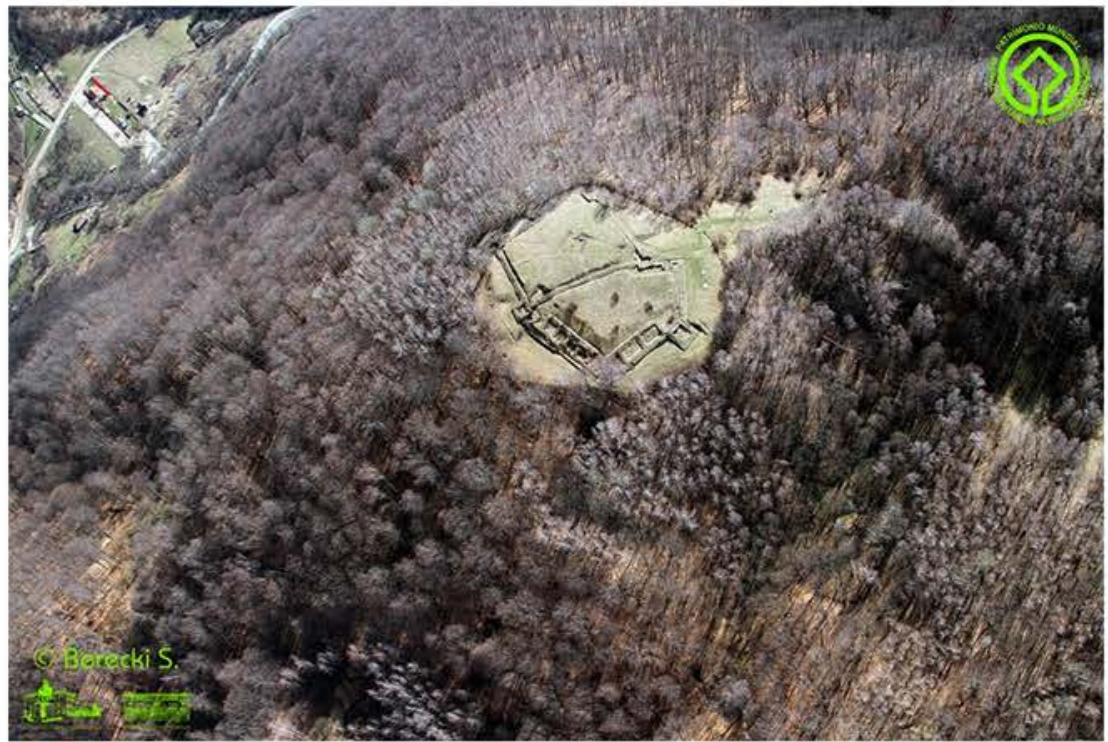

2

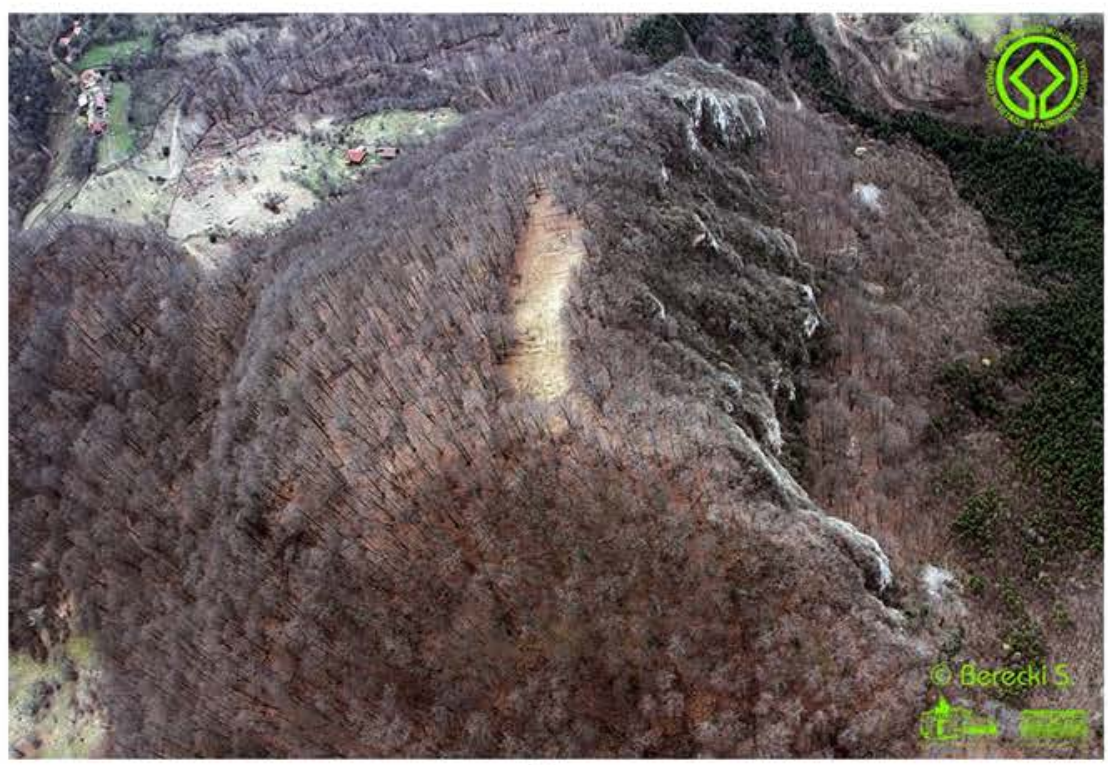

3

PI. 4. Aerial view of the Costești-Cetățuie (1), Costești-Blidaru (2) and Piatra Roșie fortresses (3) (photo Sándor Berecki, 2018). 


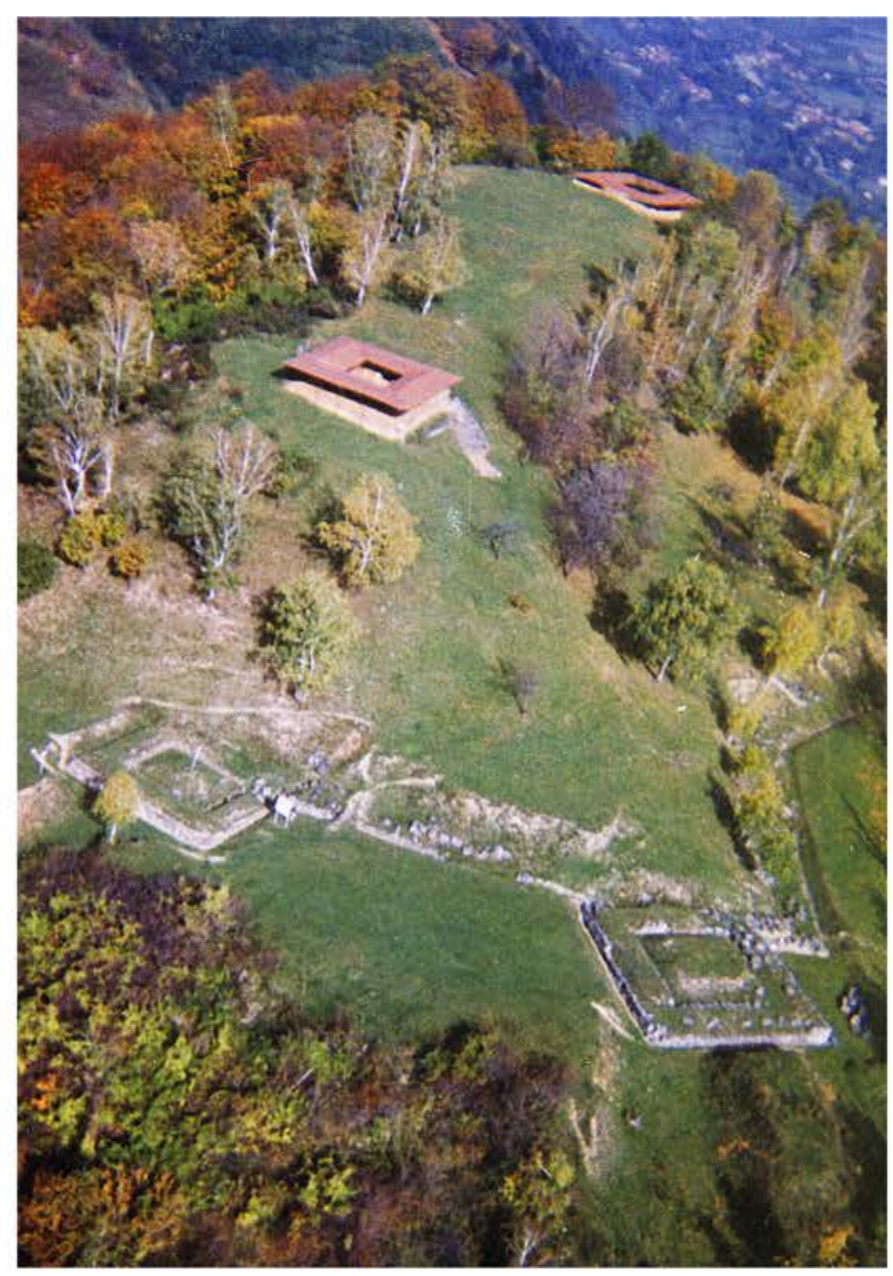

1

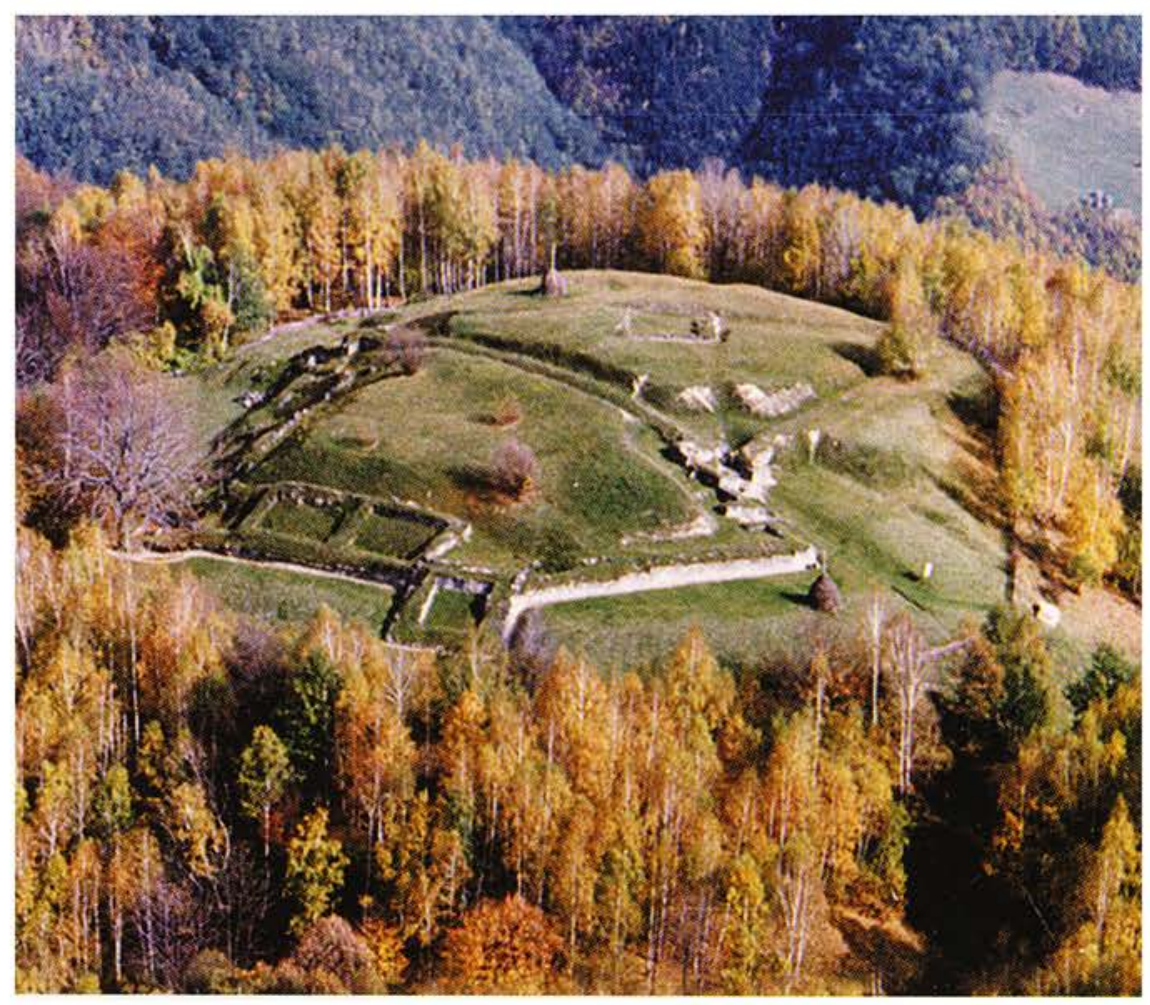

2

Pl. 5. Aerial view of the Costești-Cetățuie (1) and Costești-Blidaru (2) (photo Eugen Pescaru). 
Studies

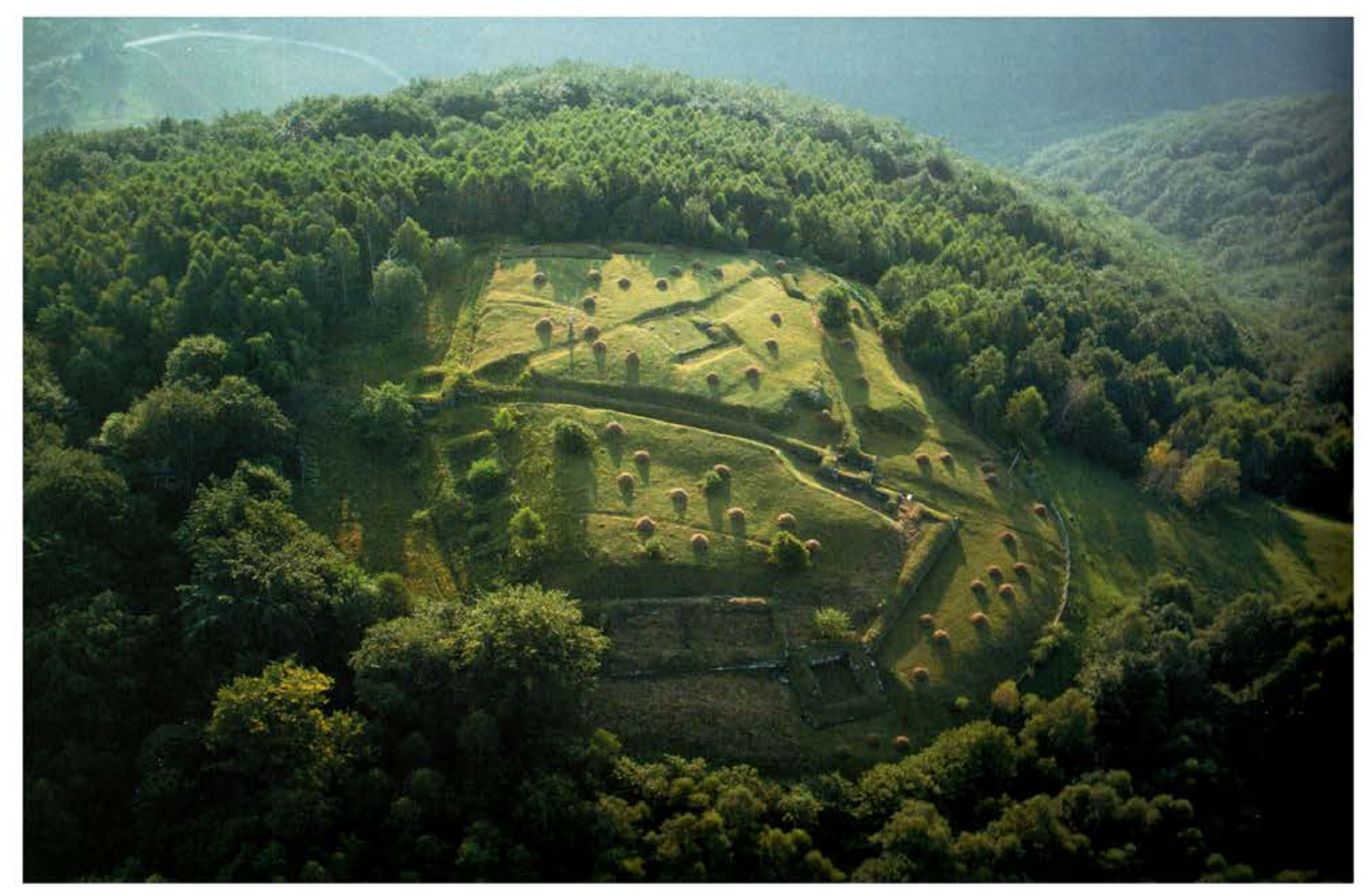

1

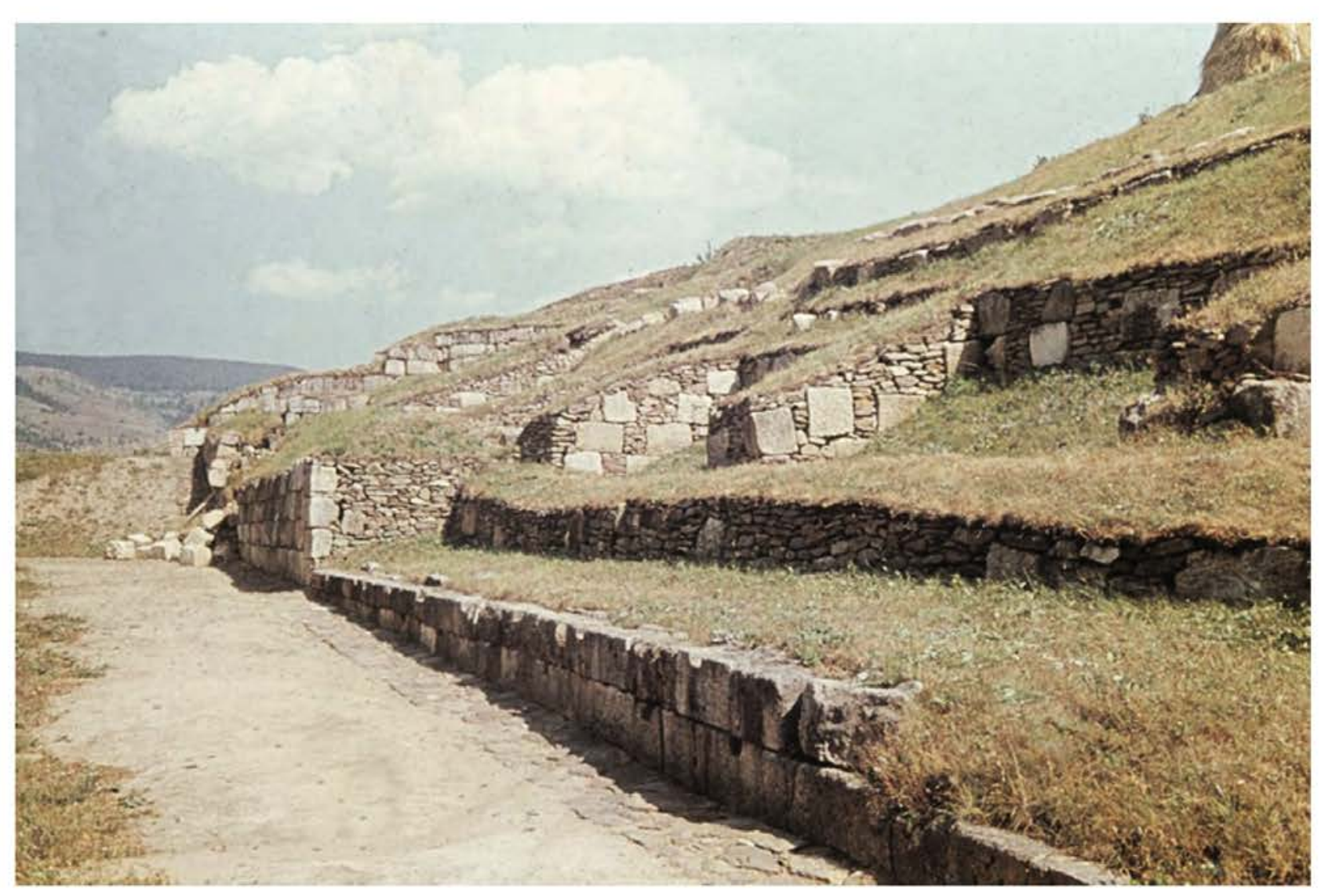

2

\footnotetext{
Pl. 6. Aerial view of the Costești-Blidaru (1) (after GERSTER 2003); wall of limestone blocks and mica schist pieces from Costești-
Blidaru (2) (after MATEESCU/PUPEZĂ 2016).

Pl. 6. Aerial view of the Costești-Blidaru (1) (after GERSTER 2003); wall of limestone blocks and mica schist pieces from Costești-
Blidaru (2) (after MATEESCU/PUPEZĂ 2016).
}

\section{政 \\ . .

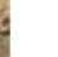

.

.
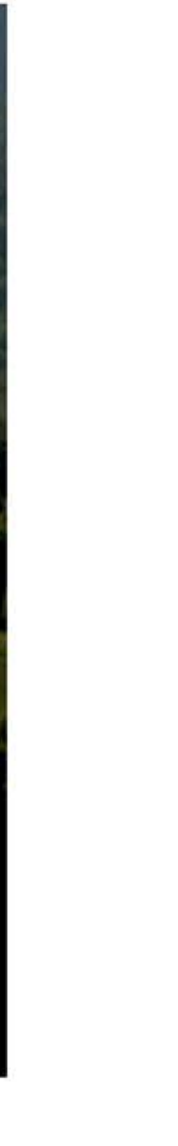

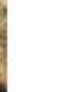

lof Ancient History and Archaeology No.6.1/2019 


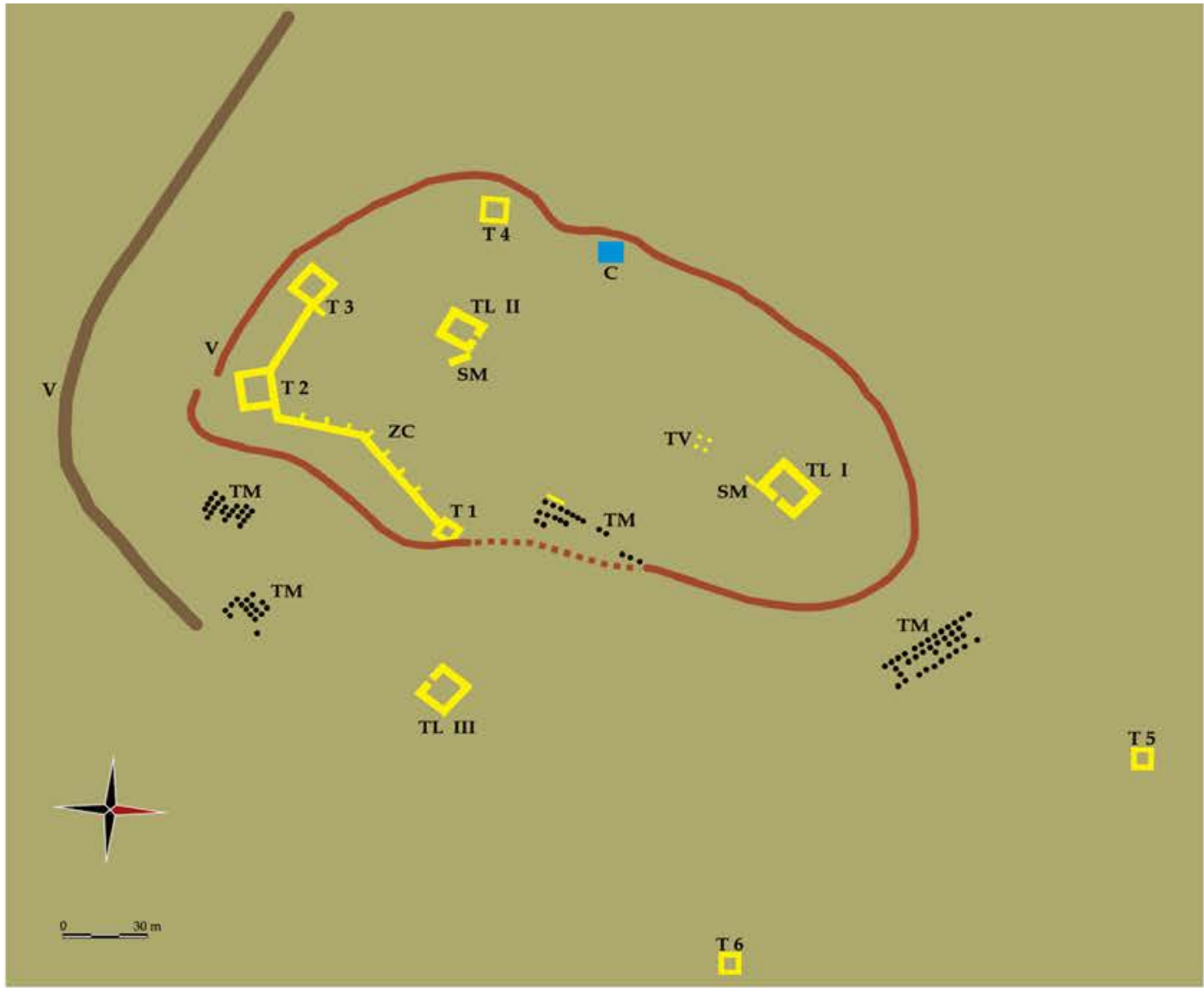

1

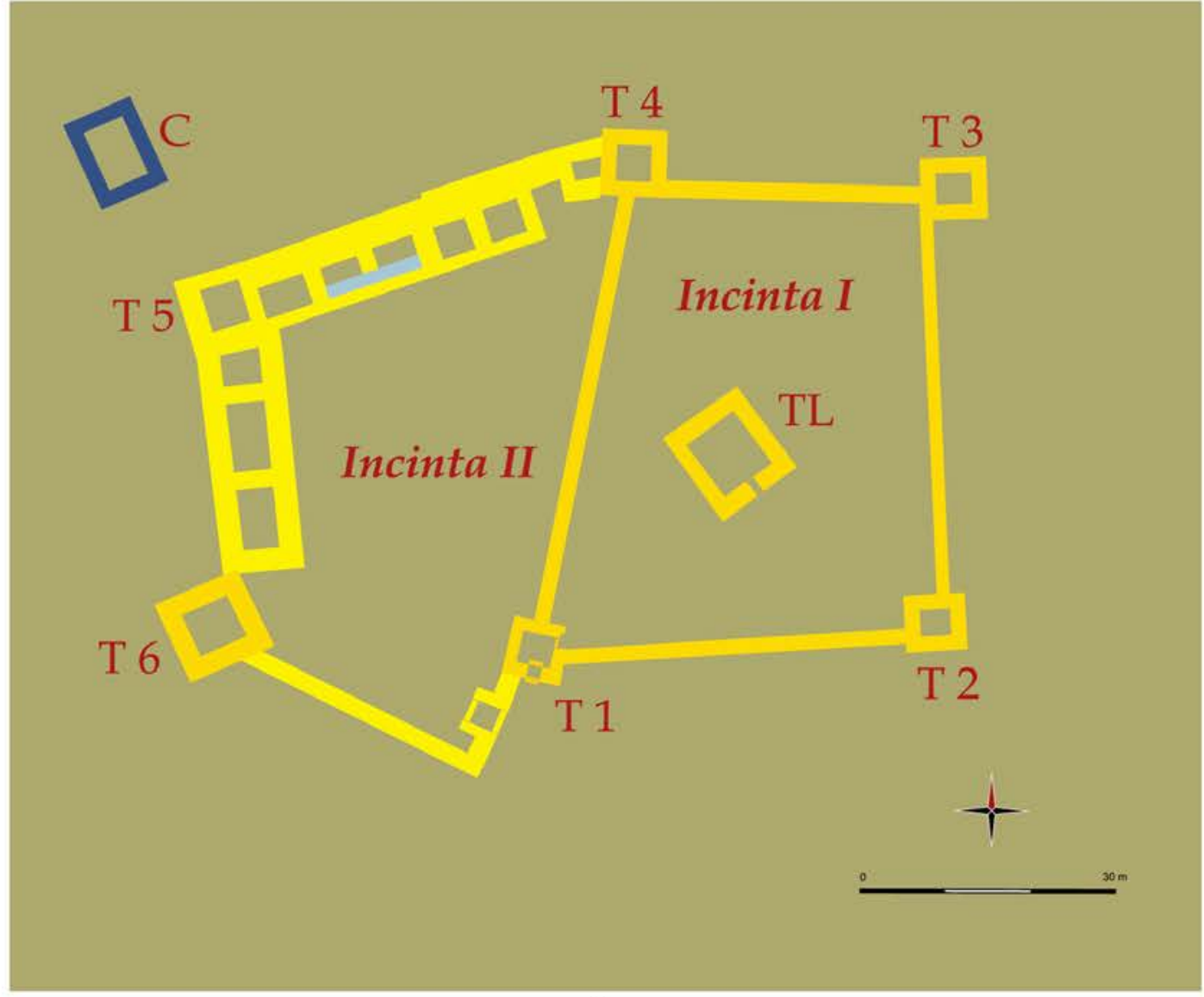

2

PI. 7. Plan of the Costești-Cetățuie (1) and Costești-Blidaru (2) fortresses (after MATEESCU/PUPEZĂ 2016). TL - tower house; T tower; TM - temple; TV - guard tower; C - cistern; ZC - buttresses wall; SM - monumental stairs; $\mathbf{V}$ - bulwark. 


\section{Studies
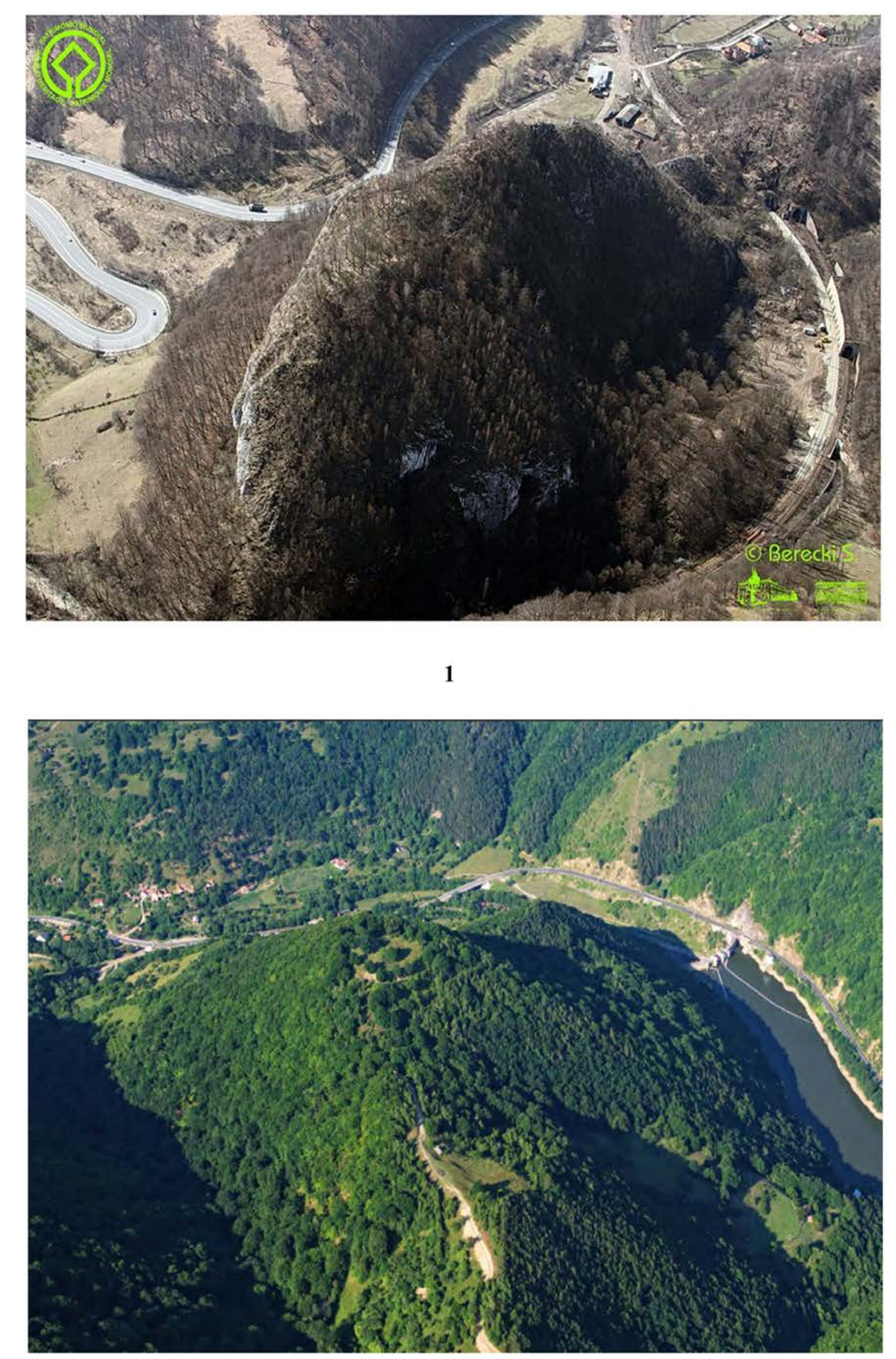

PI. 8. Aerial view of the Bănița (1) (photo Sándor Berecki, 2018) and Căpâlna fortresses (2) (after BERECKI/CZAJLIK/SOÓS 2012).

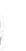

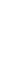

\section{.}

Pl. Aeialview of hén

ournal of Ancient History and Archaeology 

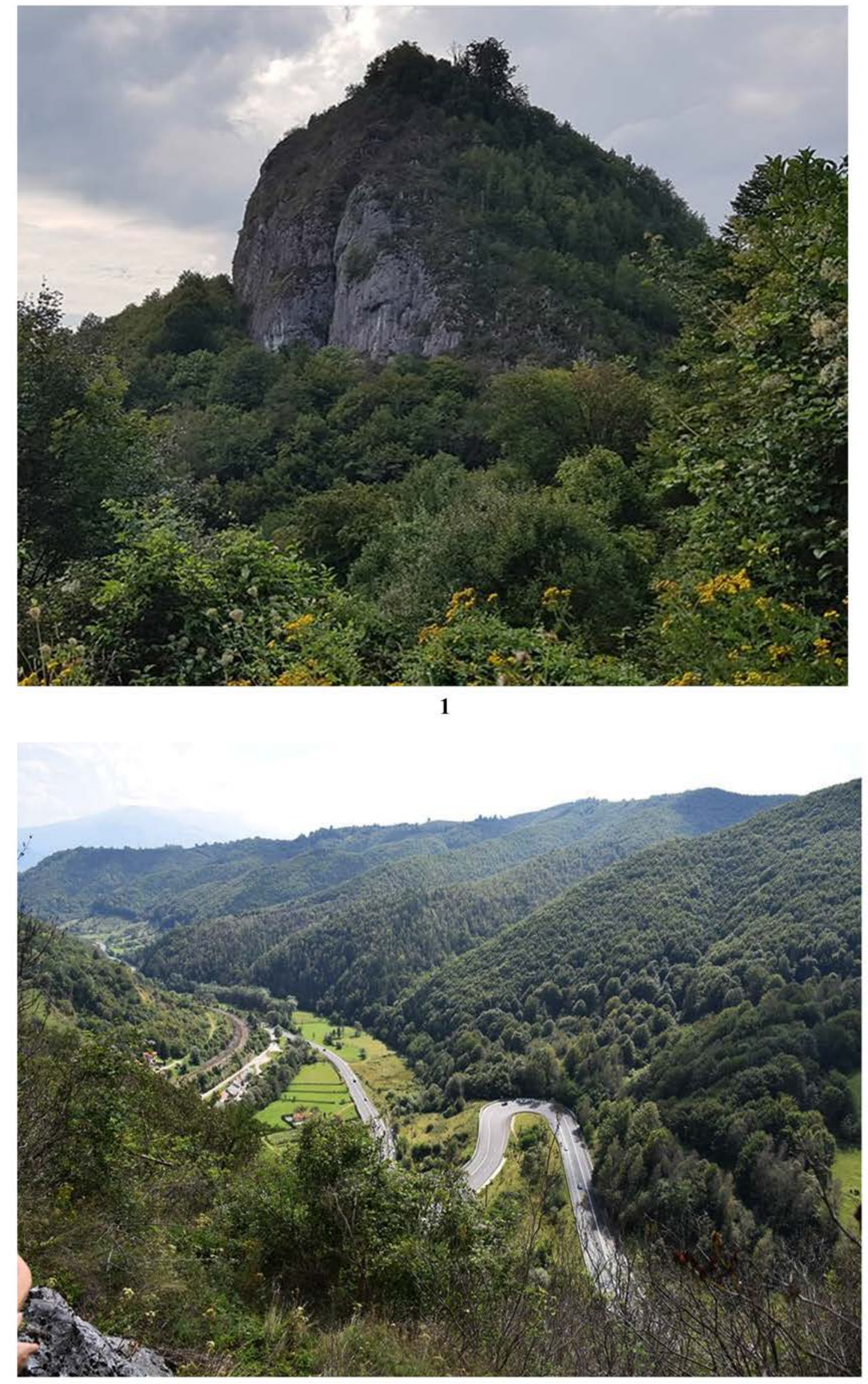

PI. 9. Cetății Hill (Bolii Hill) on which lies the Bănița fortress (1); view from the fortress of Bănița (2) (photo Sergiu Musteață, 2018). 
Studies

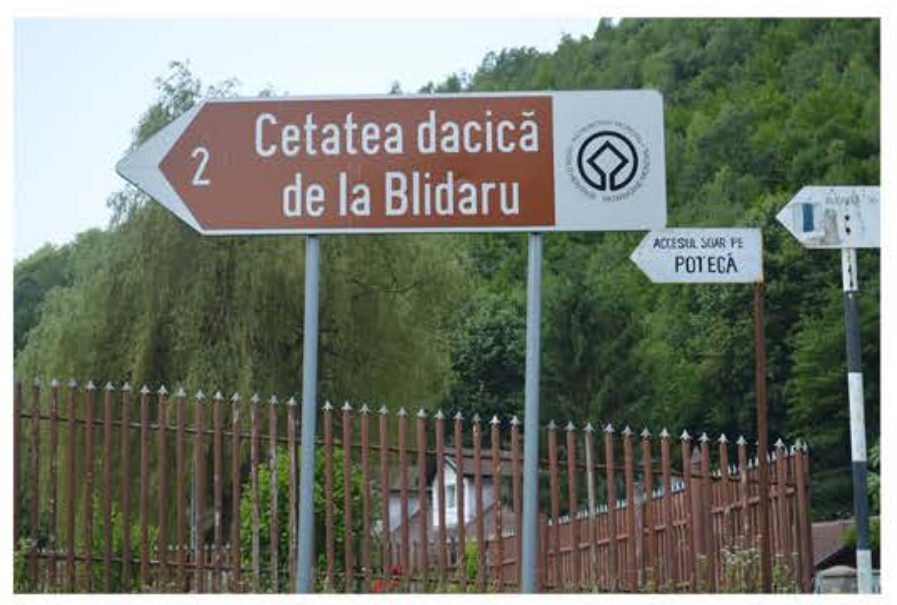

1

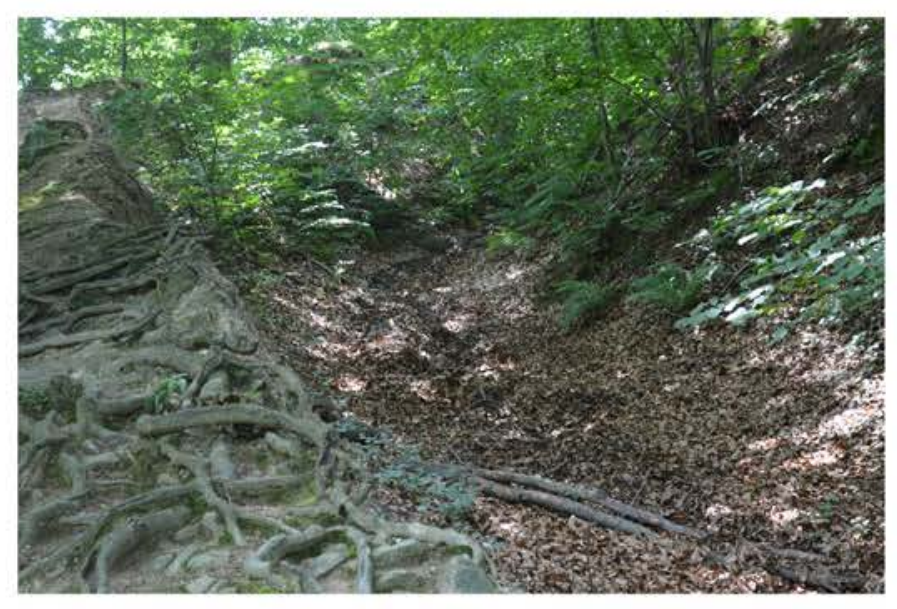

3

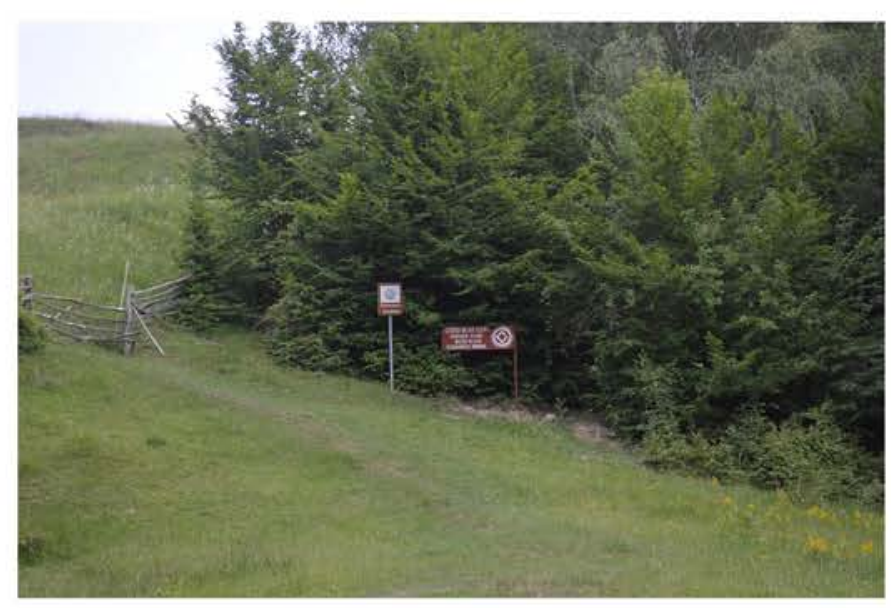

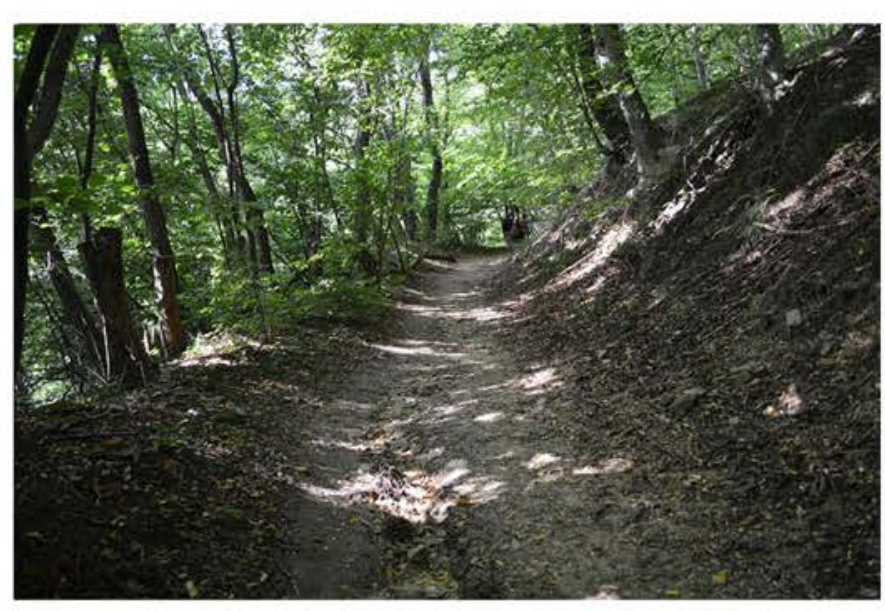

2

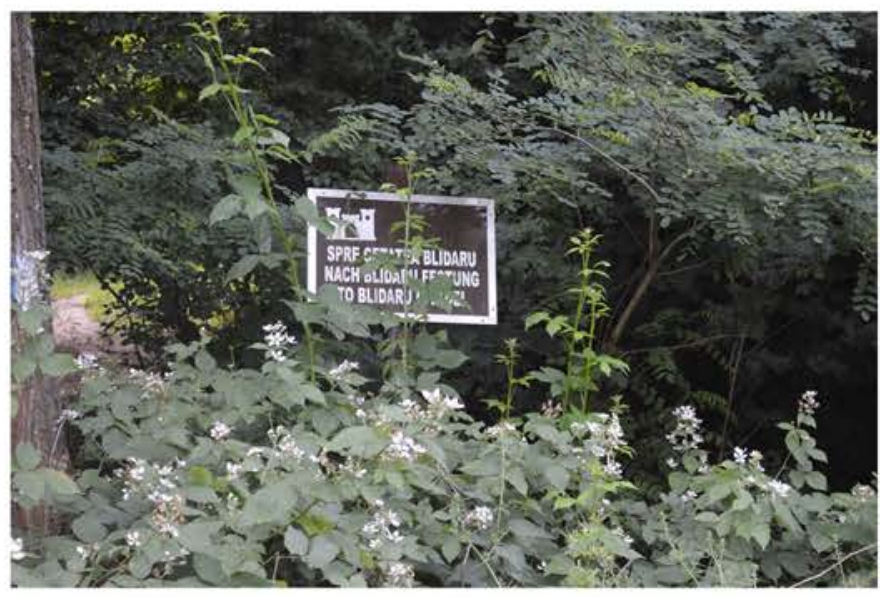

4

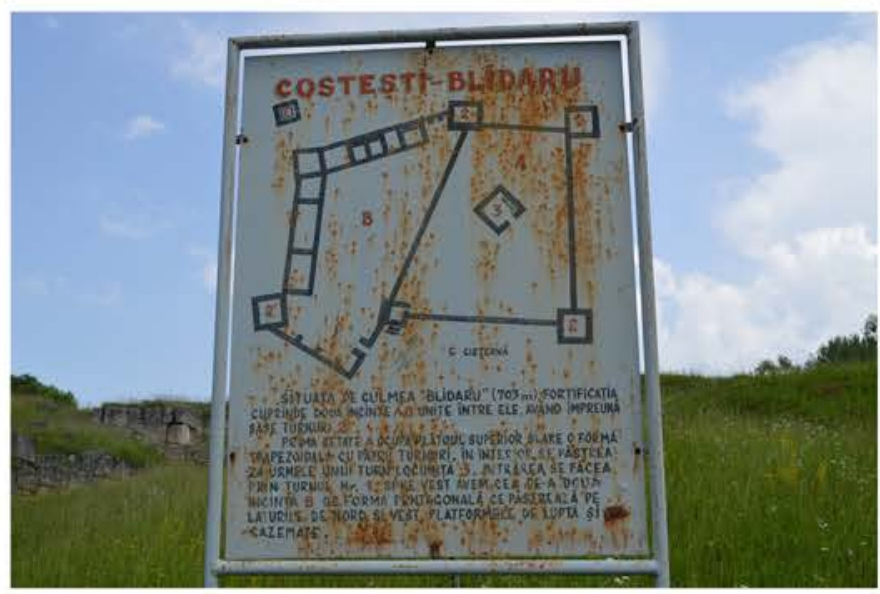

6

Pl. 10. Signalling panels $(\mathbf{1}, \mathbf{4}, \mathbf{5})$, access road (2-3) and explanatory panel (6) for the Costesti-Blidaru fortress (photo Vitalie Bârcă, 2018). 


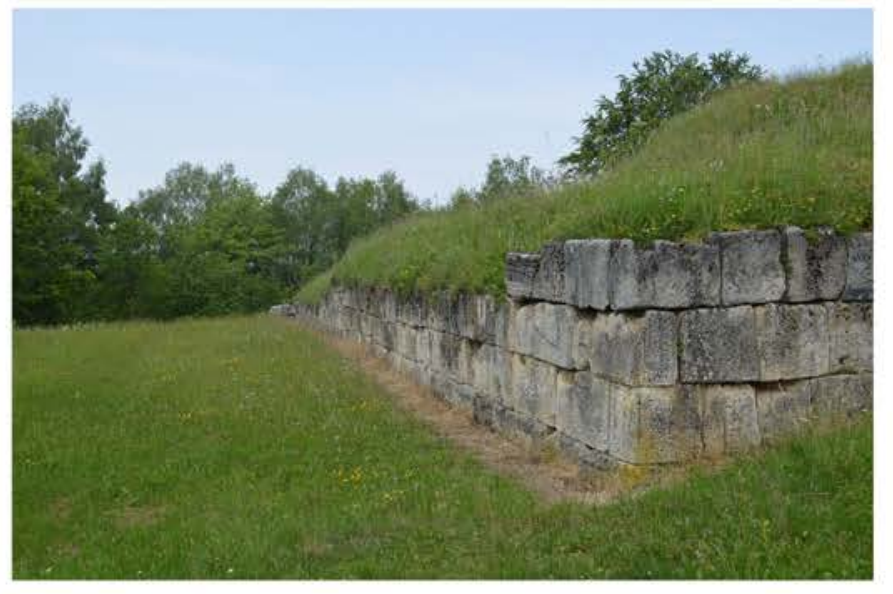

1

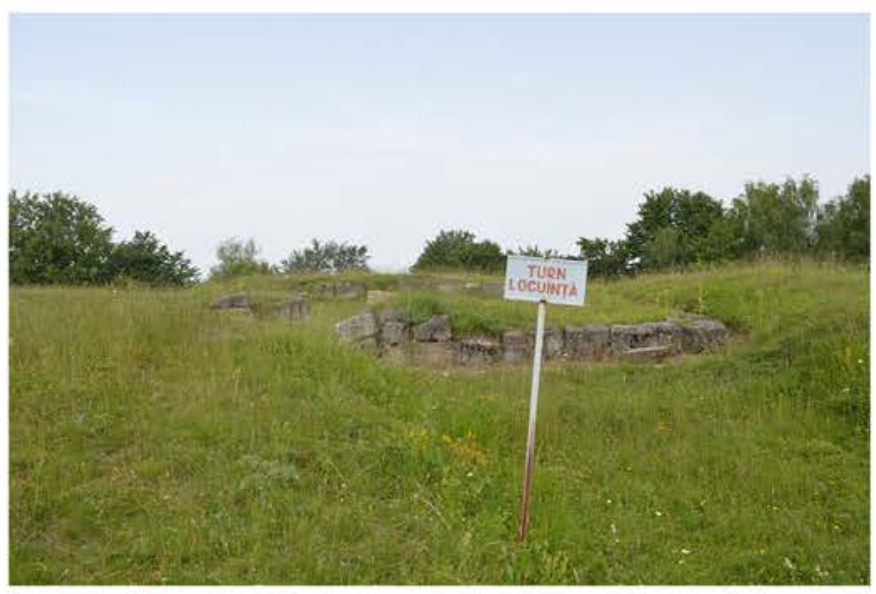

3

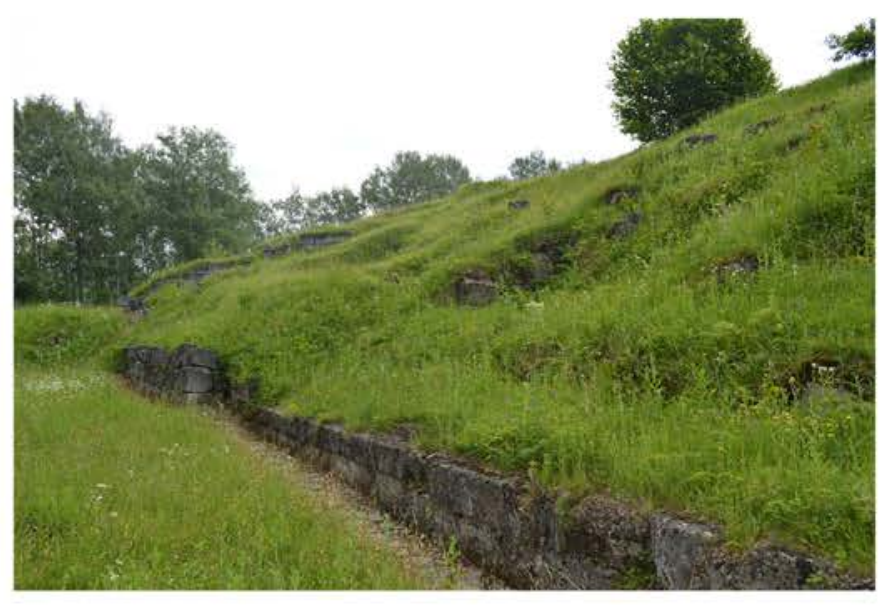

5

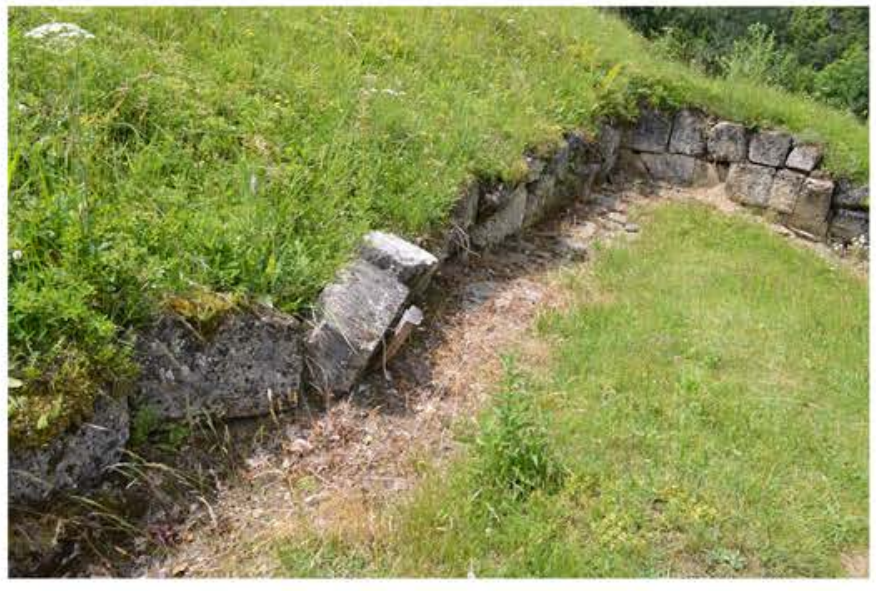

2

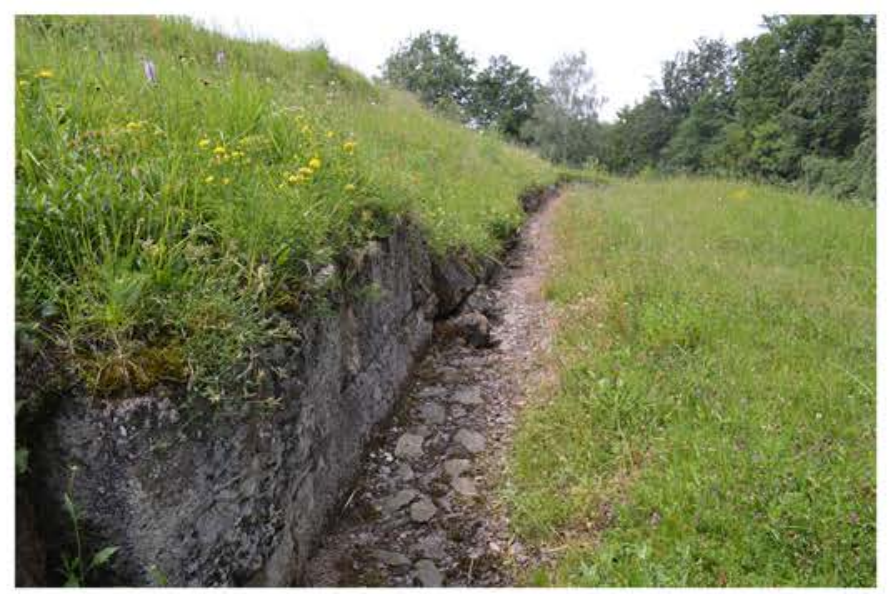

4

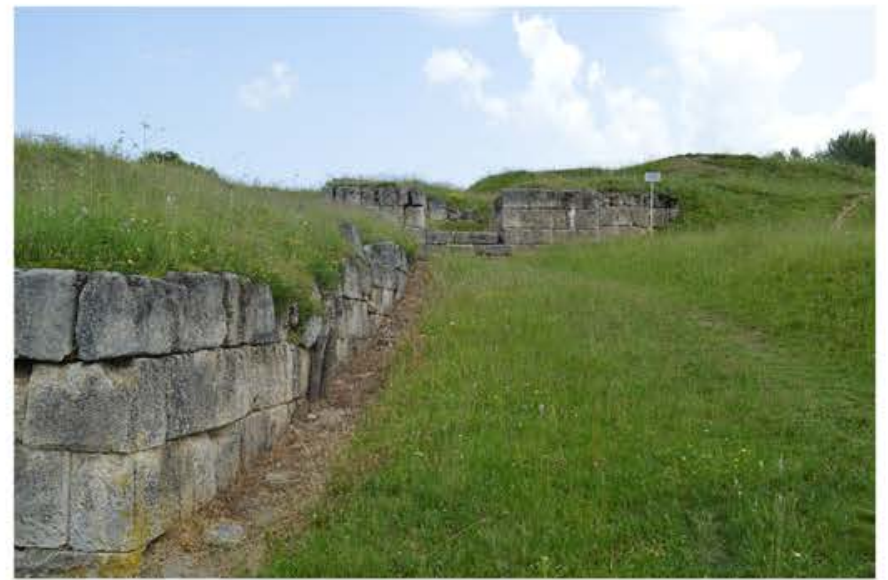

6

Pl. 11. Images with walls and tower-house from Costești-Blidaru (photo Vitalie Bârcă, 2018). 
Studies

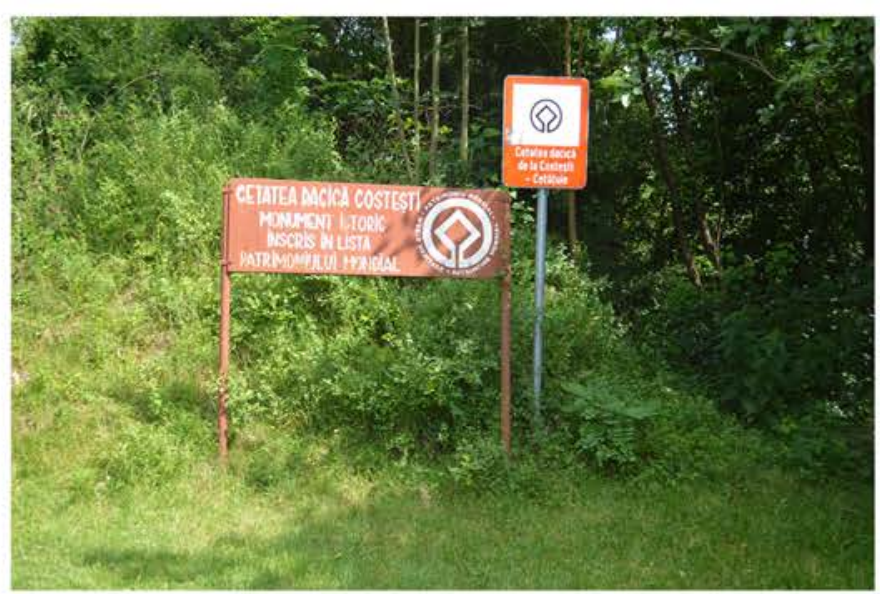

1

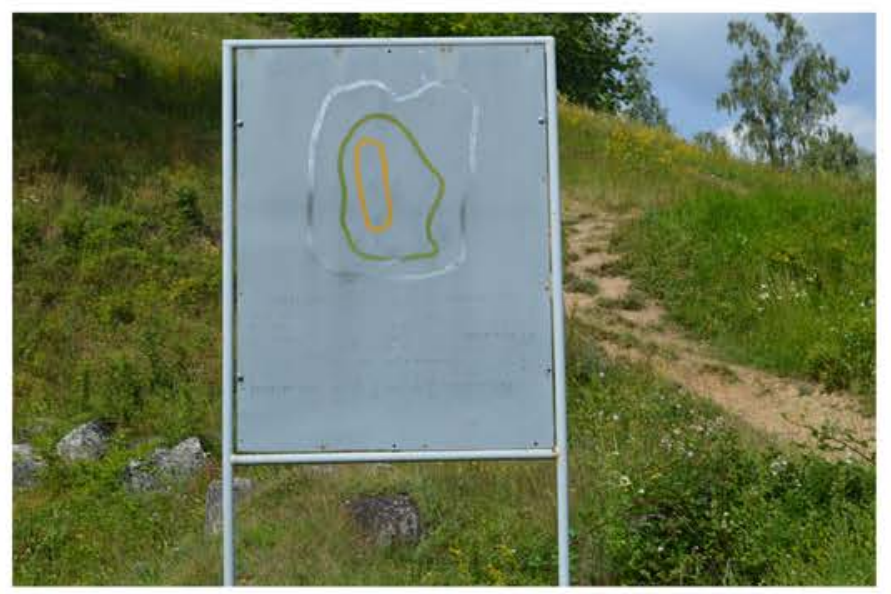

3

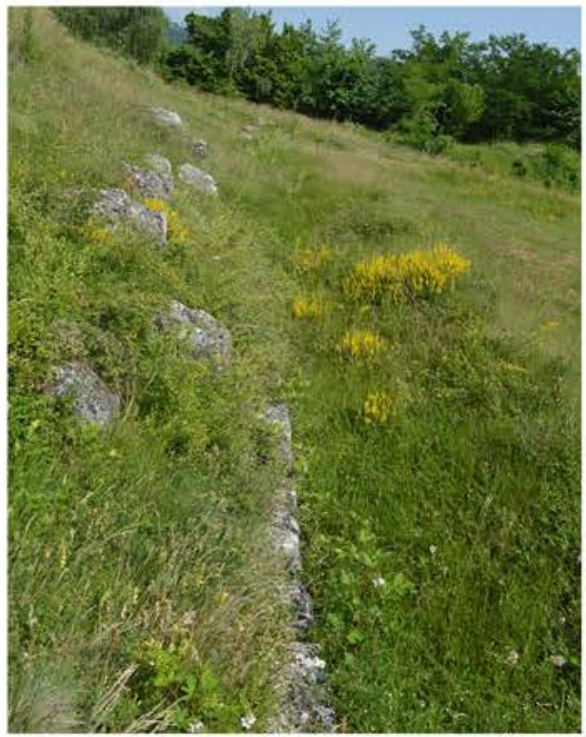

5

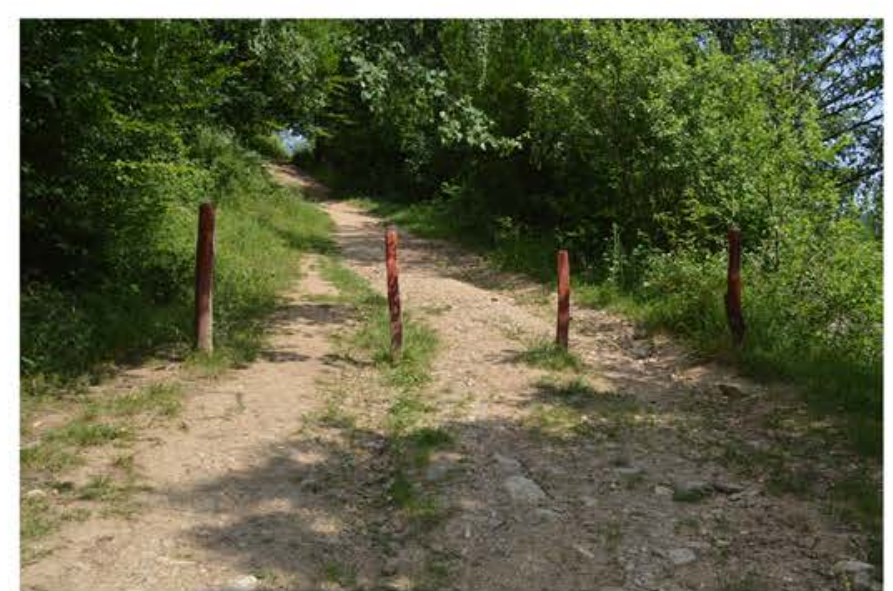

2

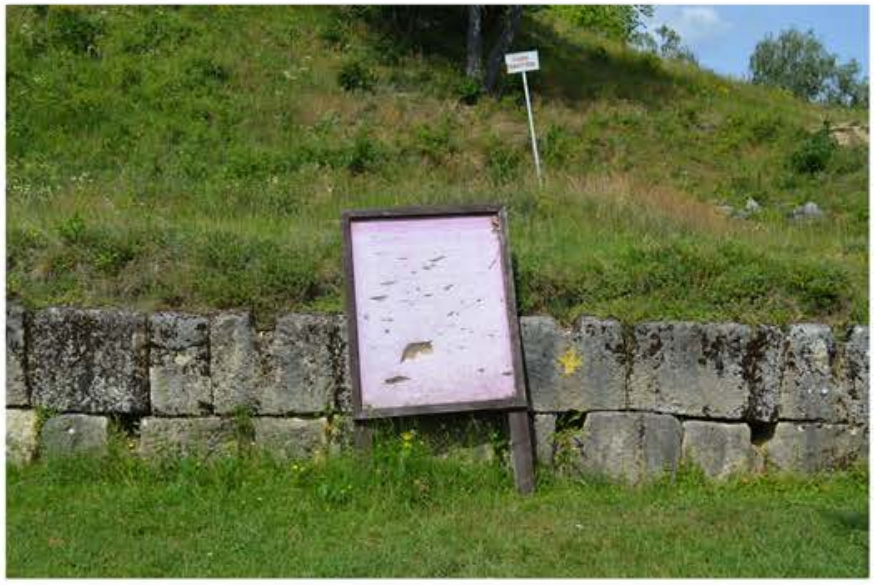

4

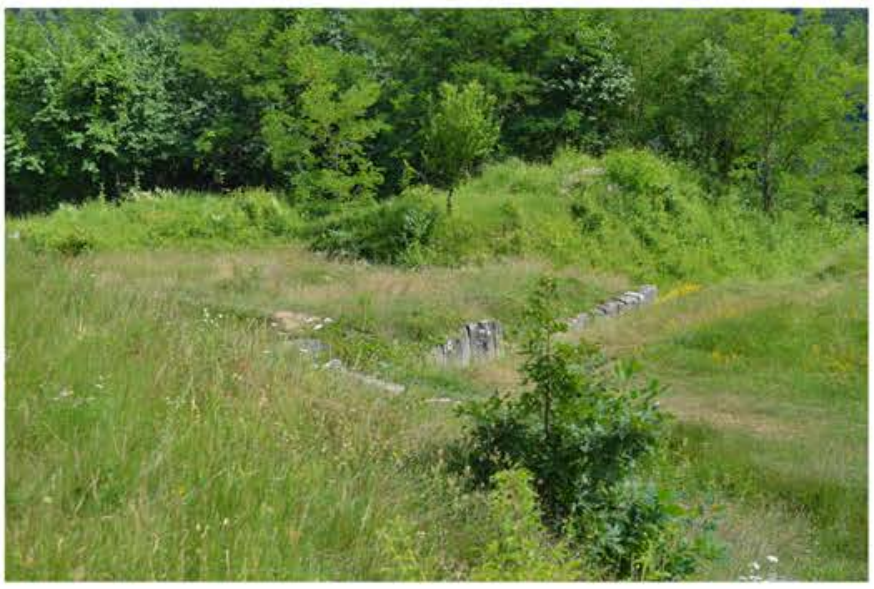

6

Pl. 12. Signalling panels (1), access road (2), explanatory panels (3-4) and wall parts of the fortress at Costești-Cetățuie (photo Vitalie Bârcă, 2018). 


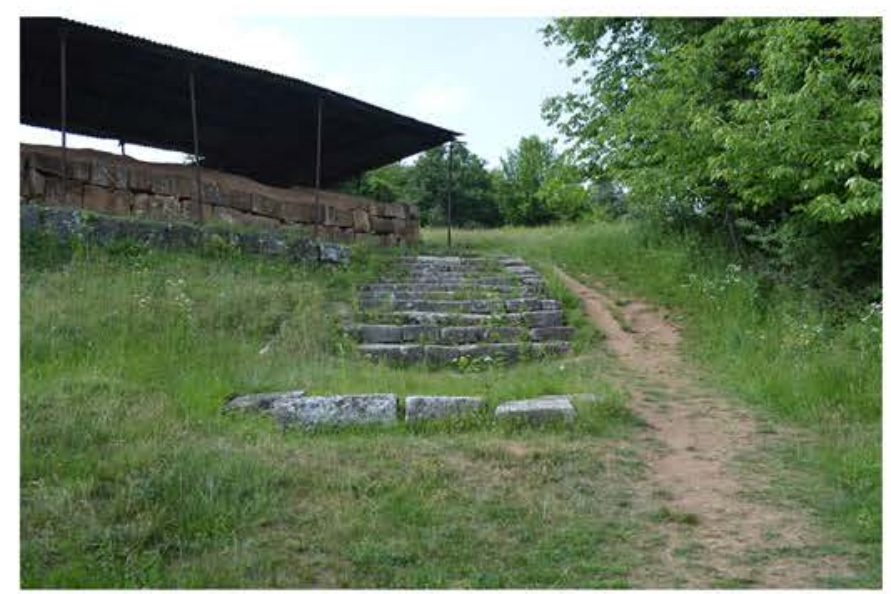

1

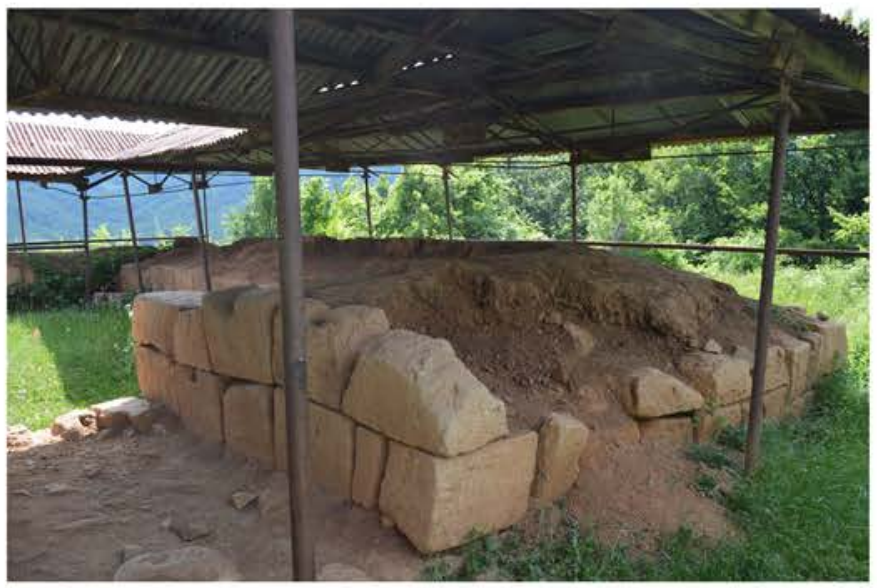

3

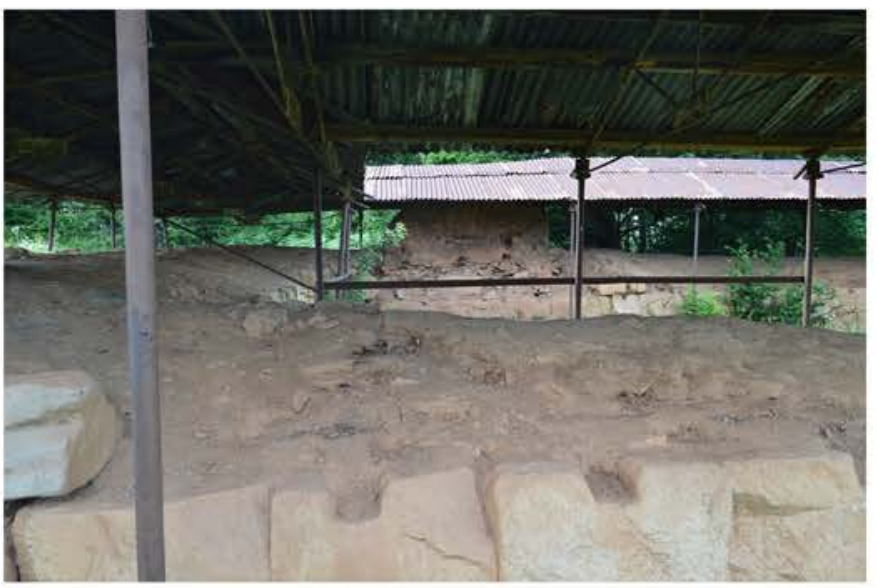

5

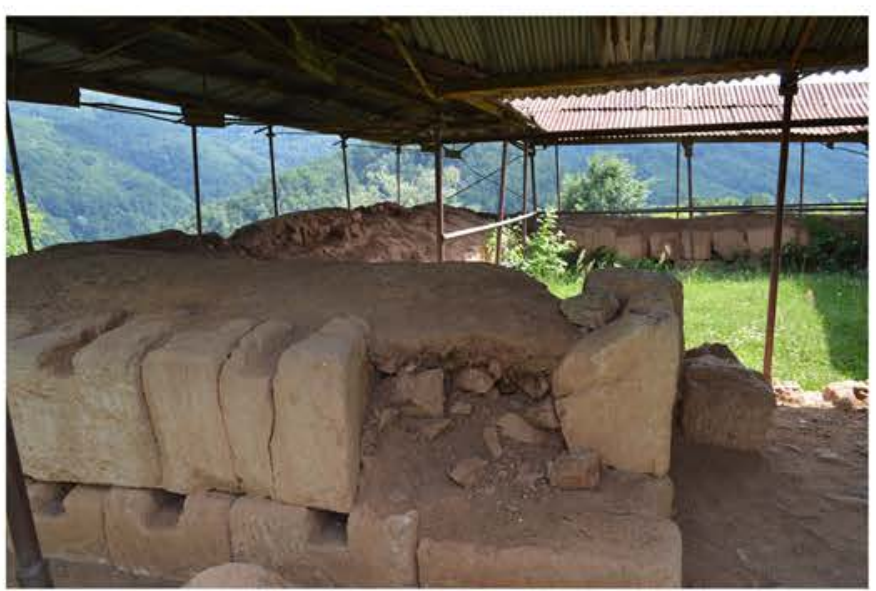

2

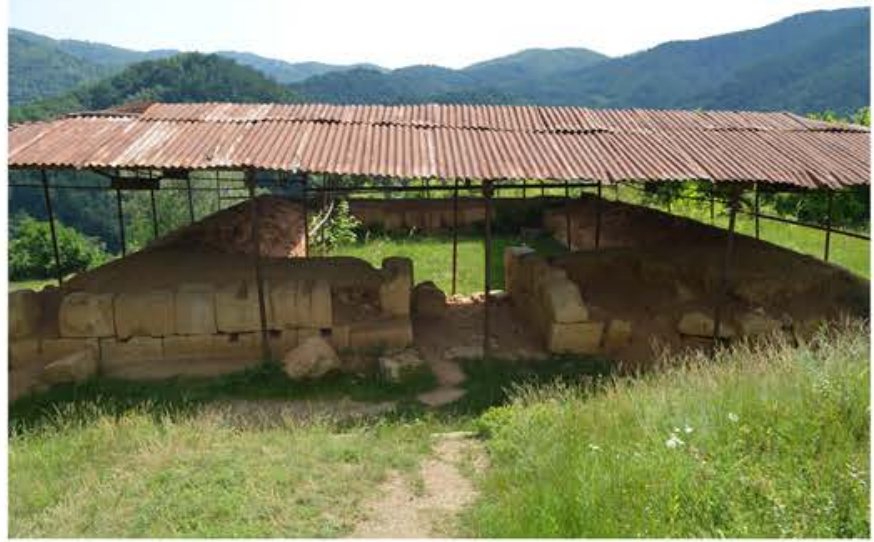

4

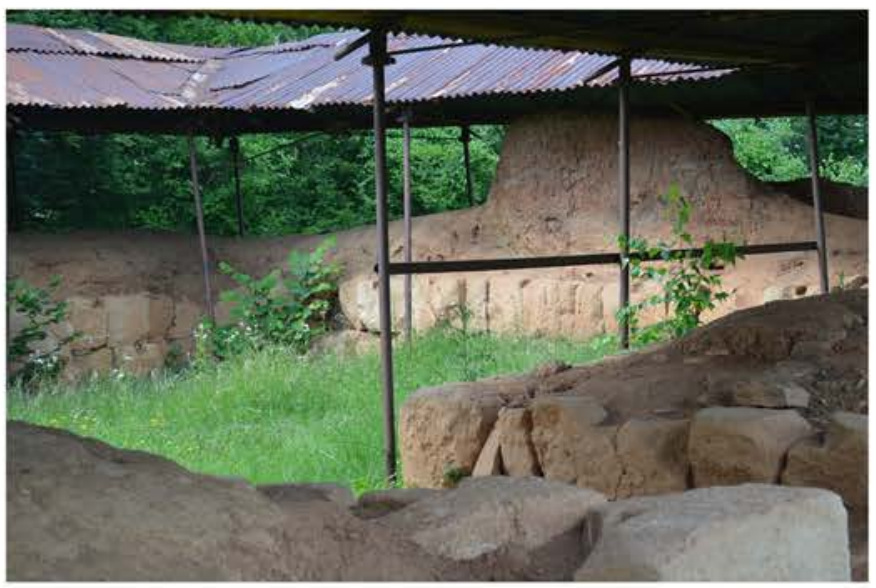

6

PI. 13. Monumental stairs with massive stone stairs (1) and tower-houses from the fortress at Costești-Cetățuie (2-6) (photo Vitalie Bârcă, 2018). 
Studies

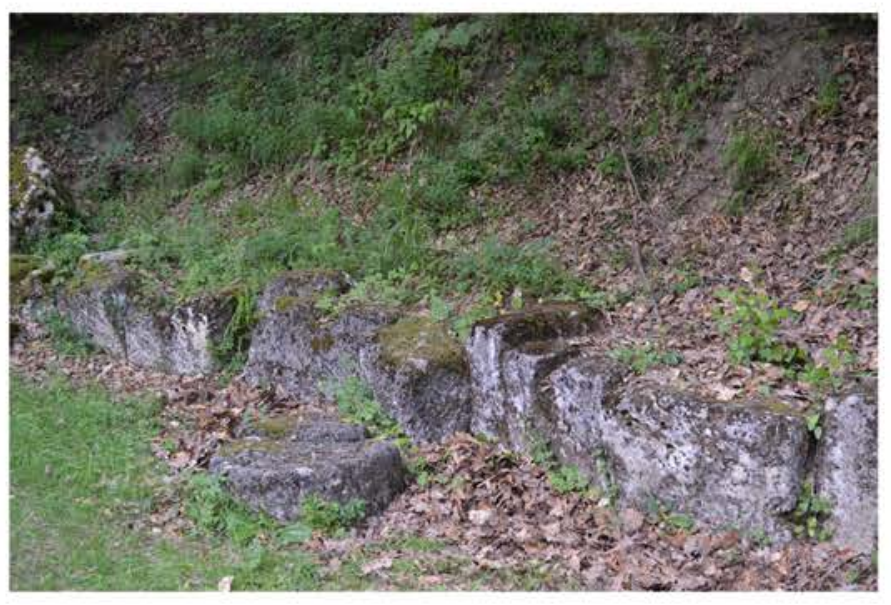

1

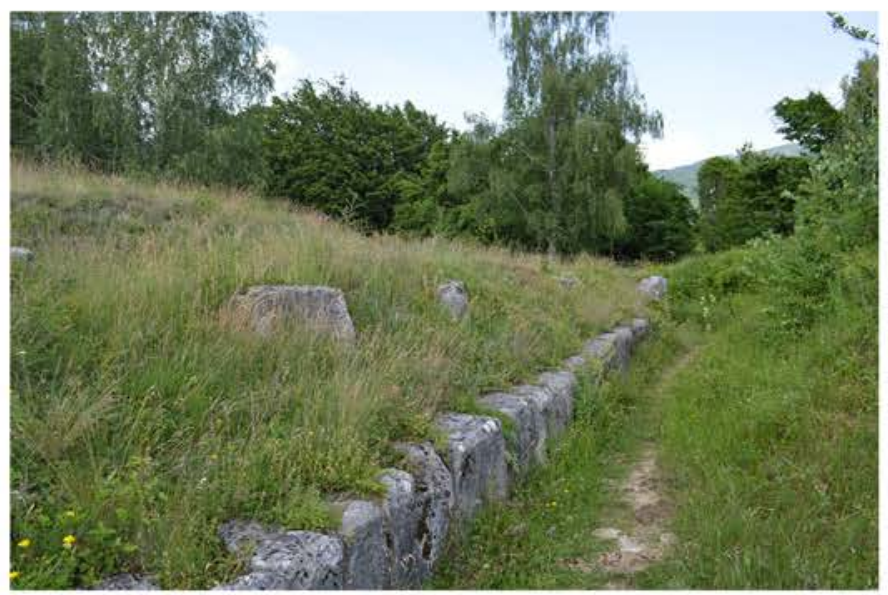

3

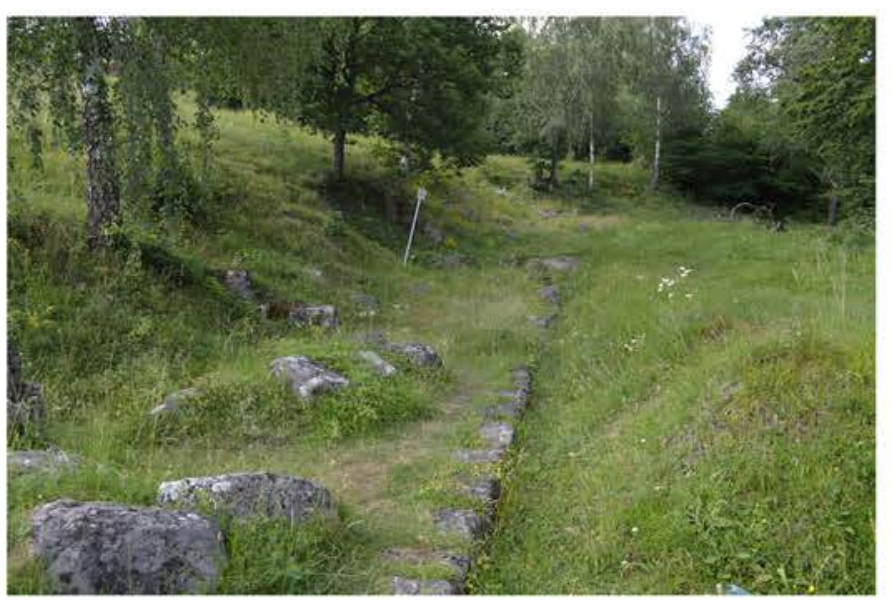

5

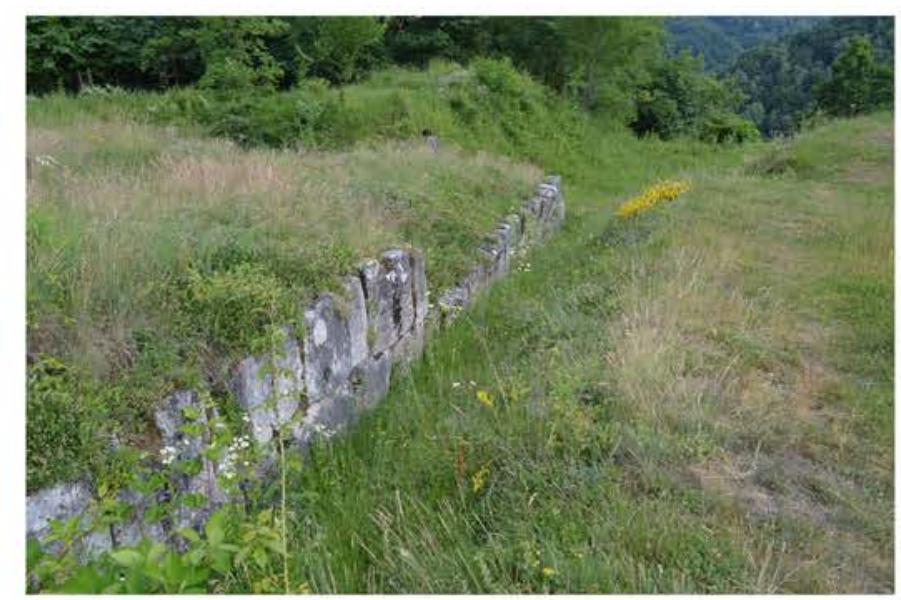

2

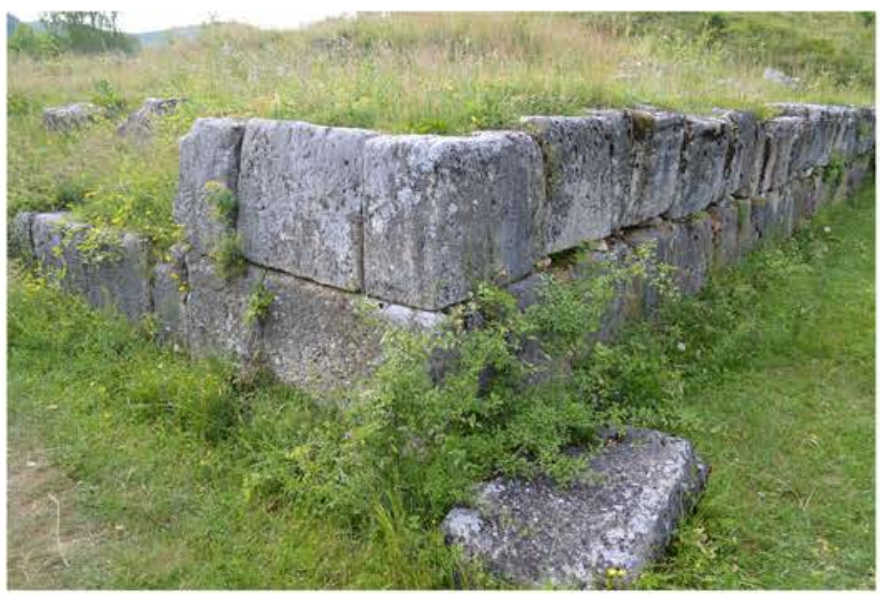

4

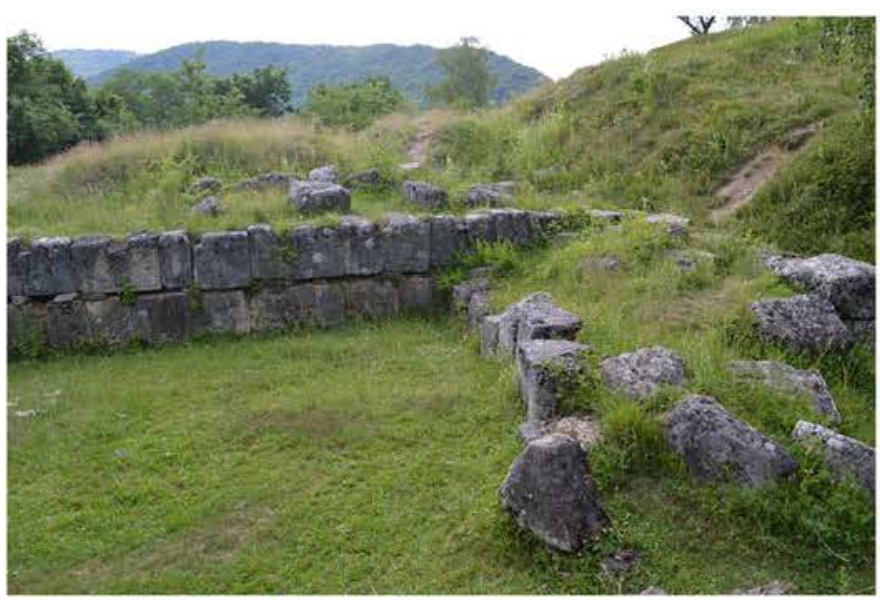

6

Pl. 14. Images with the walls and bastions from Costești-Cetățuie (photo Vitalie Bârcă, 2018). 


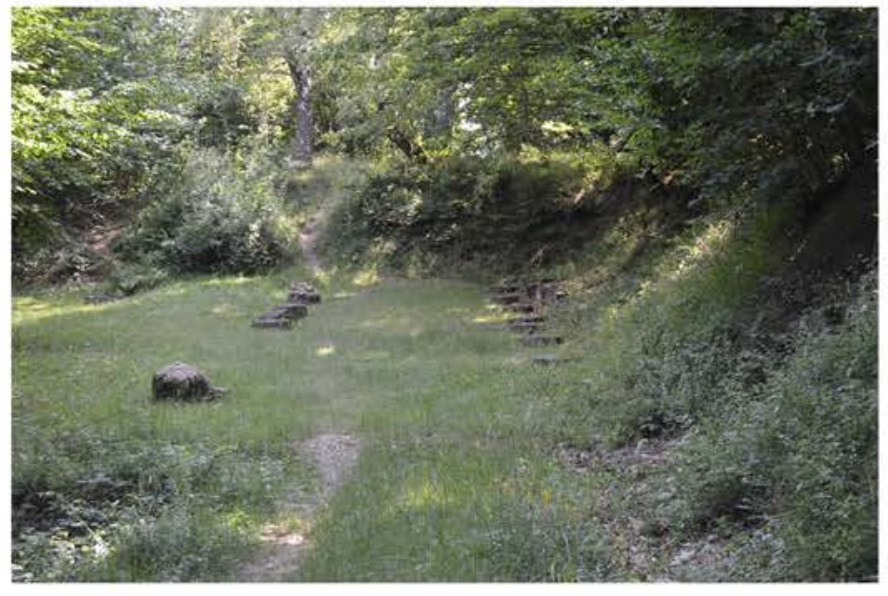

1

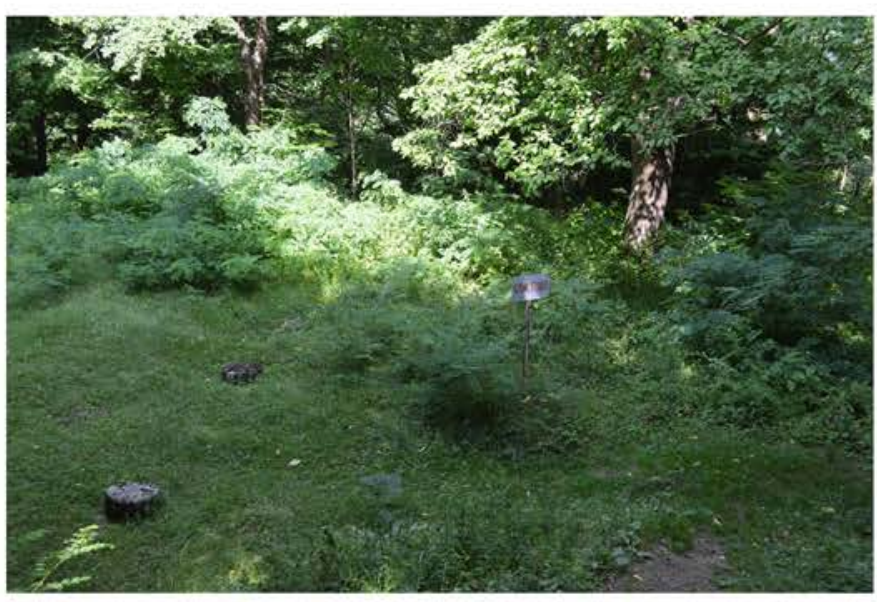

3

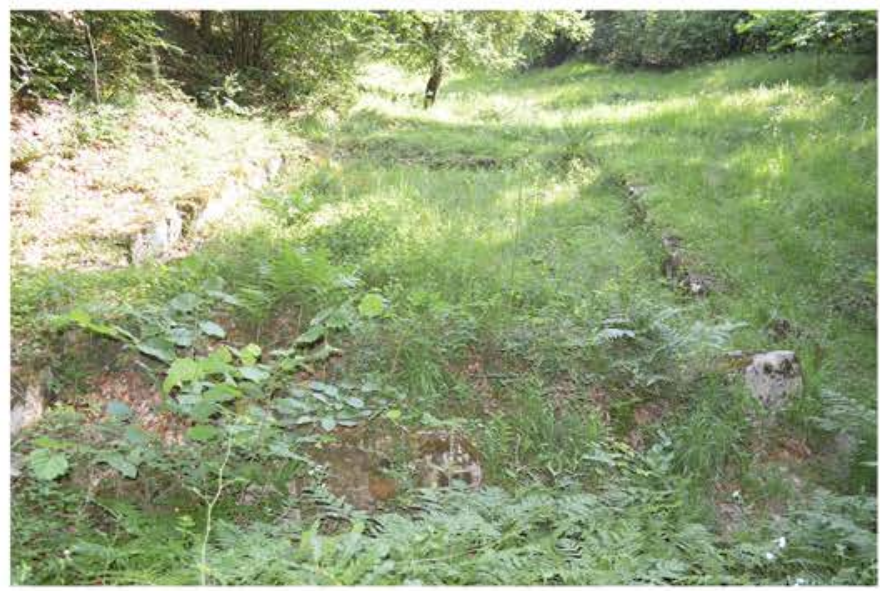

5

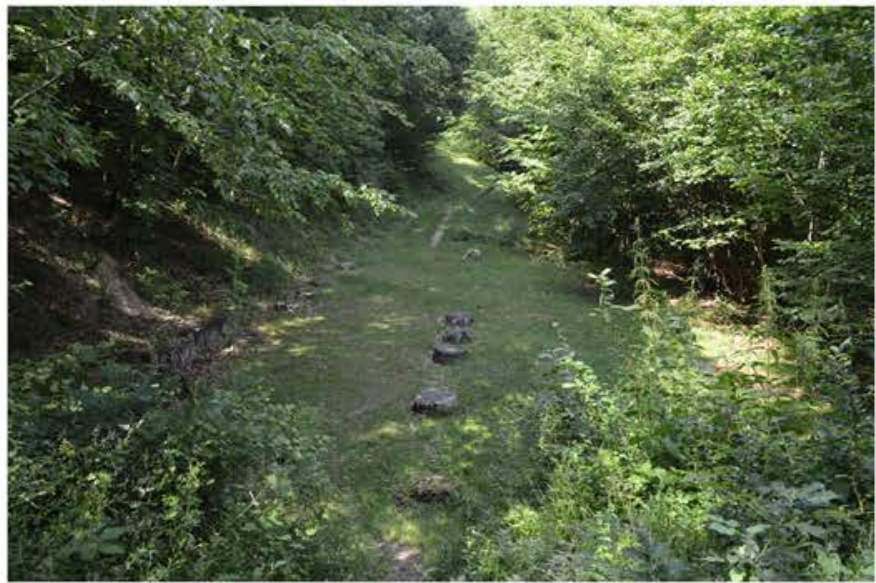

2

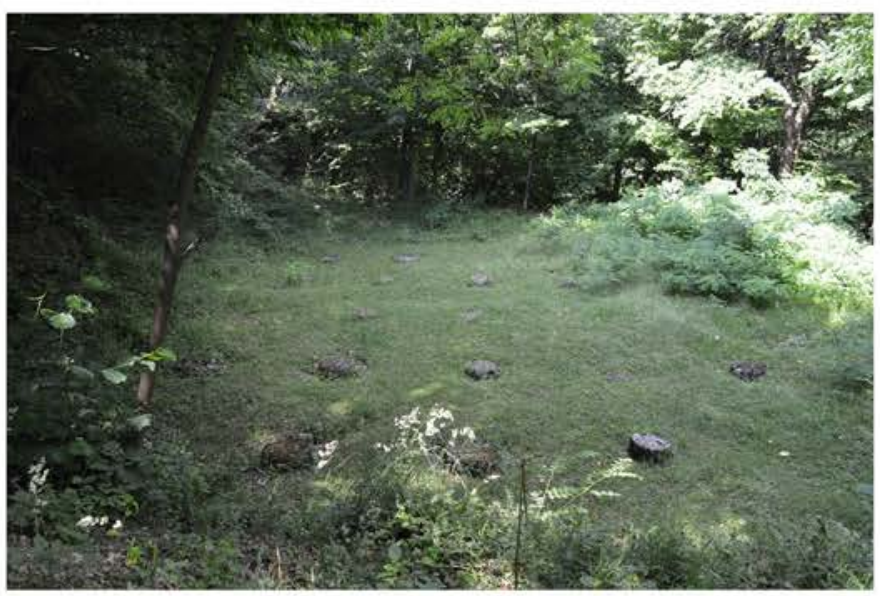

4

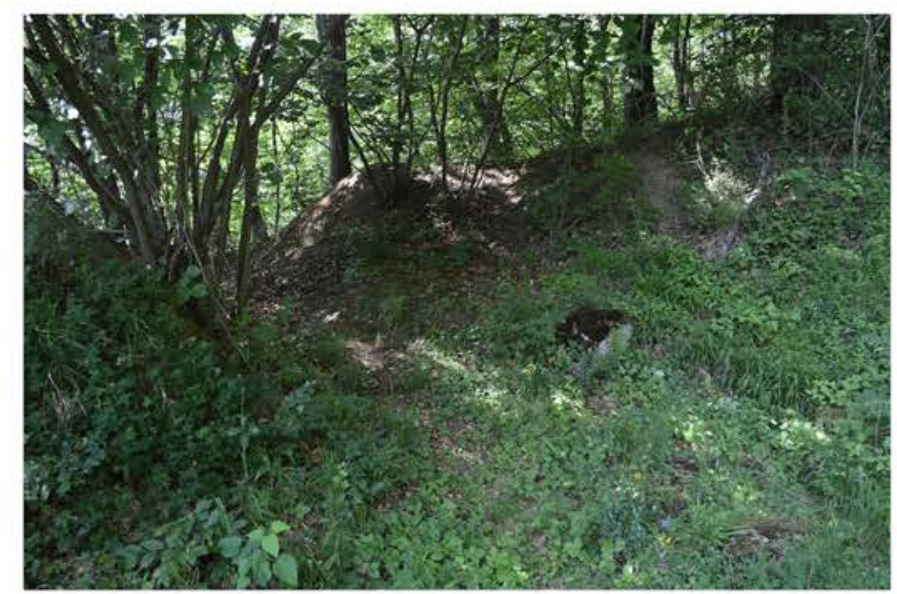

6

Pl. 15. Images of the sanctuaries (1-4), bastion (5) and part of the earth embankment (6) on the western side of Costești-Cetățuie (photo Vitalie Bârcă, 2018). 


\section{Studies}

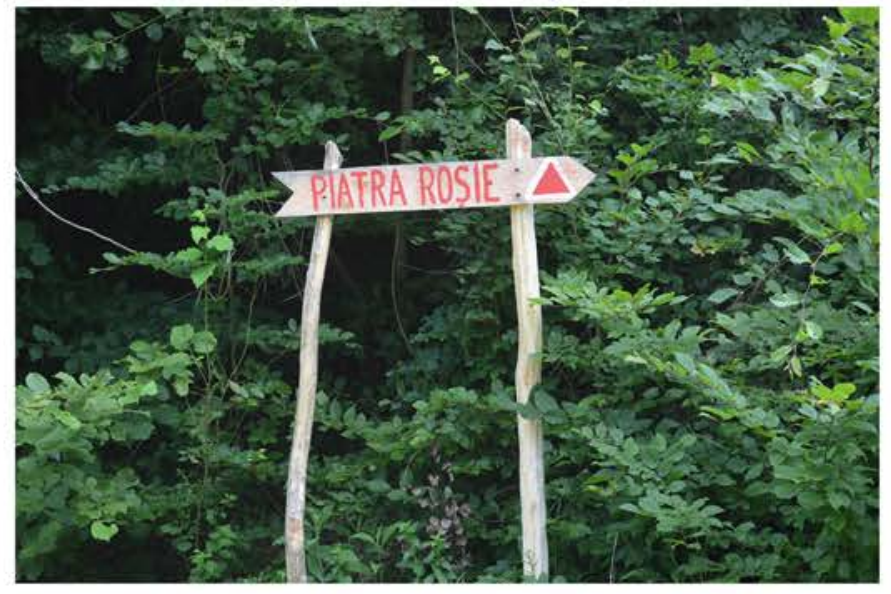

1

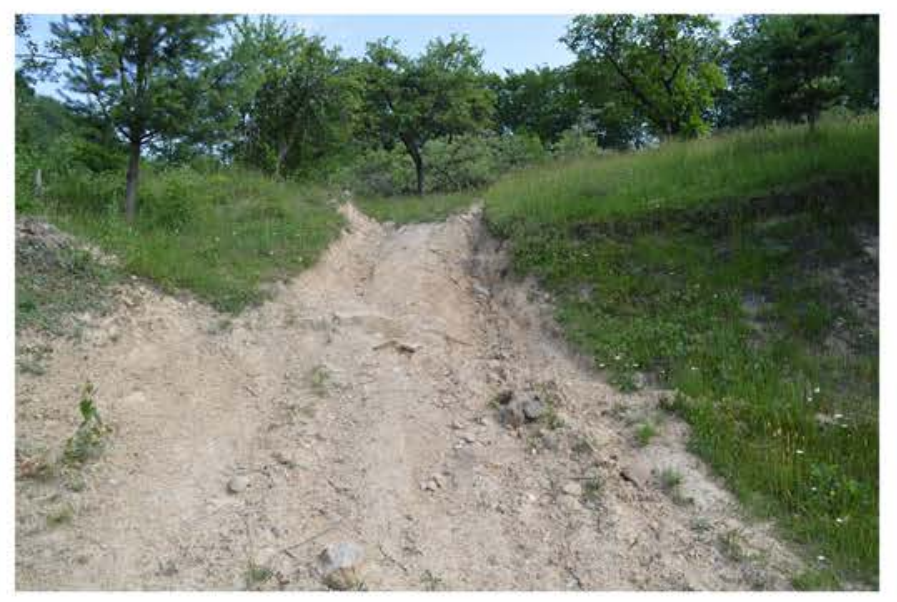

3

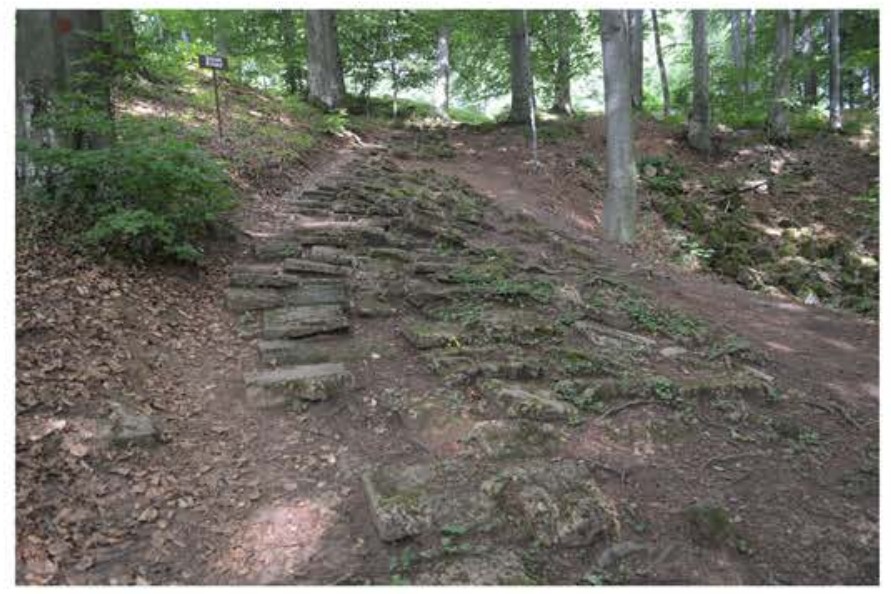

5

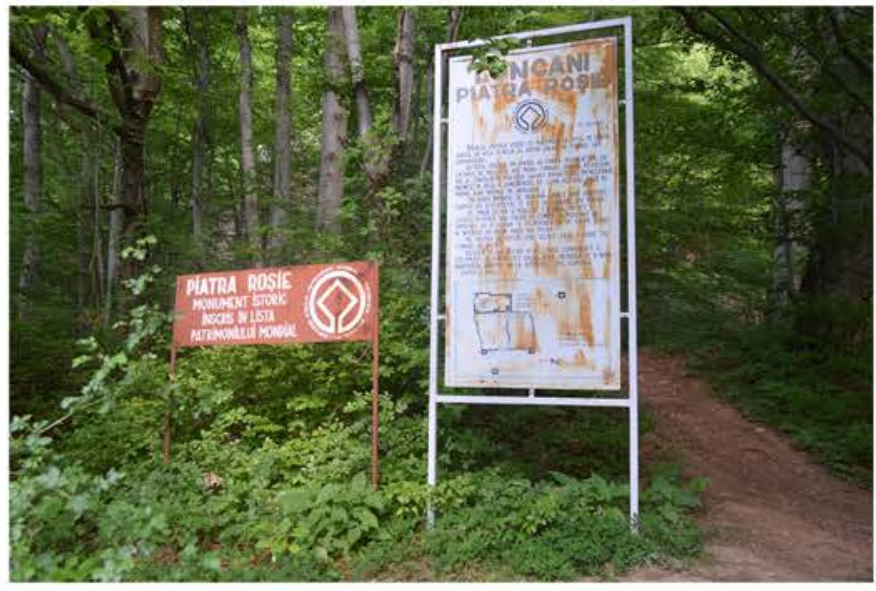

2

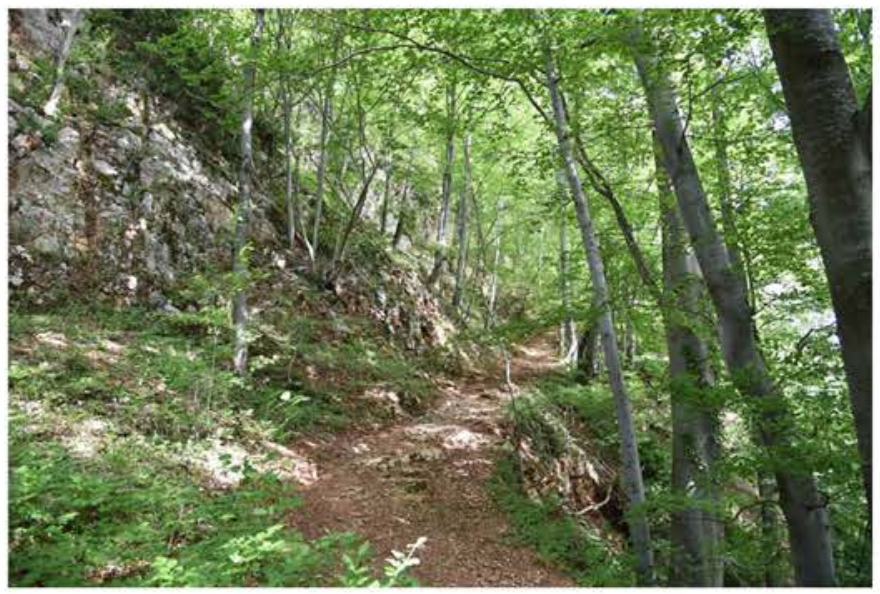

4

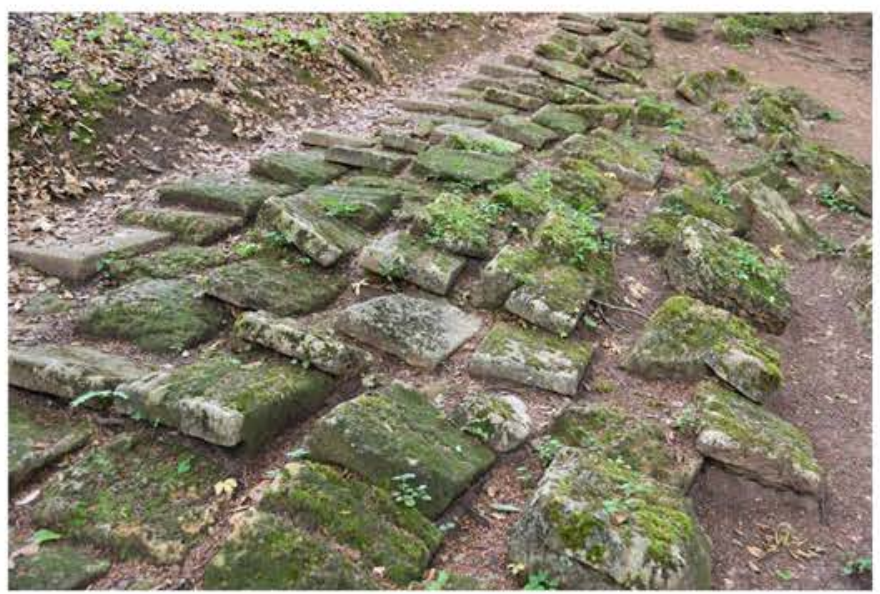

6

Pl. 16. Signalling and explanatorypanels (1-2), parts of the access road to the fortress (3-4), access stairs and paved road (5-6) from Piatra Roșie (photo Vitalie Bârcă, 2018). 

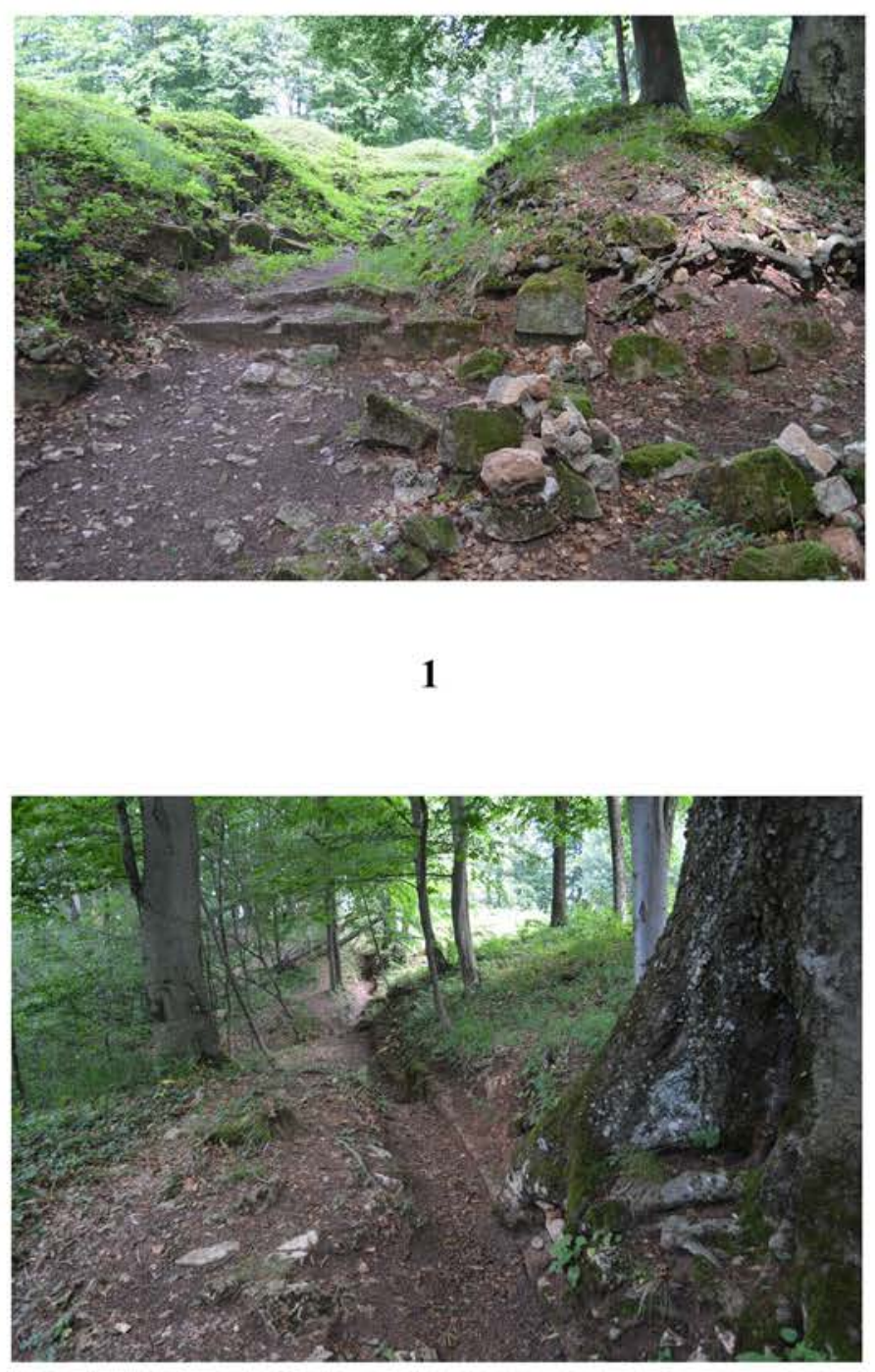

3

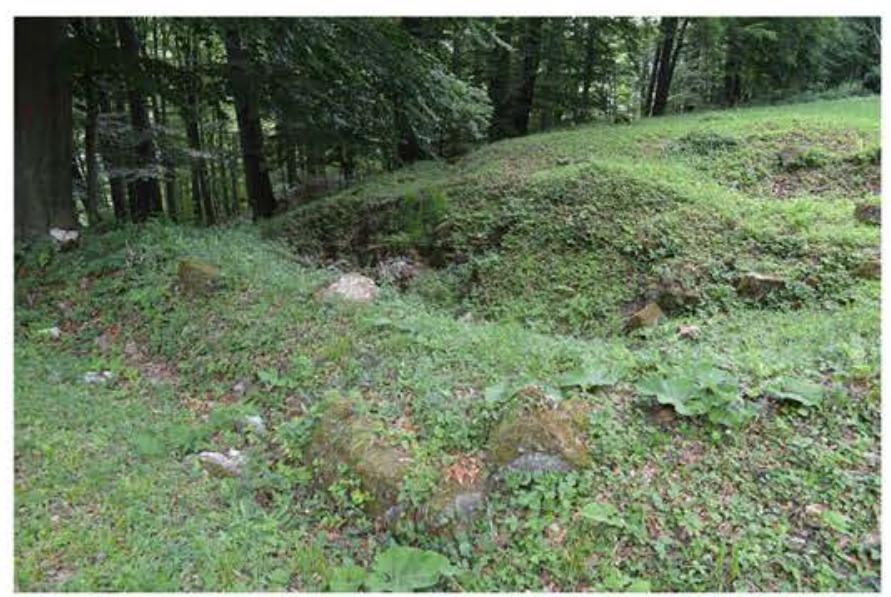

5

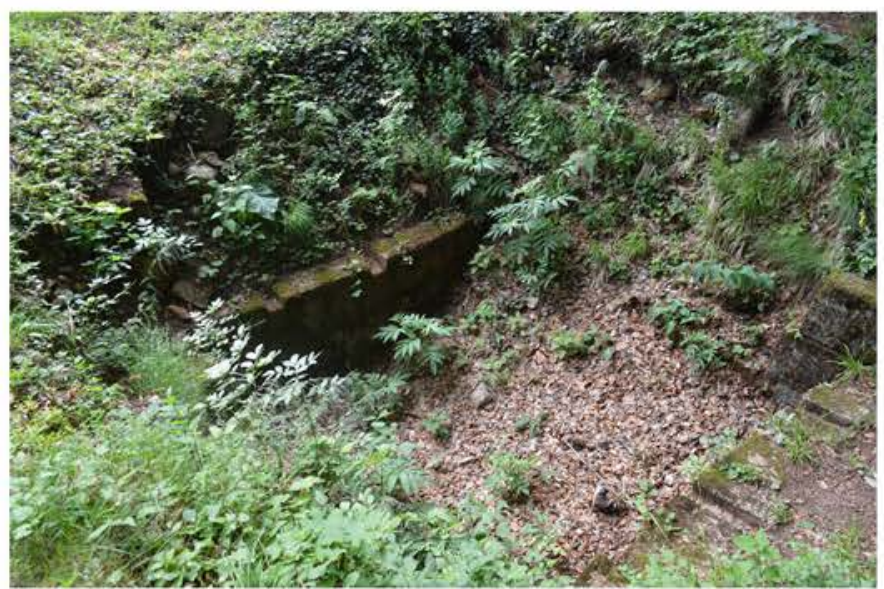

2

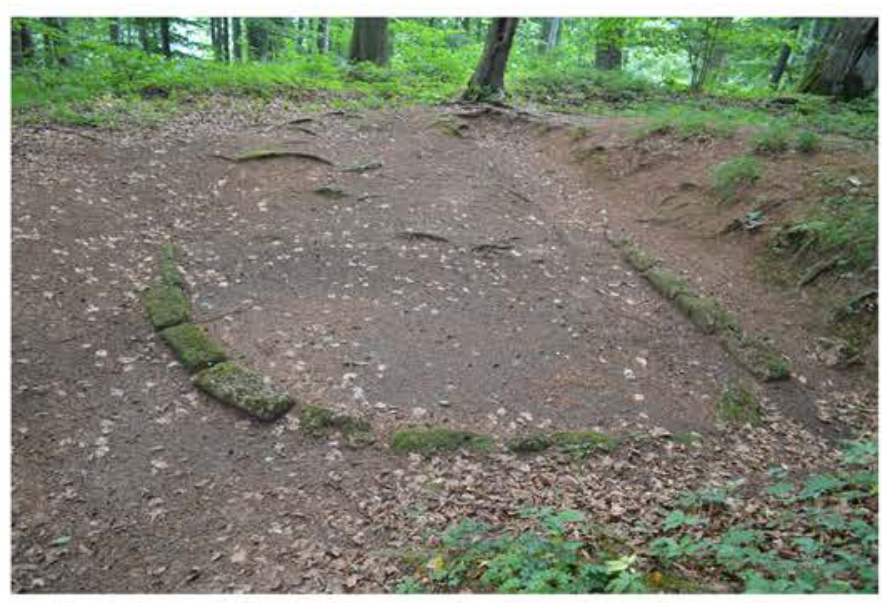

4

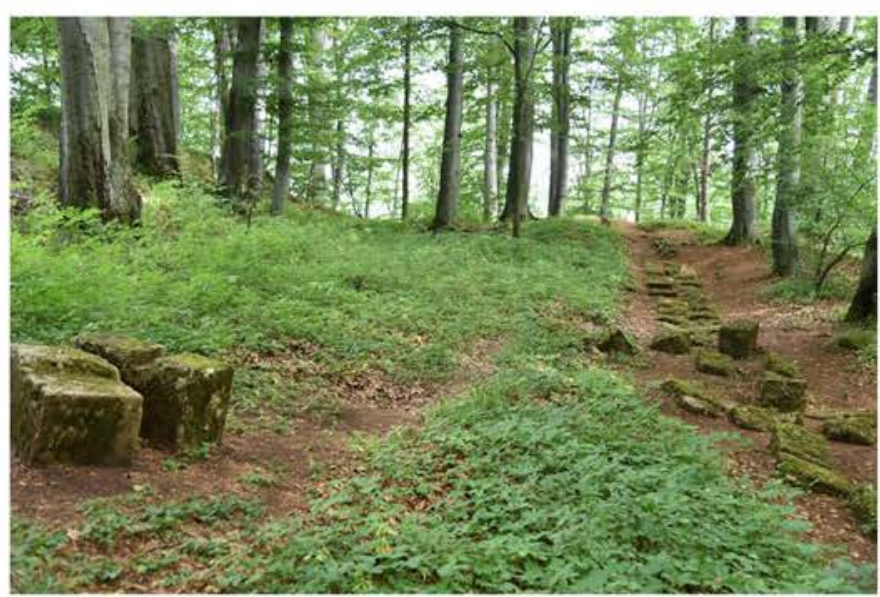

6

Pl. 17. Images with the entrance in the enclosure on the fortress plateau (1), walls, bastions and buildings from Piatra Roșie (photo Vitalie Bârcă, 2018). 


\section{Studies}

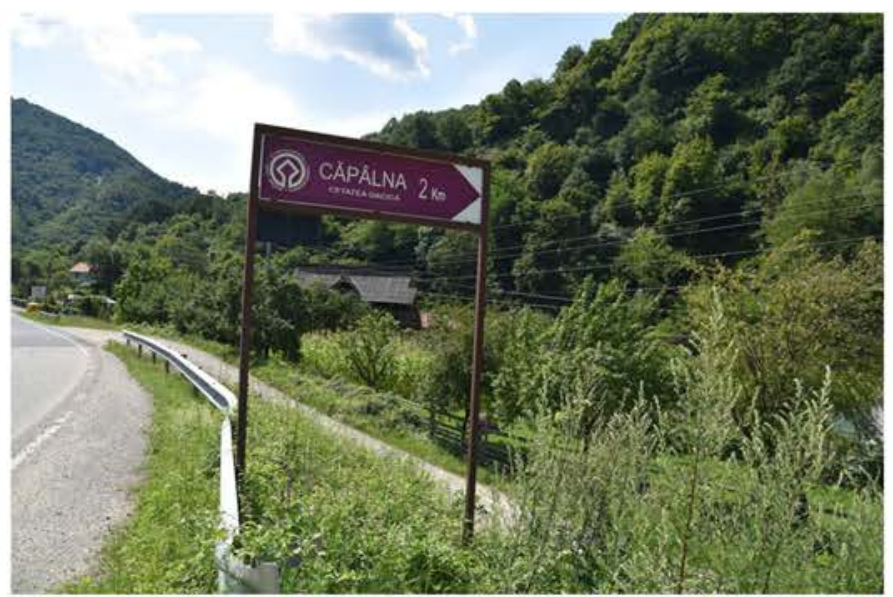

1

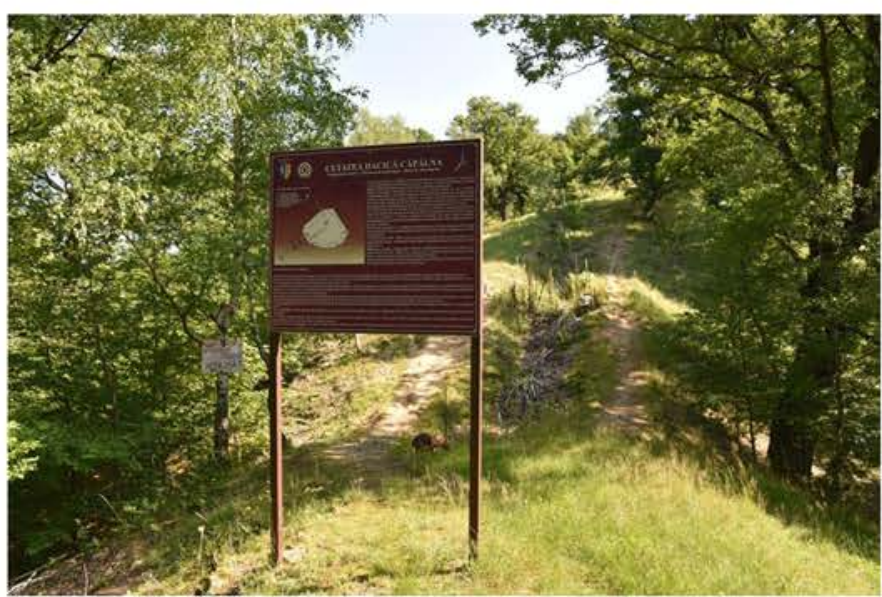

3

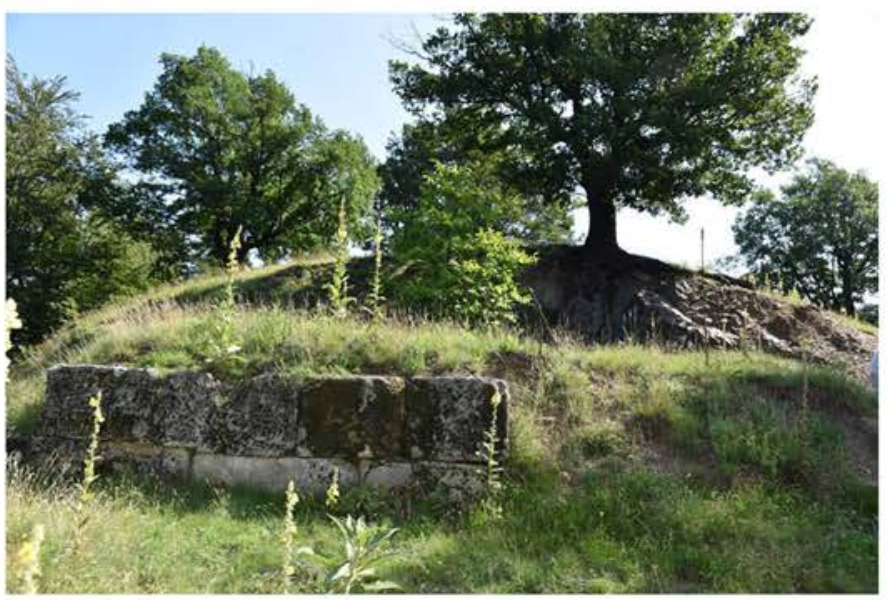

5

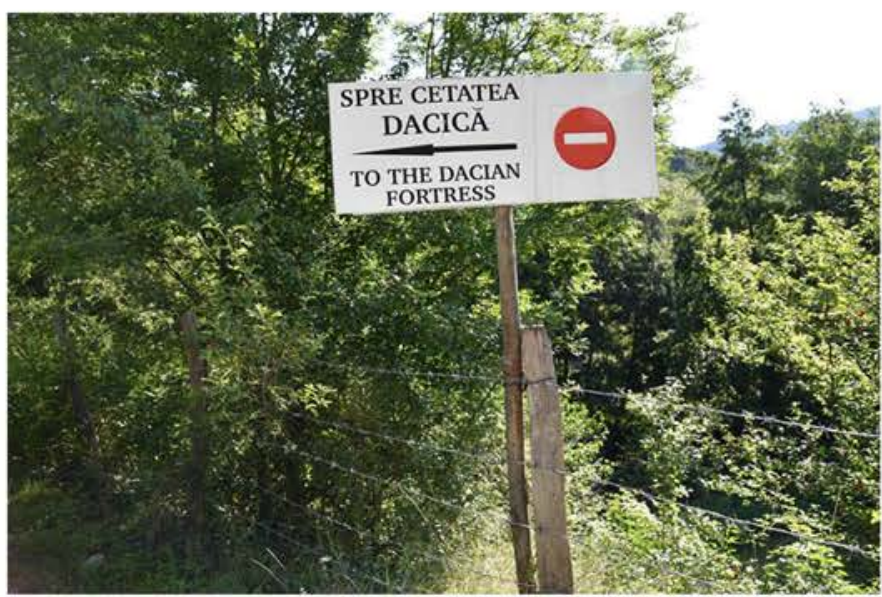

2

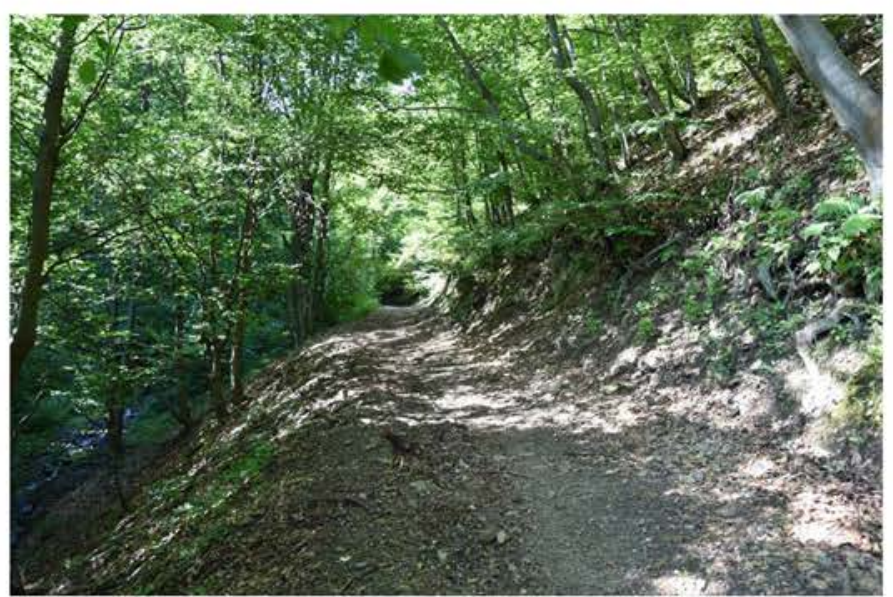

4

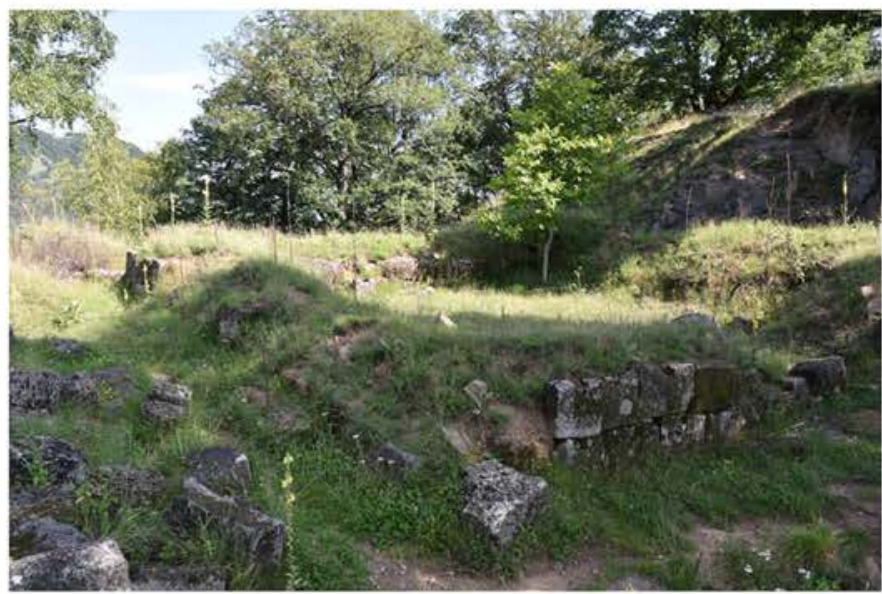

6

Pl. 18. Signalling (1-2) and explanatory (3) panels, parts of the access road (4) and images of the tower (5-6) from the fortress at Căpâlna (photo Sergiu Musteață). 


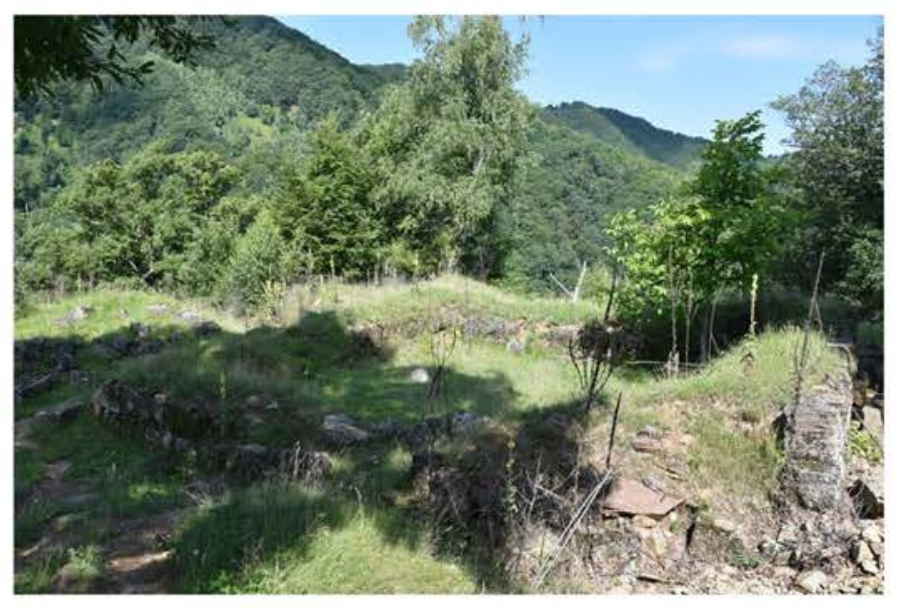

1

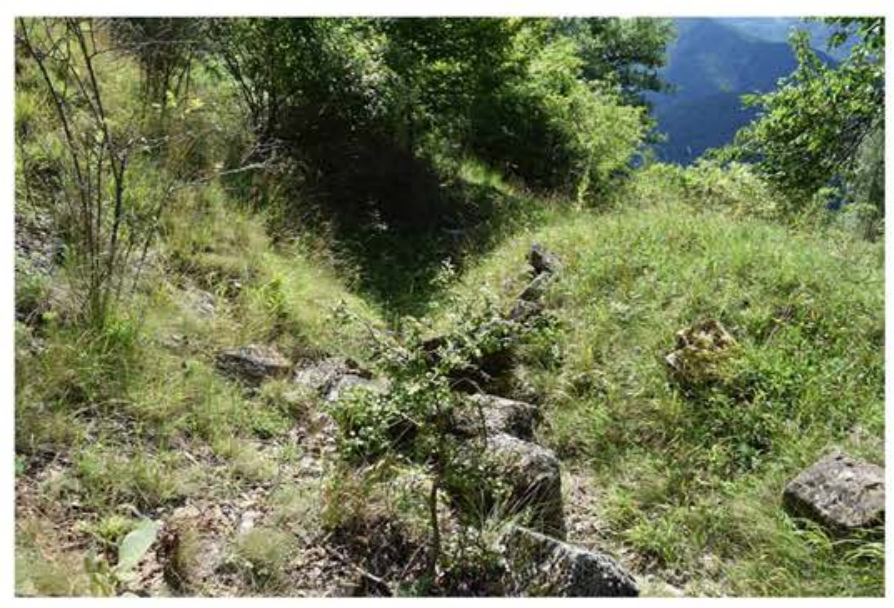

3

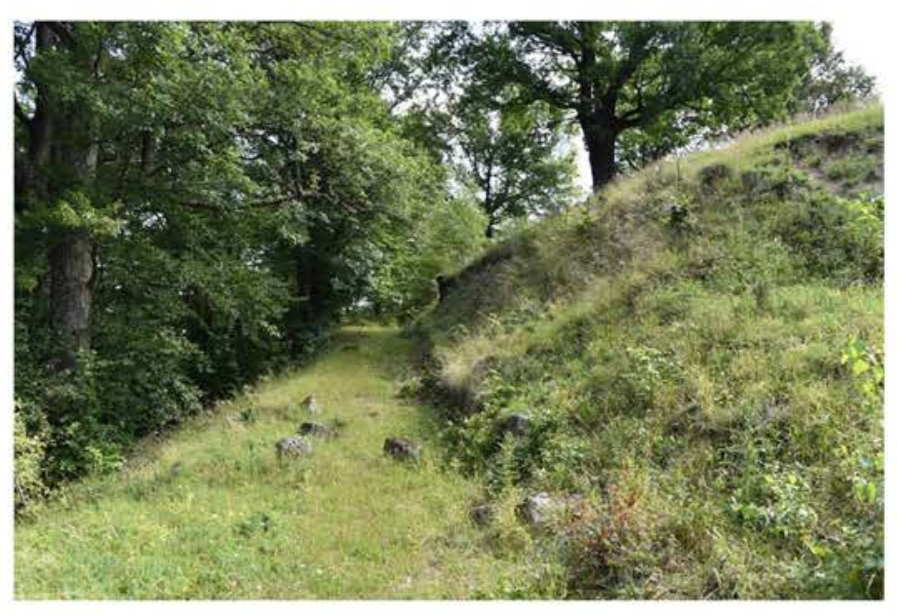

5

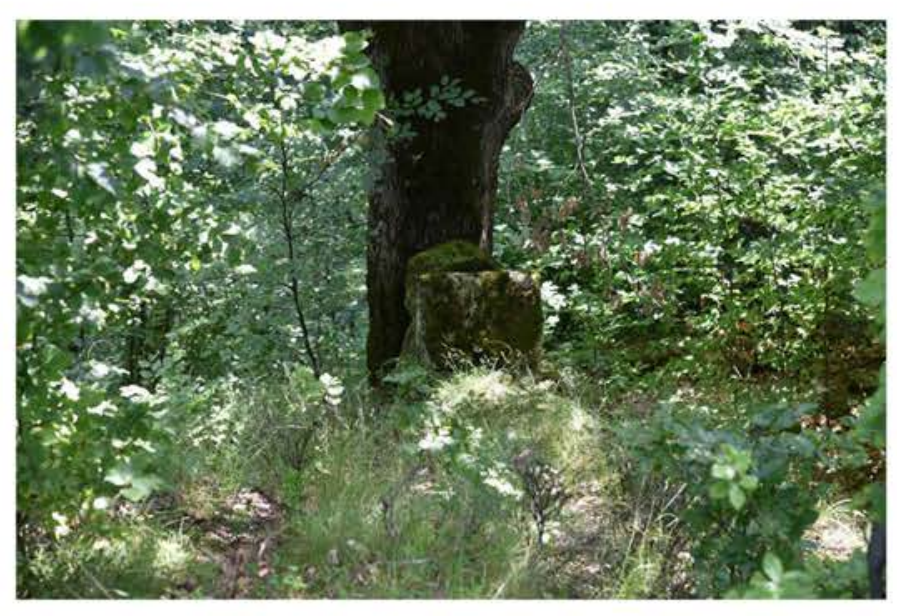

2

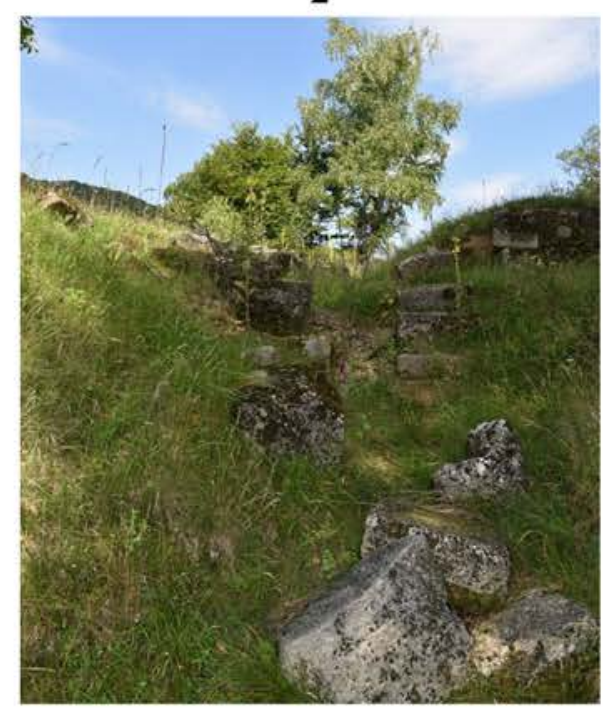

4

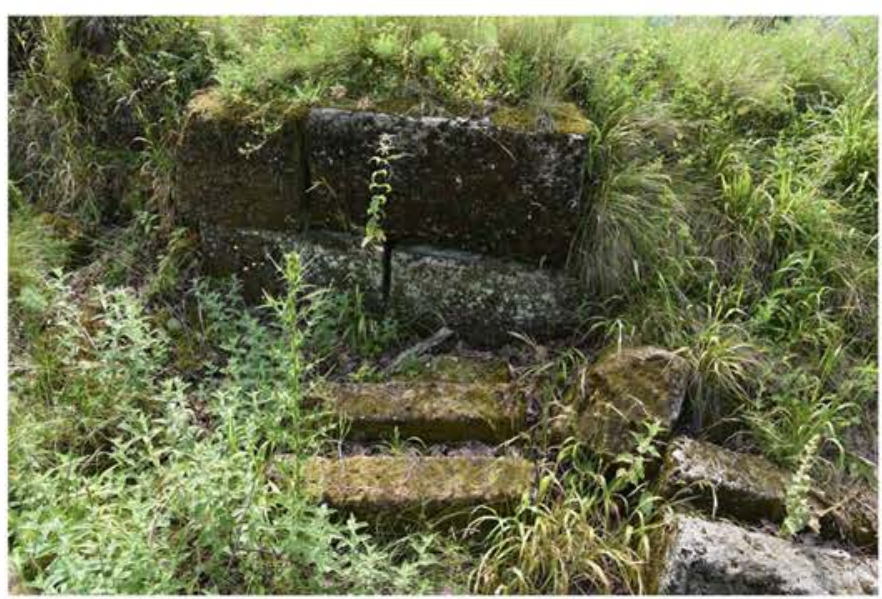

6

PI. 19. Images from the fortress at Căpâlna (photo Sergiu Musteață). 


\section{Studies}
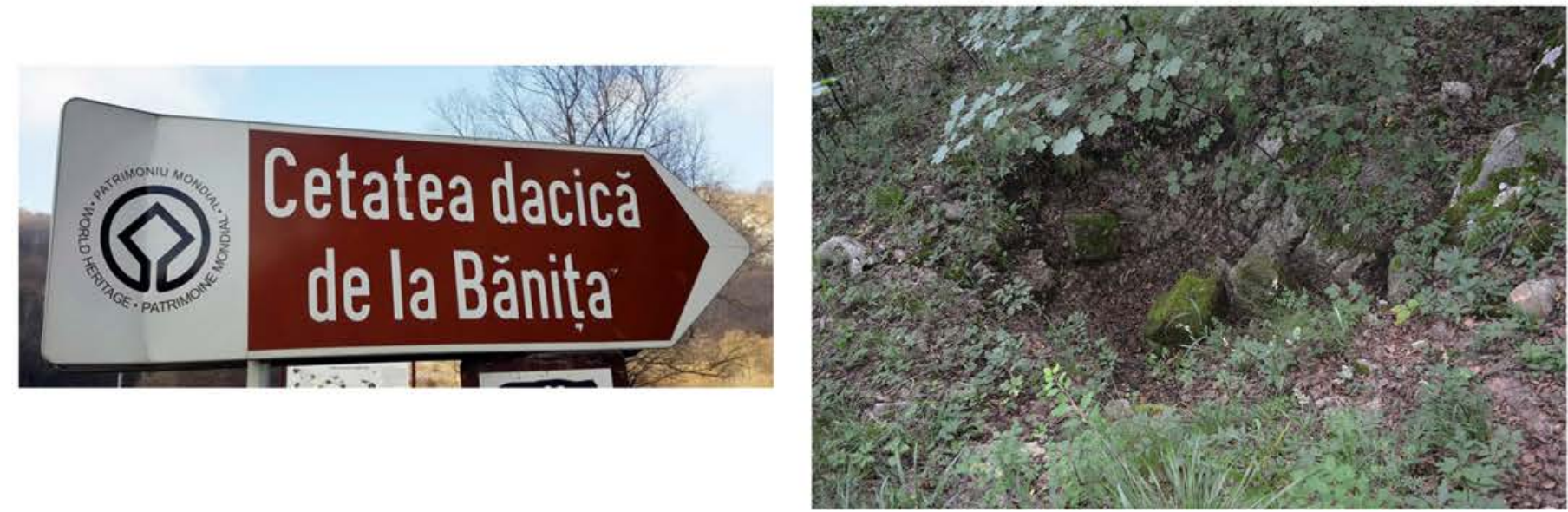

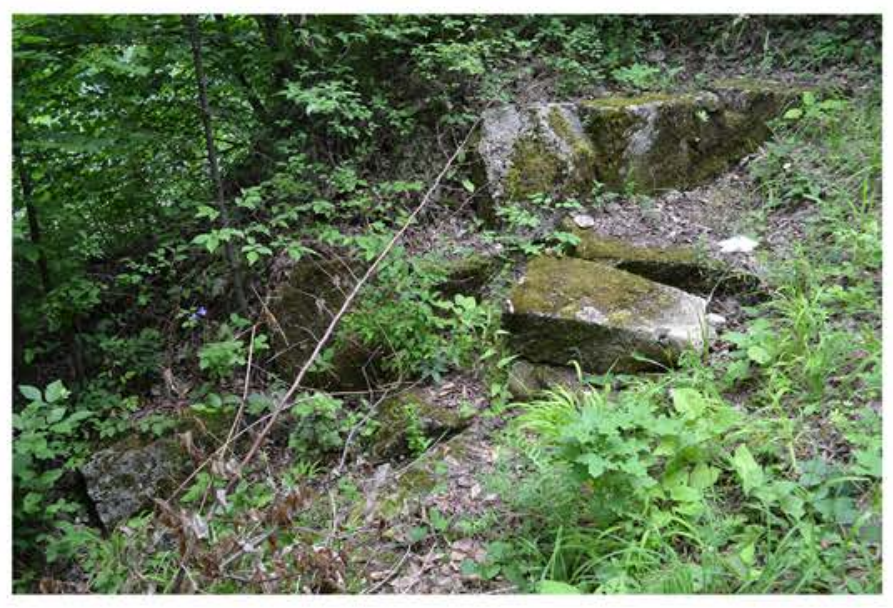

3

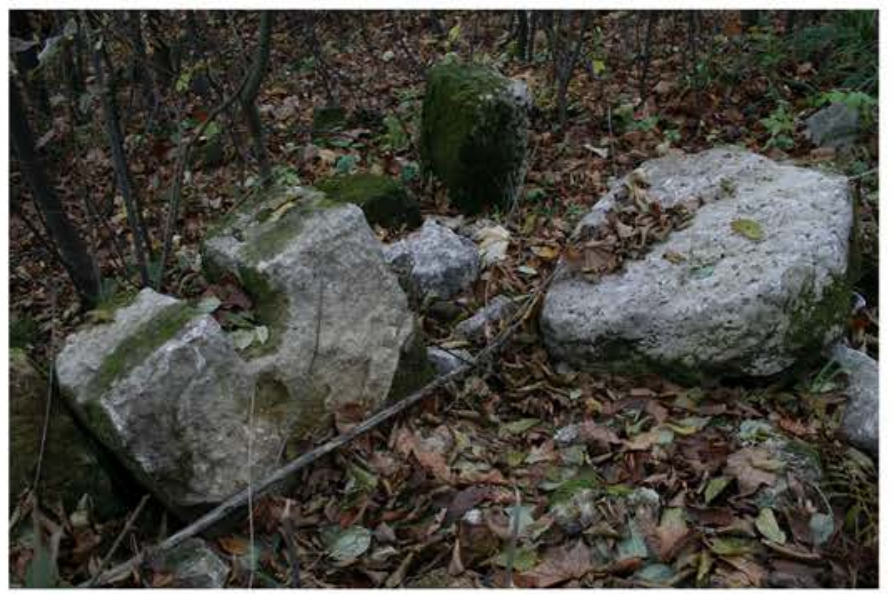

5

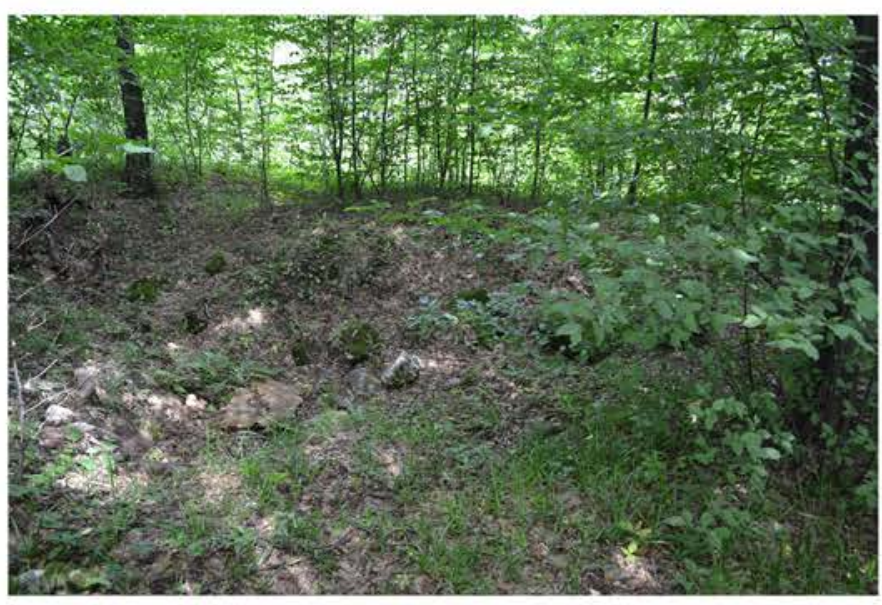

4

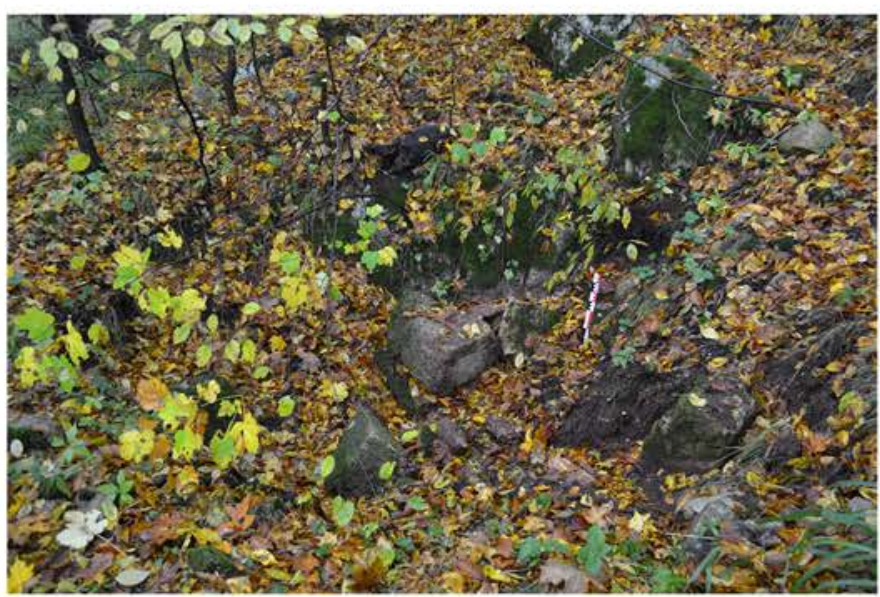

6

Pl. 20. Images from the fortress at Bănița (photo Cătălin Cristescu). 


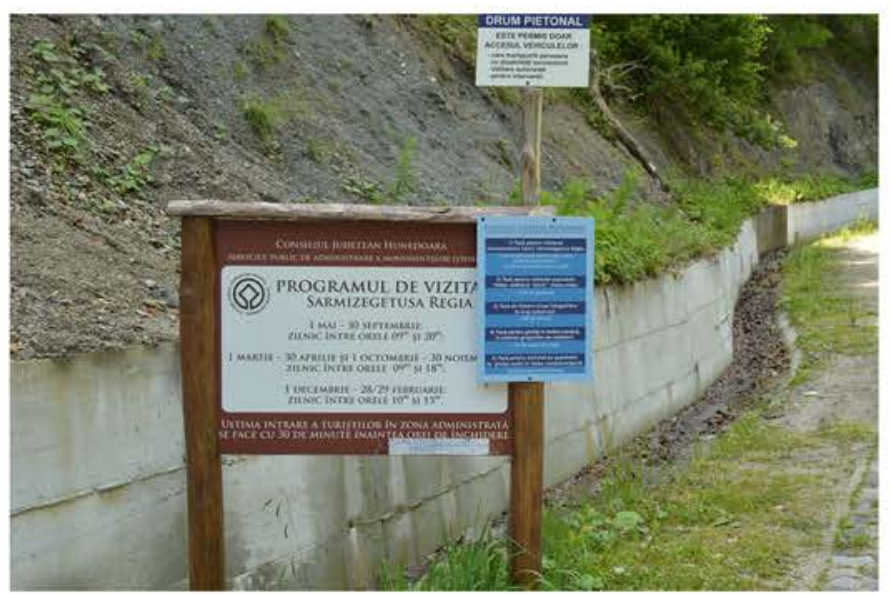

1

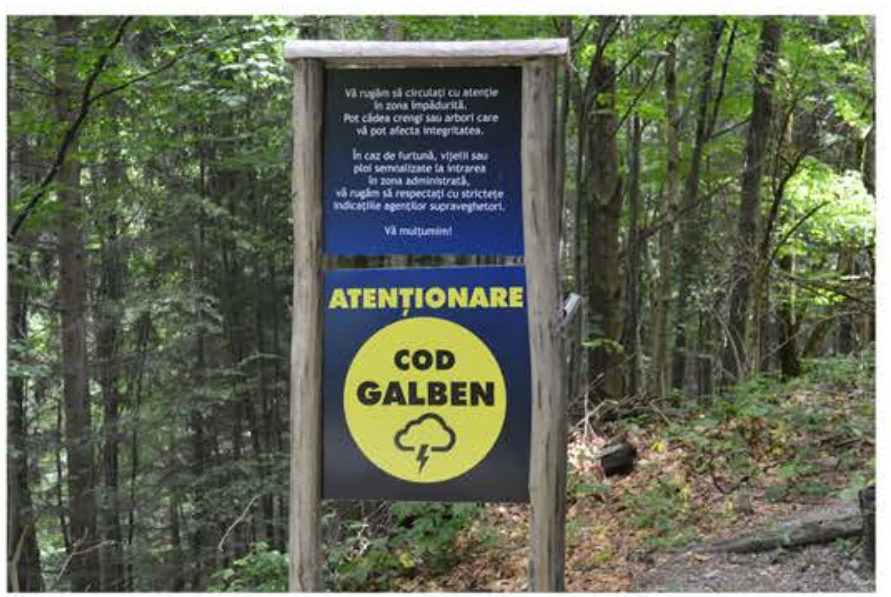

3

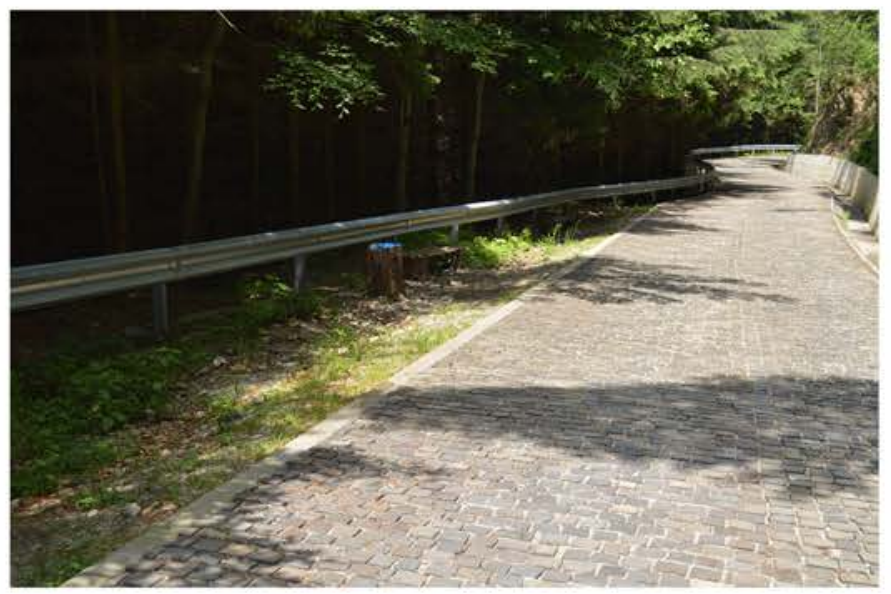

5

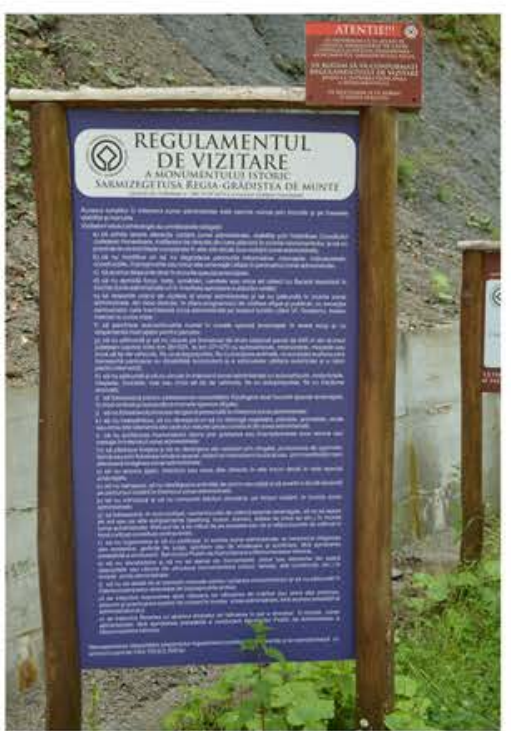

2

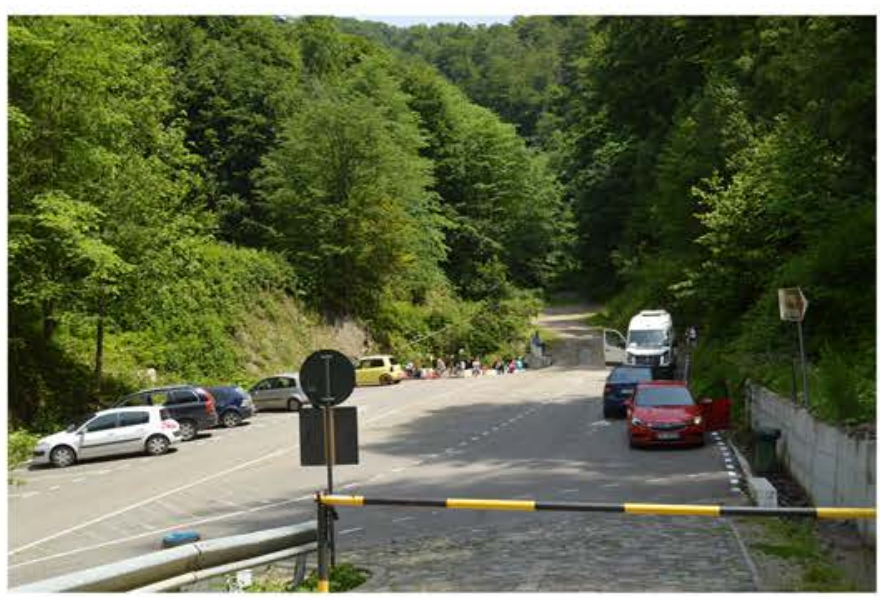

4

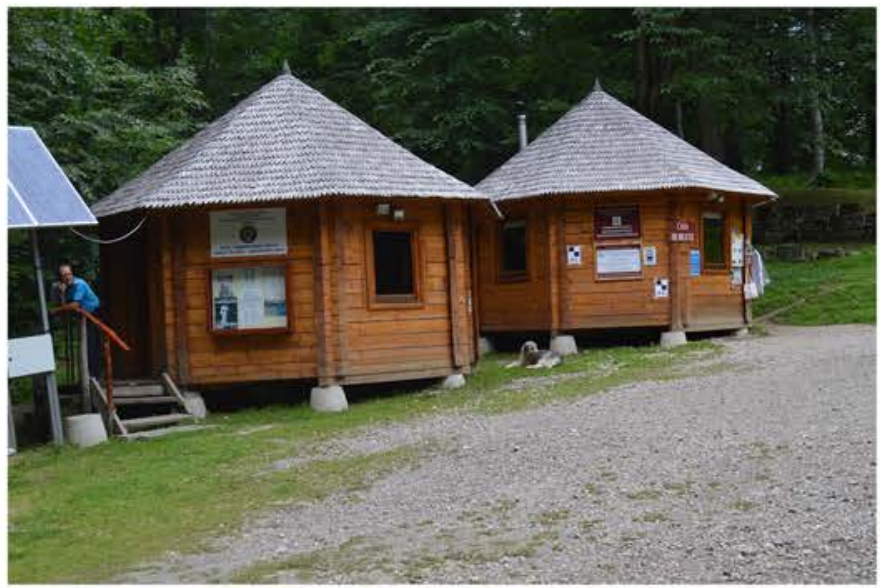

6

Pl. 21. Sarmizegetusa Regia. Explanatory (1-2) and warning panels (3), parking set up at ca. $1 \mathrm{~km}$ from site (4), access road (5), mobile wooden pavilions for Management and Gendarmerie (6) (photo Vitalie Bârcă, 2018). 
Studies
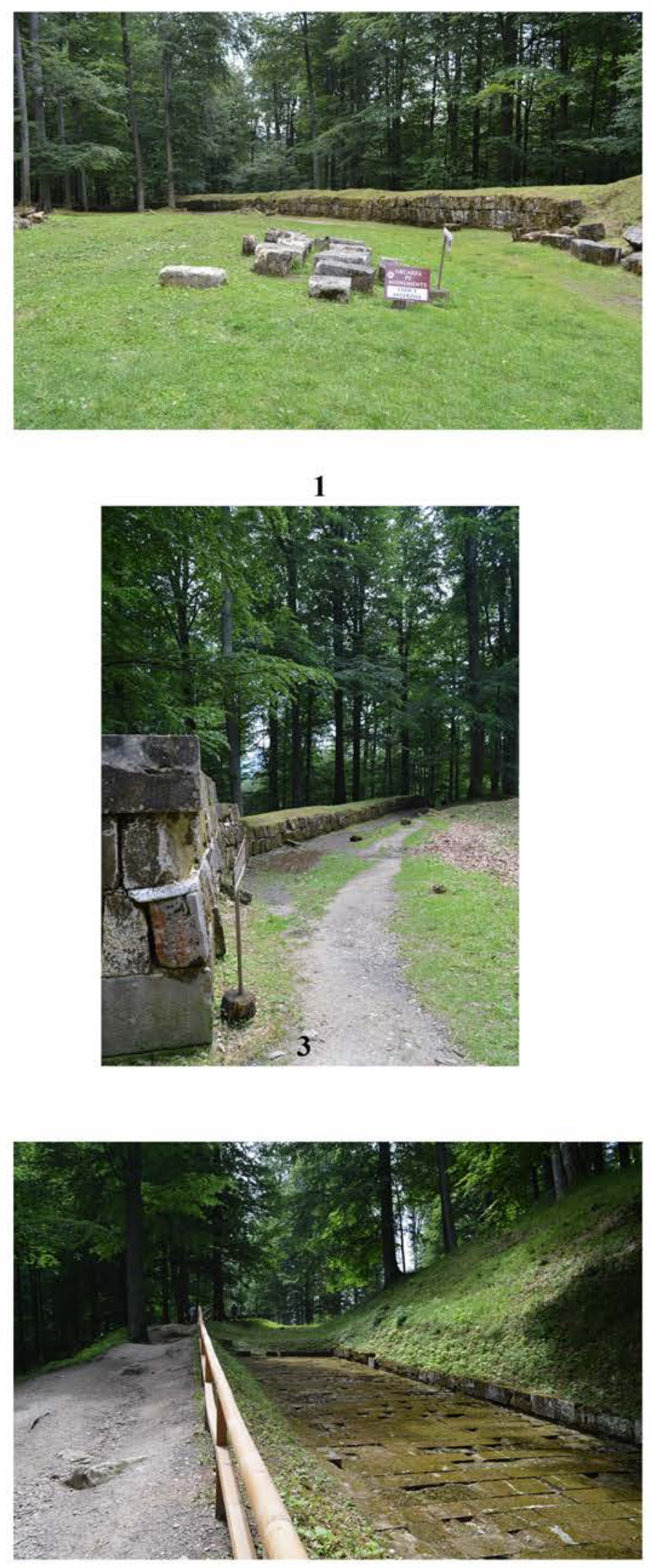

5

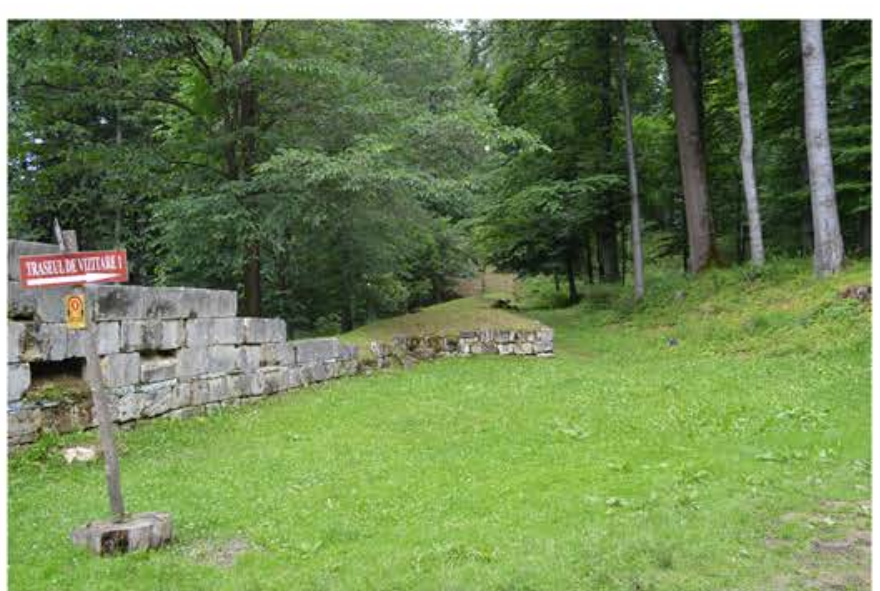

2

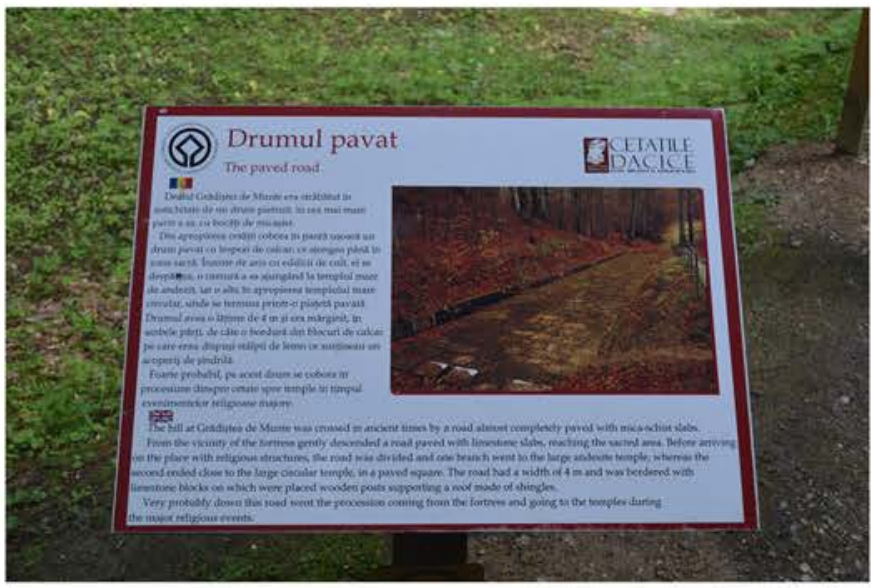

4

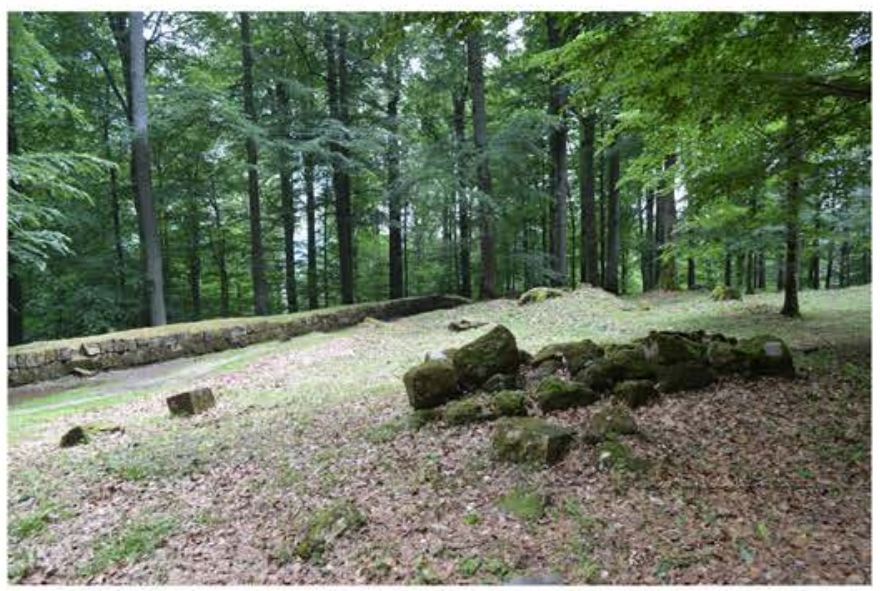

6

PI. 22. Fortress wall (1-3, 6), explanatory panel $(\mathbf{4})$ and paved road (5) from Sarmizegetusa Regia (photoVitalie Bârcă, 2018). 


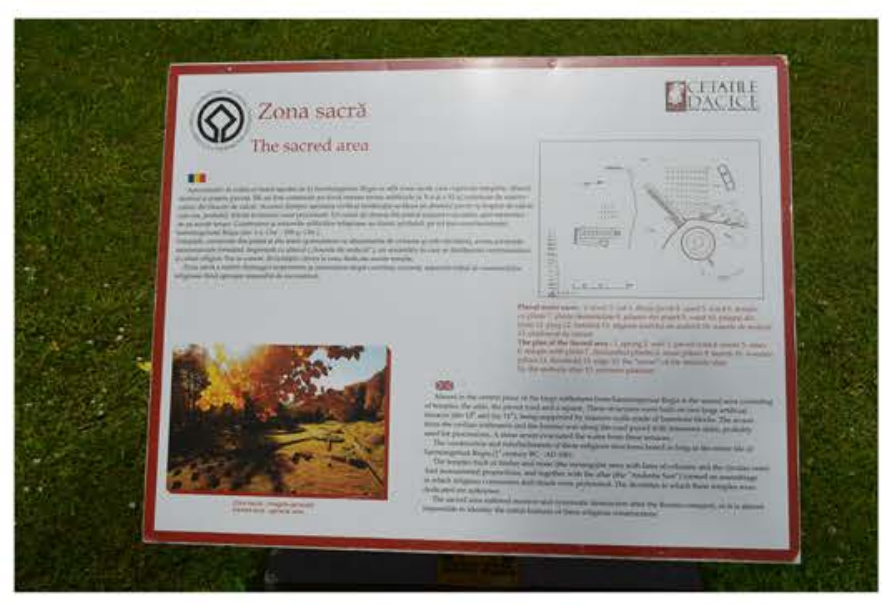

1

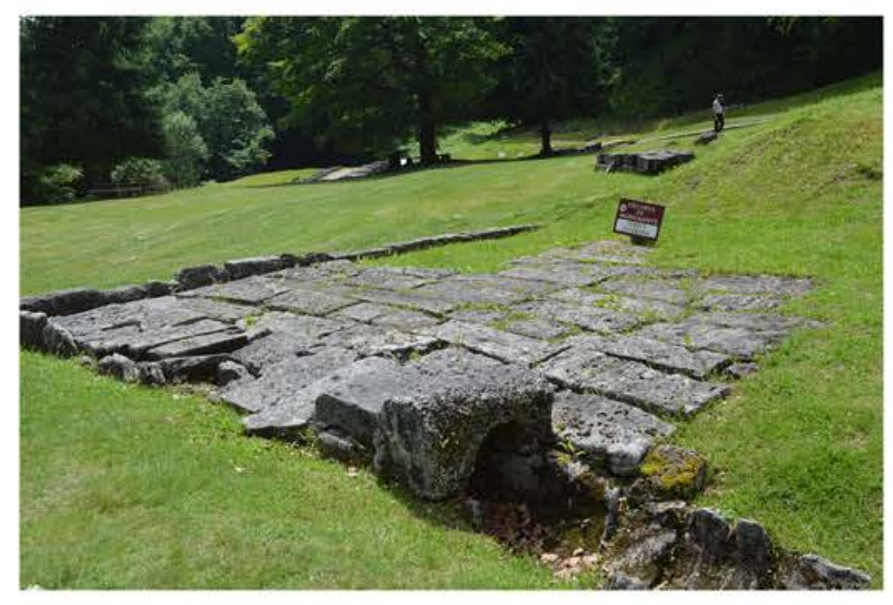

3

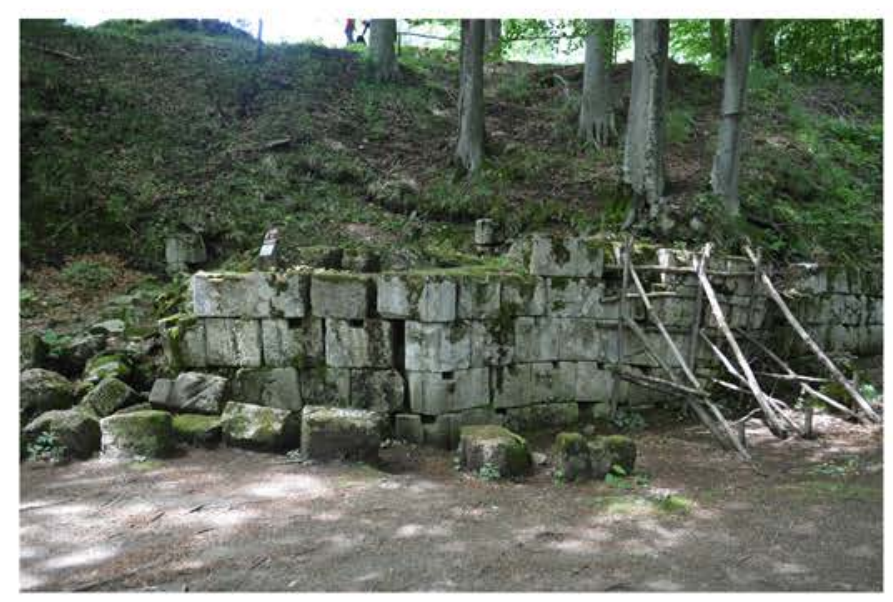

5

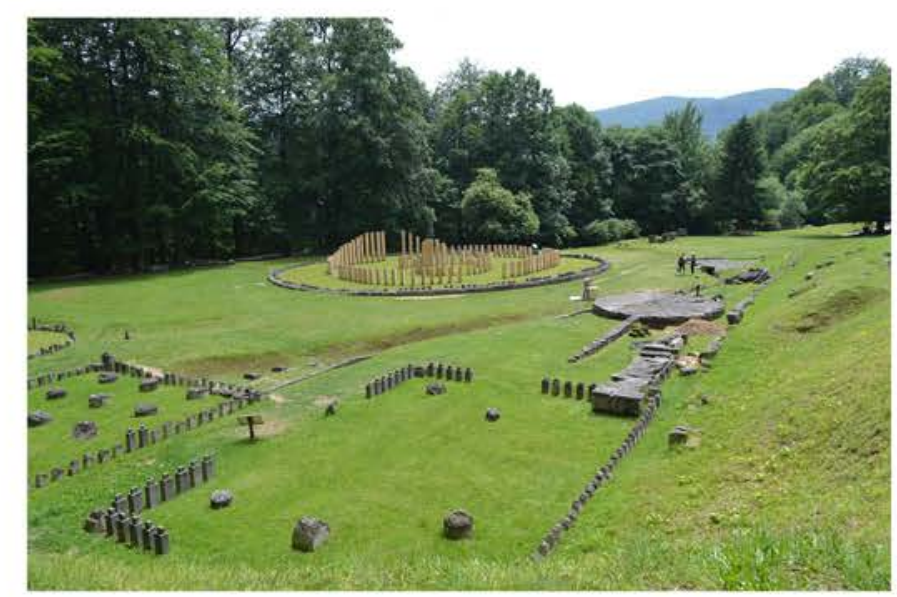

2

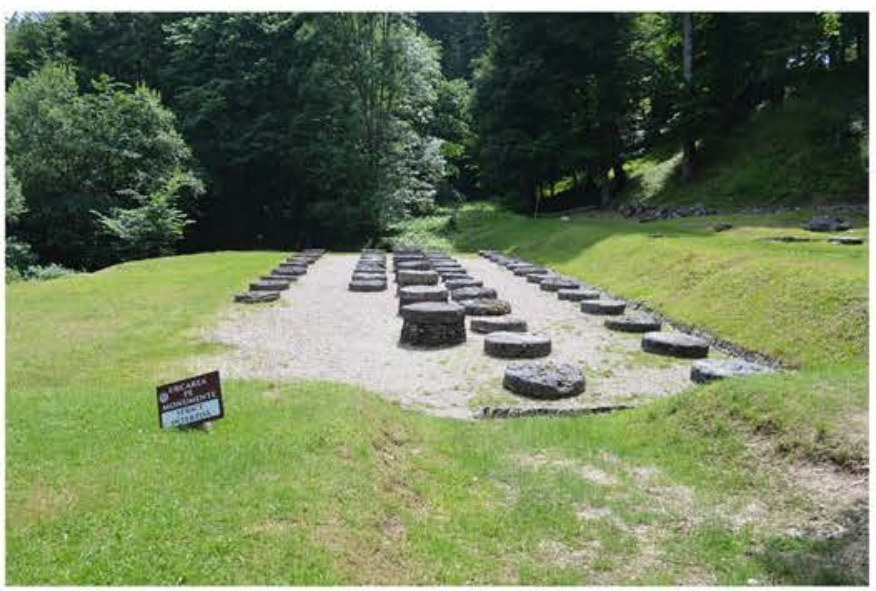

4

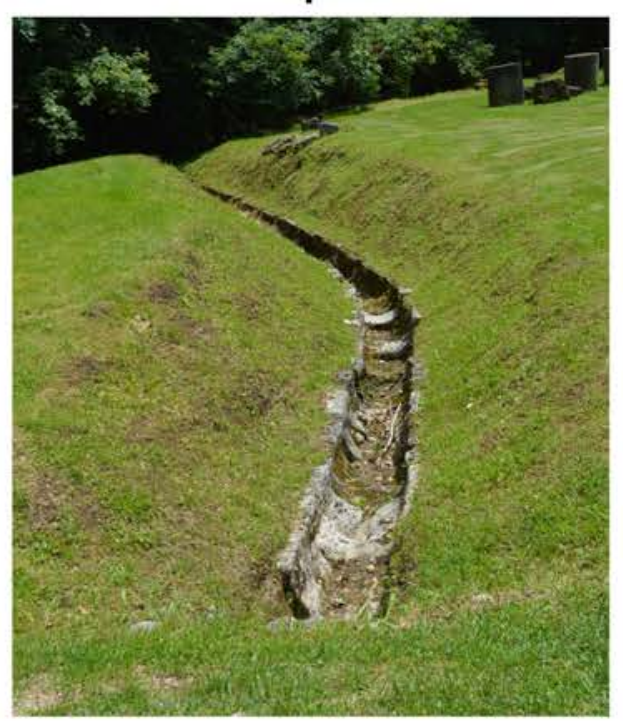

6

Pl. 23. Sarmizegetusa Regia. Explanatory panel (1), images of the sacred area (2), paved road (3); large limestone temple on terrace XI (4); pentagonal tower (5); channel of limestone elements on terrace XI (6) (photo Vitalie Bârcă, 2018). 


\section{Studies}

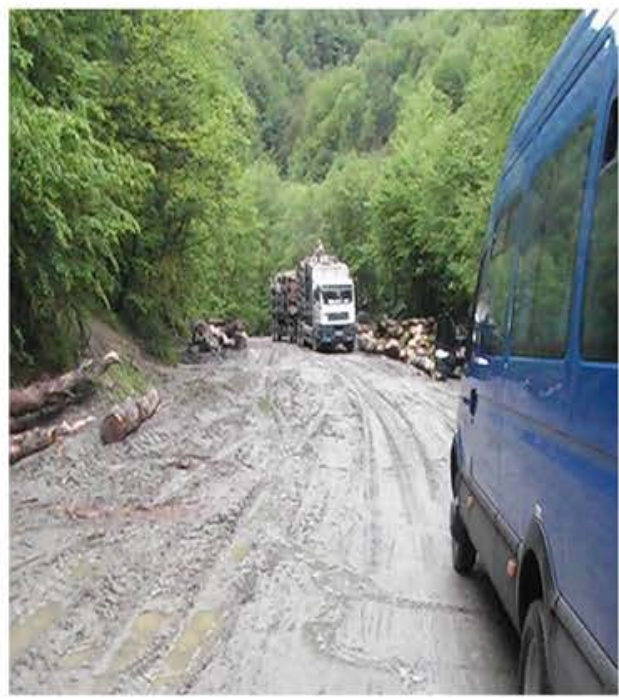

1

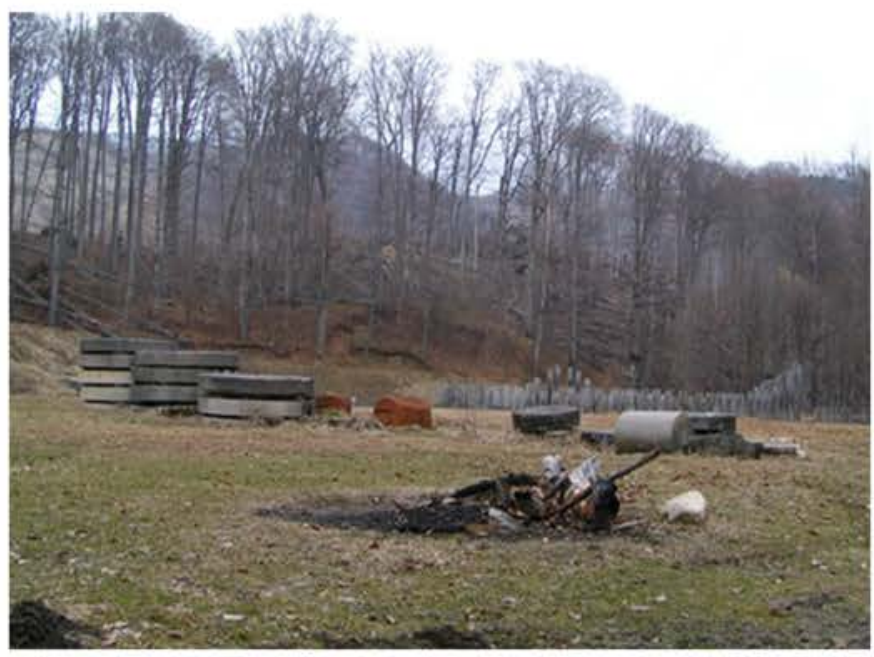

3

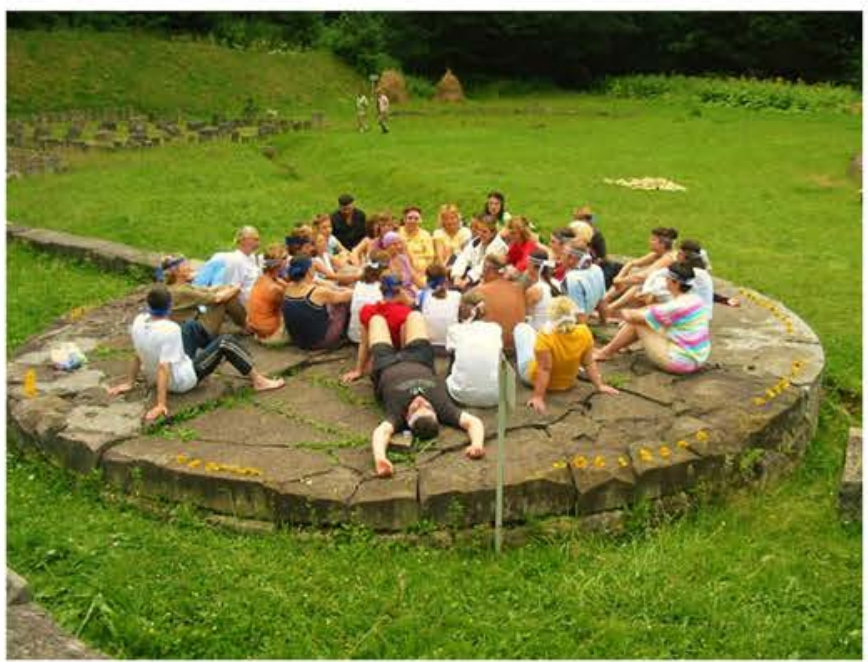

5

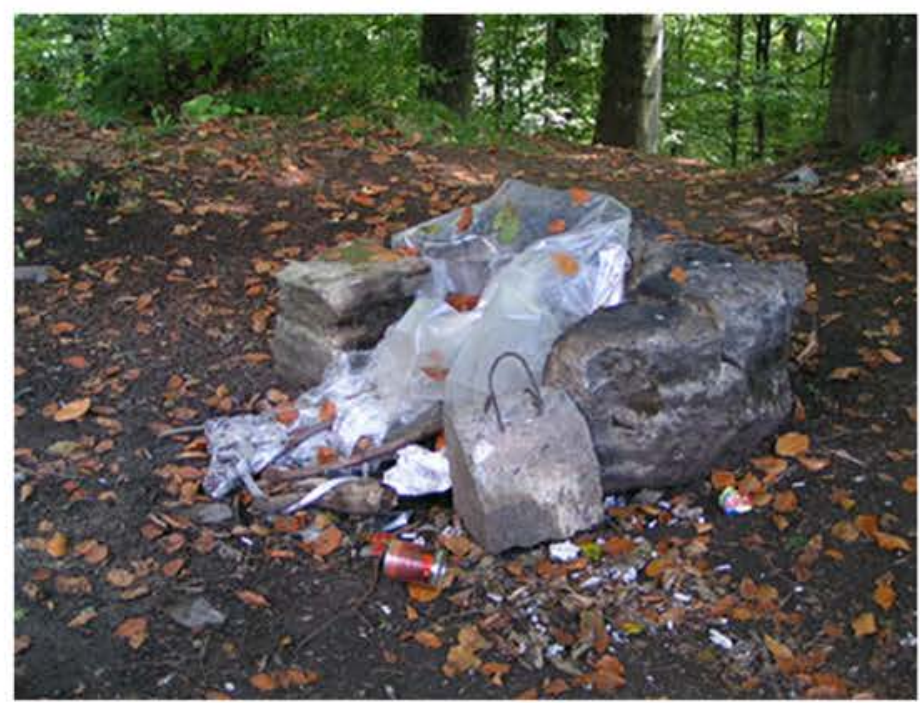

2

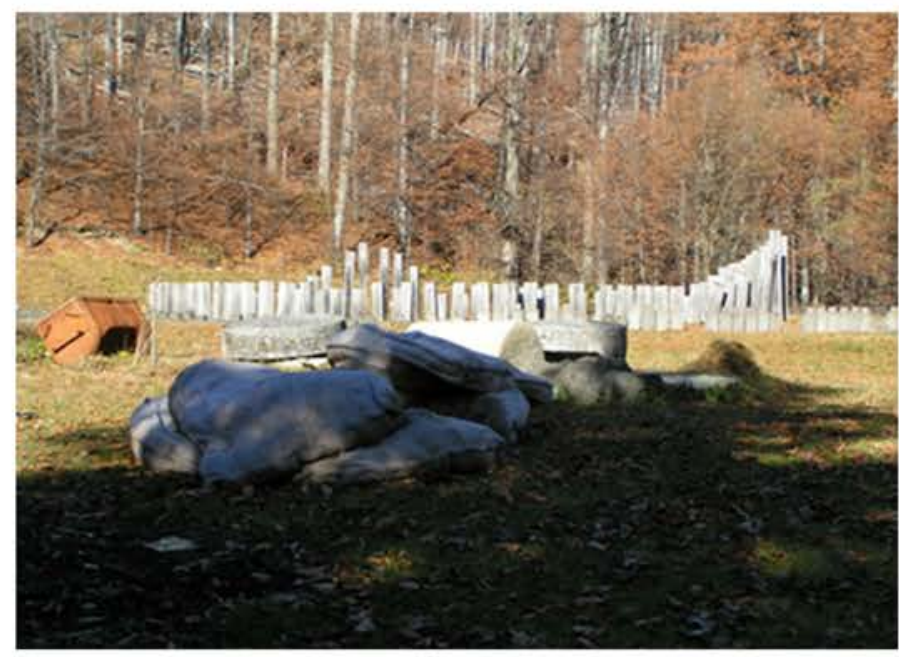

4

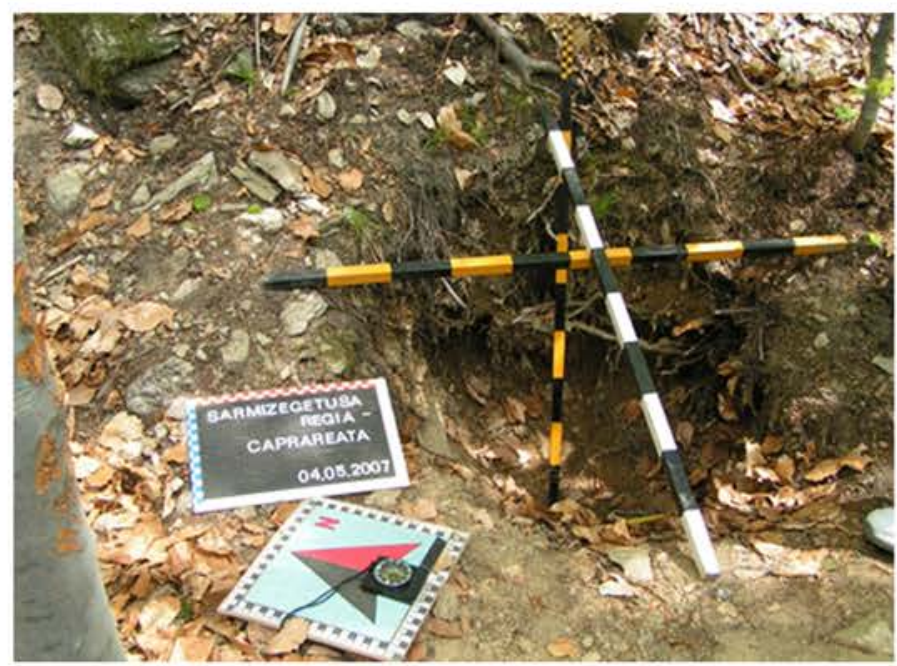

6

Pl. 24. Sarmizegetusa Regiaprior its take over under the administration of the County Council of Hunedoara.Access road to Sarmizegetusa Regia prior modernising (1); discouraging view and trash left by tourists (2-4); group with spiritual concerns on the andesite altar (5); vandalising and archaeological poaching actions (6) (photo Sorin Adrian Vasilescu). 

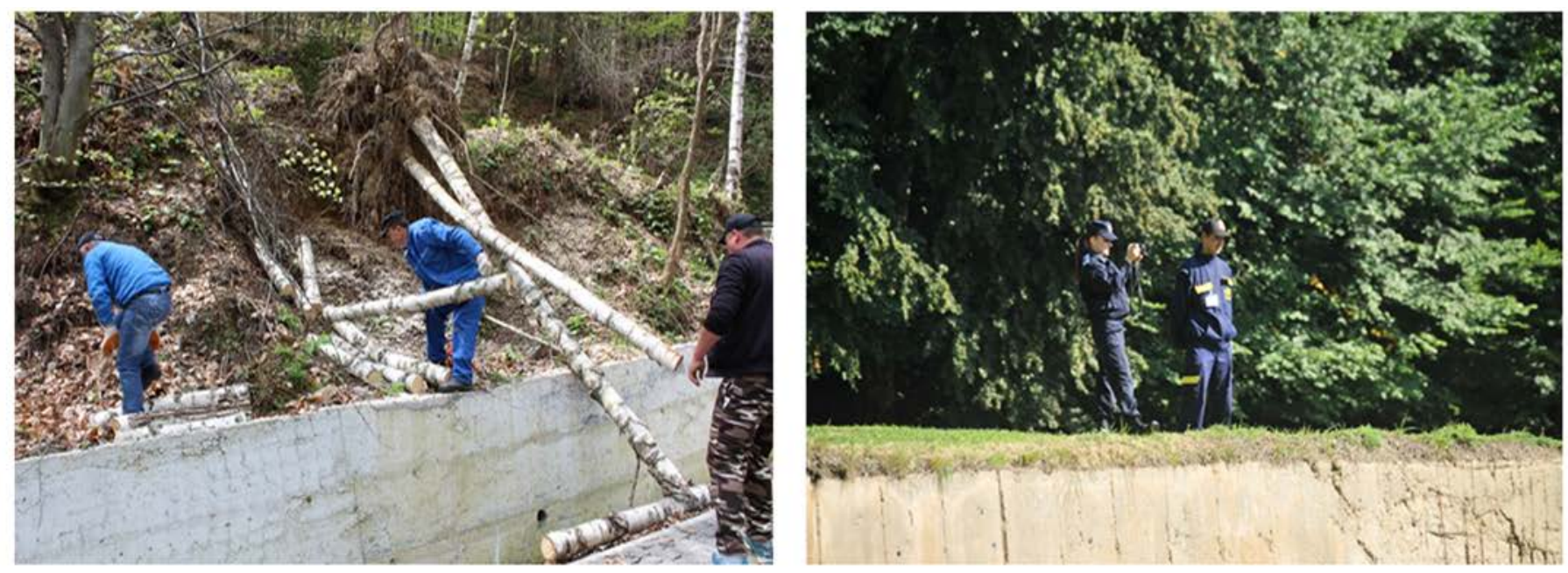

1

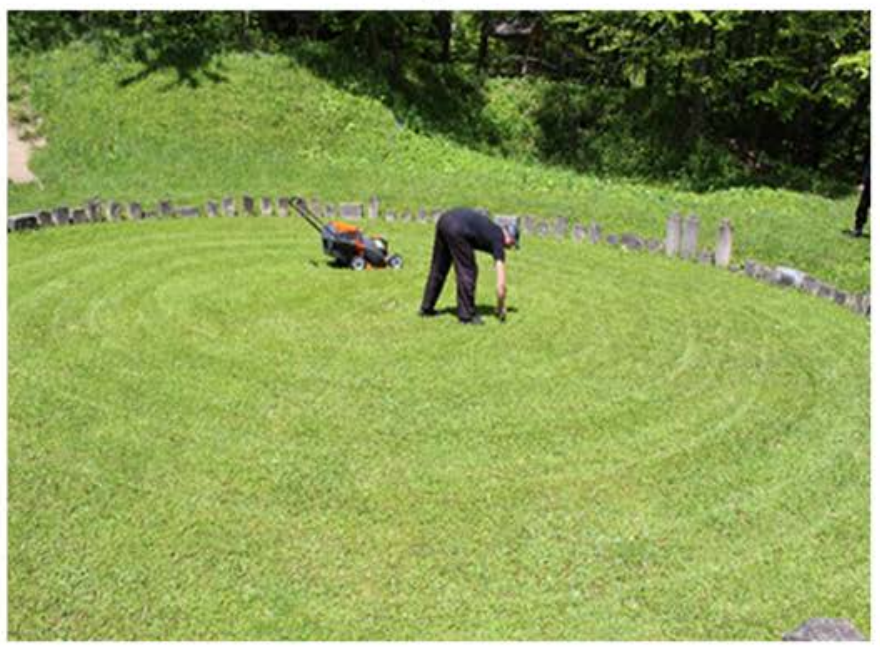

3

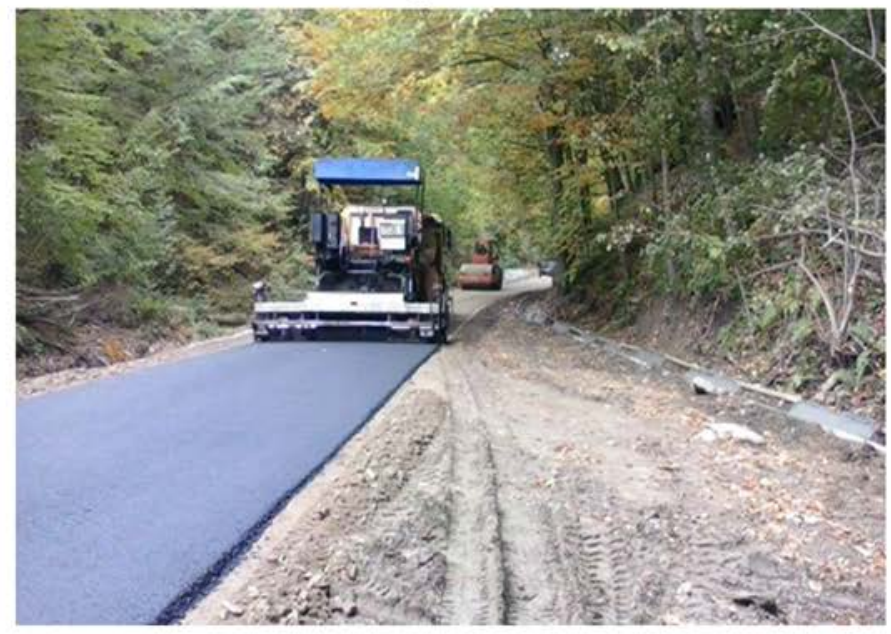

2

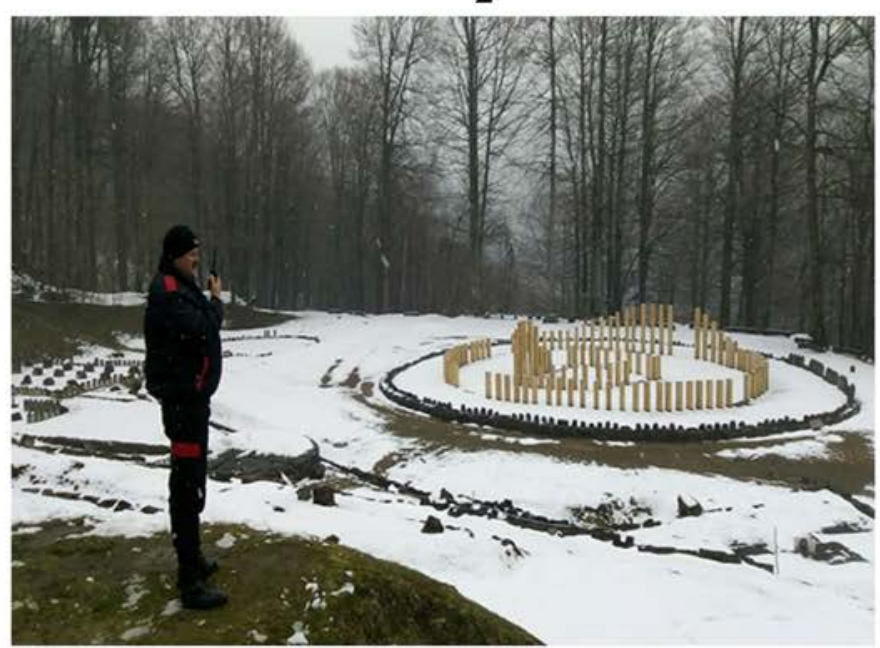

4

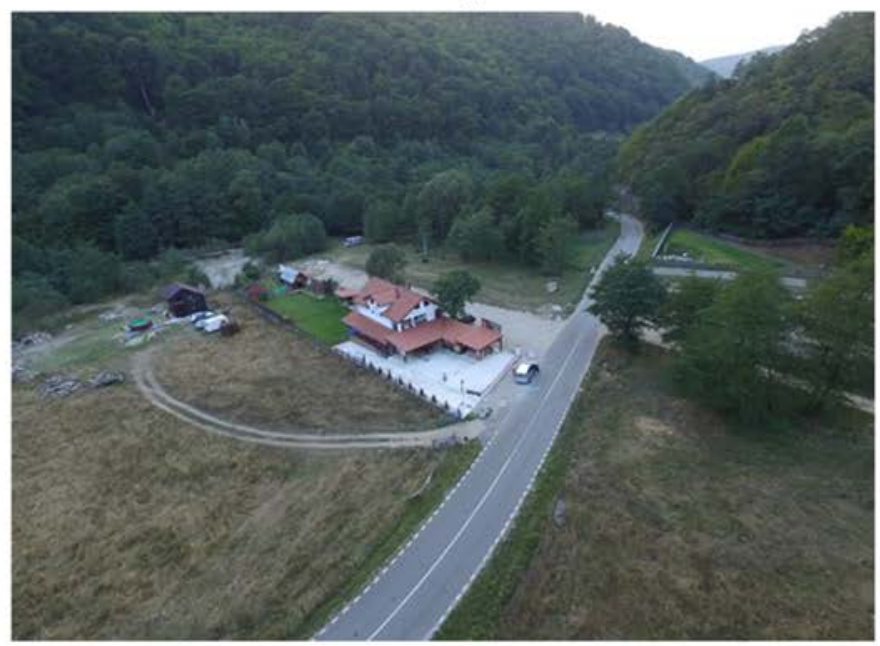

Pl. 25. Sarmizegetusa Regia. Trees' cutting in the managed perimeter (1); ensuring the quiet and public order by the Romanian Gendarmerie (2); maintenance and toiletry works of the green spaces in the sacred area (3); surveillance/security of the site by the private security company (4); modernising and asphalting the road leading to Sarmizegetusa (5); aerial view of the modernised road (6) (photo Sorin Adrian Vasilescu). 


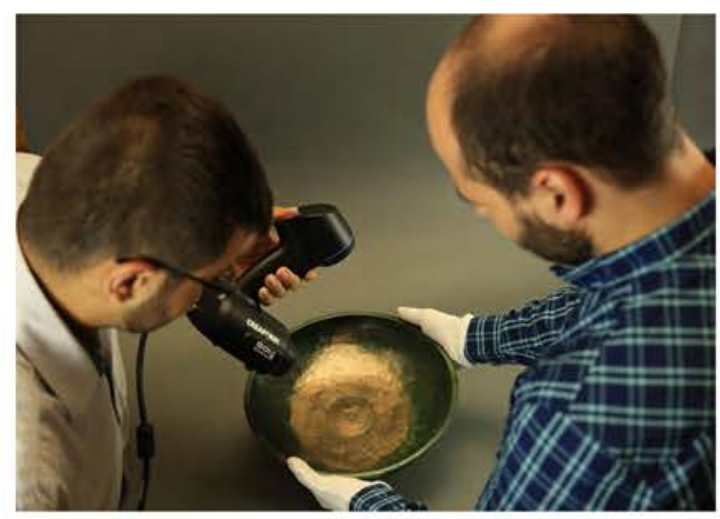

1

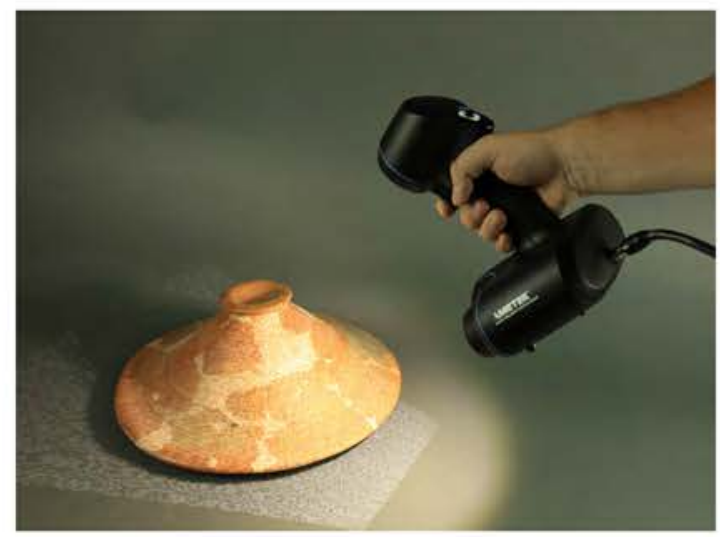

2

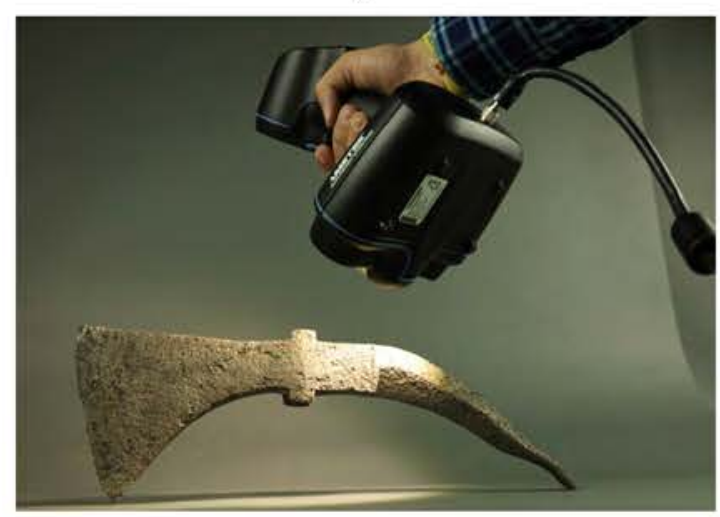

3

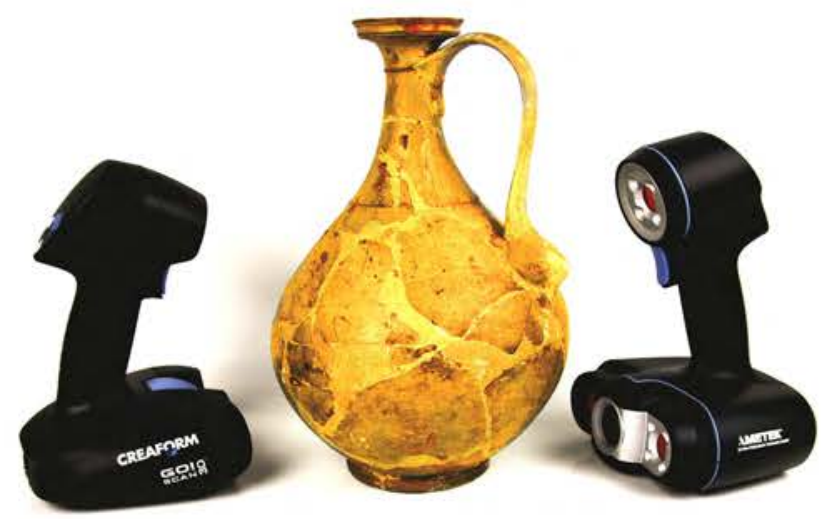

4

PI. 26. Aspects from during the scanning of the artefacts (1-3); type of devices used to scan the artefacts (4) (after NEAMȚU/ FLOREA/GHEORGHIU/BODÓ 2016). 


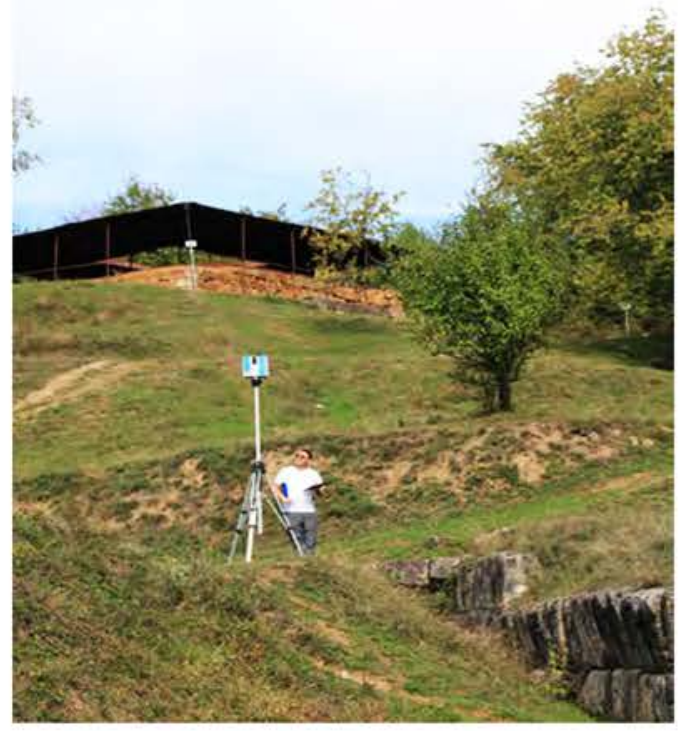

1

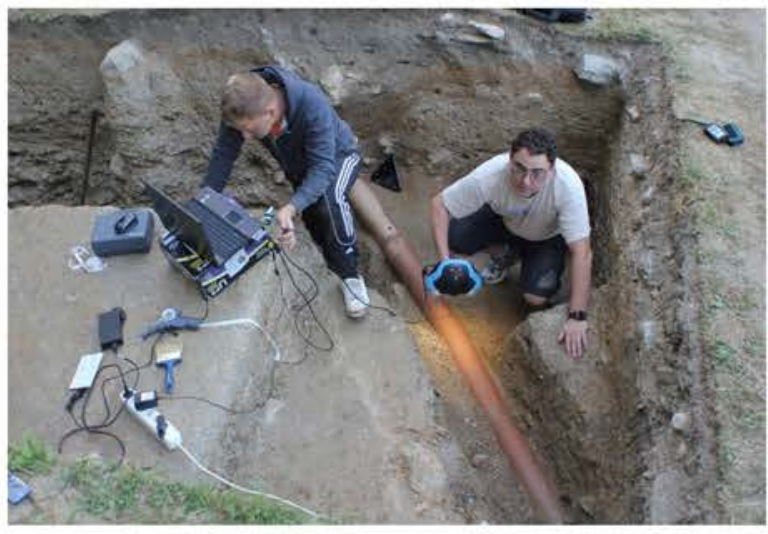

3

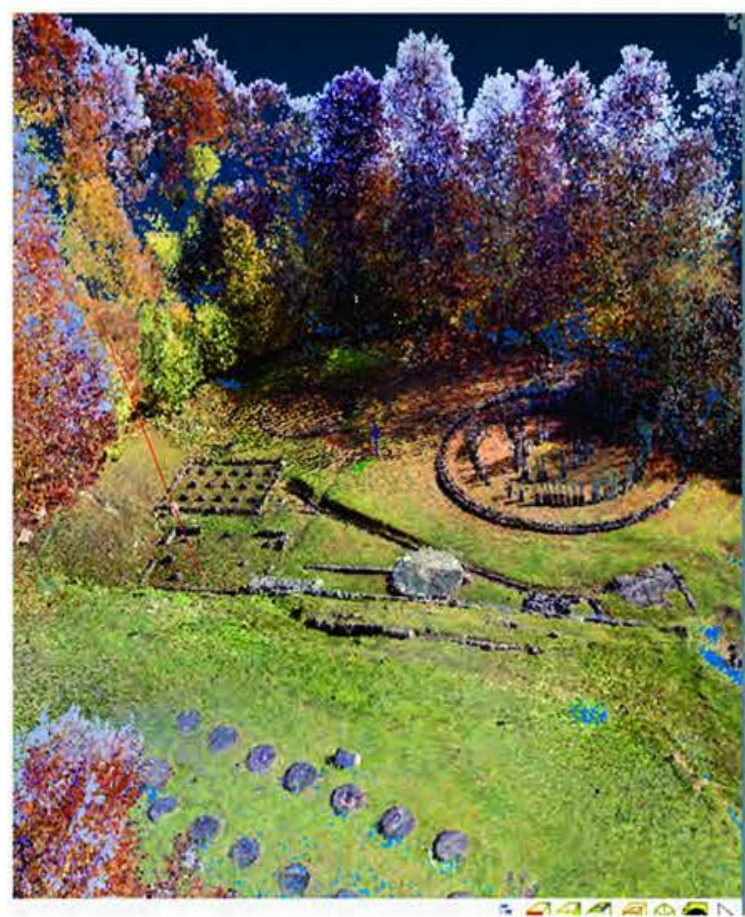

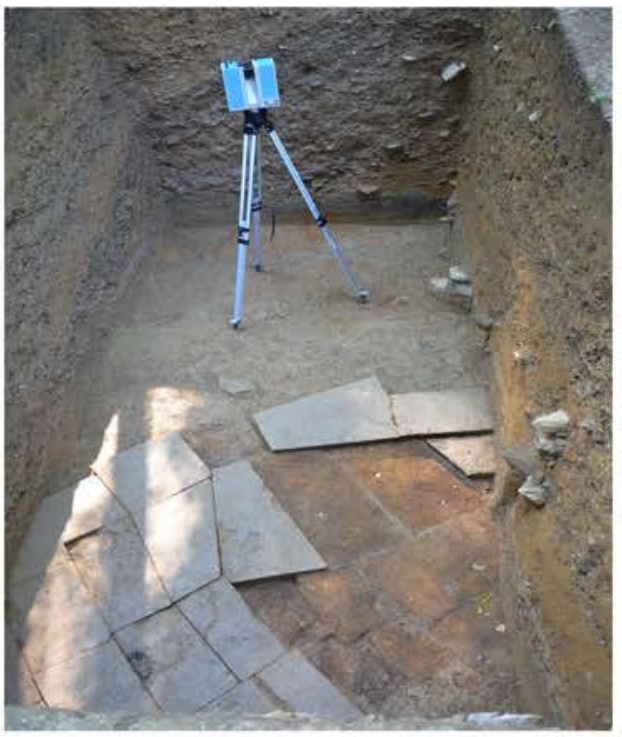

2

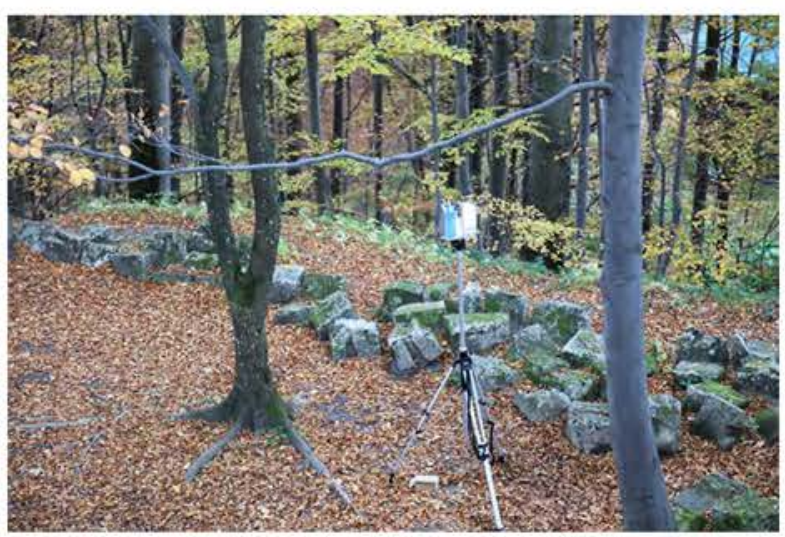

4

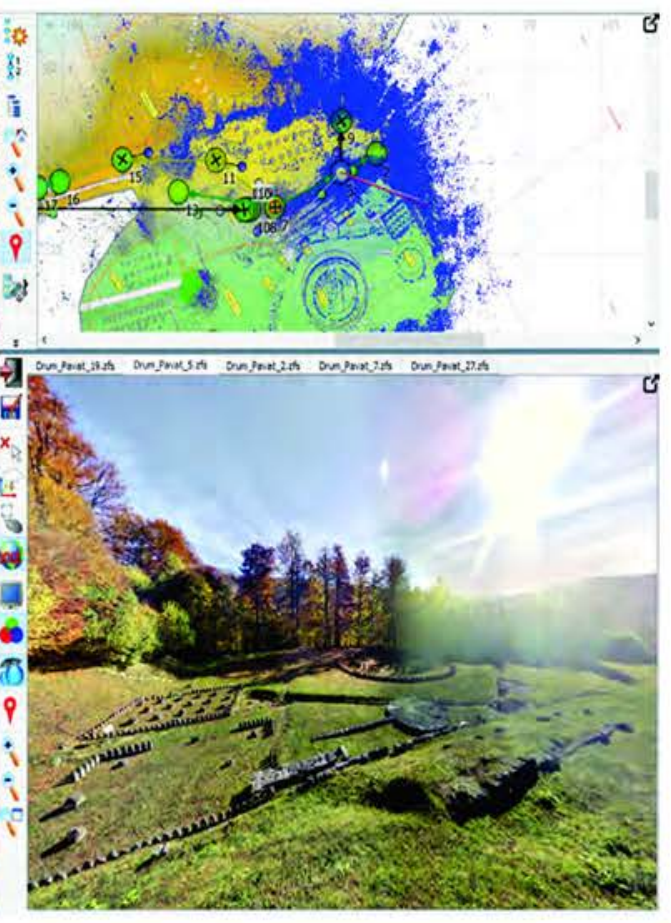

PI. 27. Aspects from during the scanning of the monuments (1-4); a stage in the process of processing data resulted from the monuments' scan (5) (1, 4-5 - after NEAMȚU/FLOREA/GHEORGHIU/BODÓ 2016; 2-3 - photo Răzvan Mateescu, 2018). 


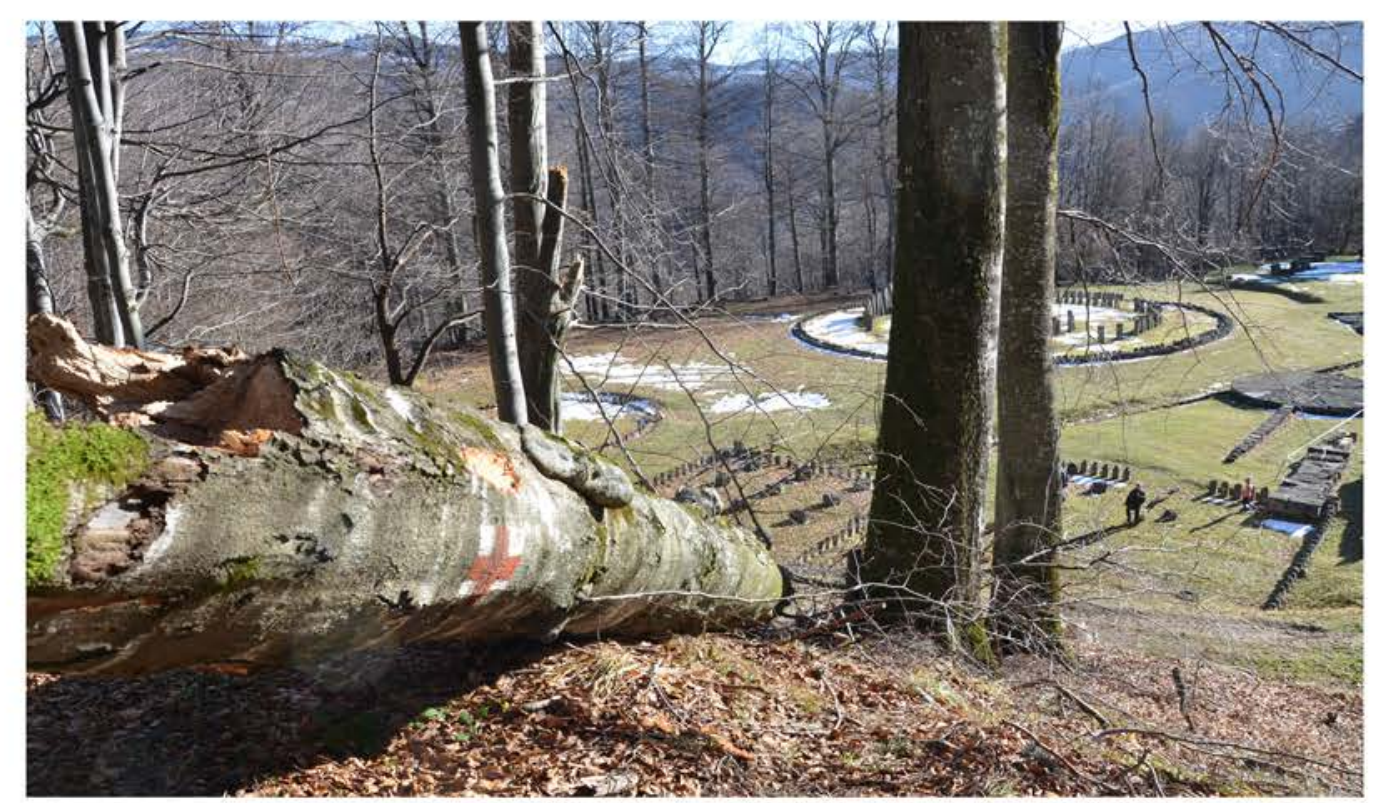

1

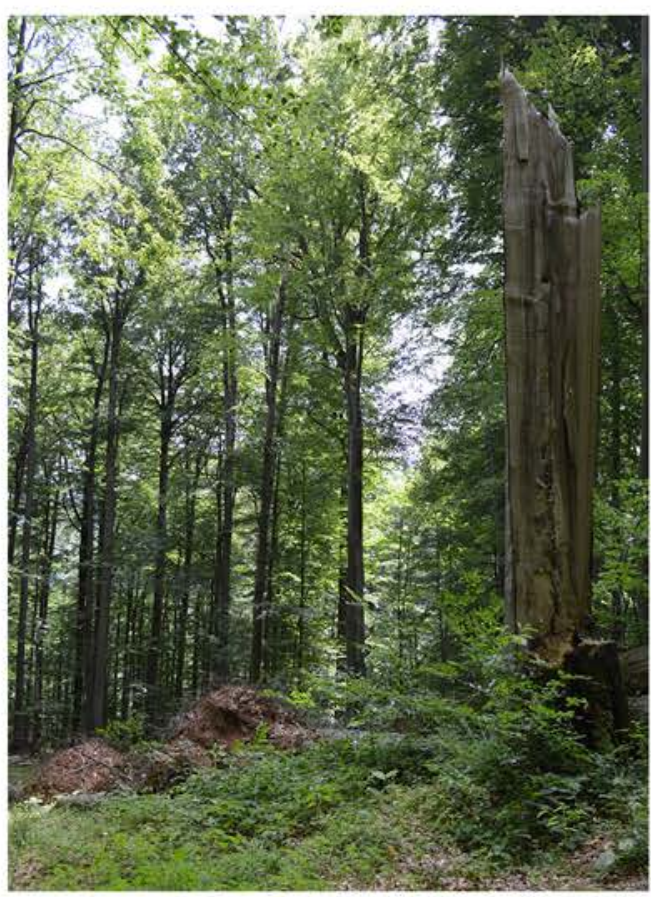

2

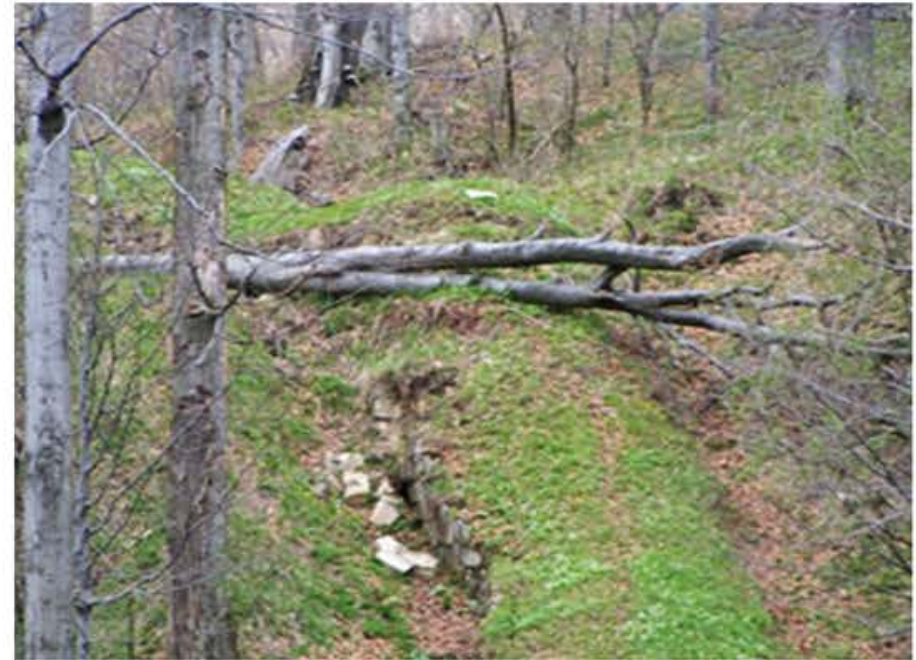

Pl. 28. 1-3. Fallen trees (photo Răzvan Mateescu (1), Vitalie Bârcă (2), Sorin Adrian Vasilescu (3). 